Historic, Archive Document

Do not assume content reflects current scientific knowledge, policies, or practices. 



\title{
PRICE LIST SPRING 1929
}

\section{Henry Kohankie}

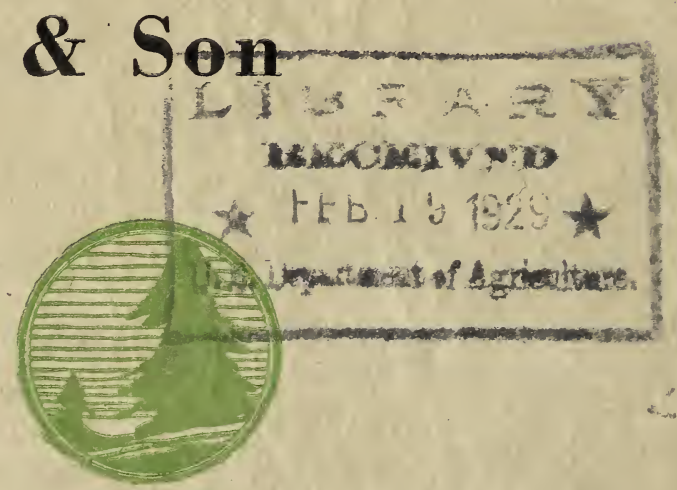

Trees, Shrubs, Evergreens, Vines, Roses, Herbaceous Perennials

\section{PAINESVILLE, OHIO}

Thirty Miles East of Cleveland

\author{
Tel. Main 137
}





\section{PRICE LIST HENRY KOHANKIE \& SON Spring 1929}

We offer herein a complete list of hardy ornamental nursery stock. Our nursery of five hundred acres affords material to meet practically every need in landscape development. Stock is well grown and supplied with a fibrous root system which is of vital importance in the success of a planting.

All material will be freshly dug. We maintain no storage cellars since the superiority of freshly dug stock is recognized generally.

With few exceptions, the plant names used conform to "Standardized Plant Names" as adopted by the Joint Committee on Horticultural Nomenclature. 



\section{Please Read Carefully!}

CONDITIONS OF SALE

Stock will be supplied at prices named herein as follows: Five of any one variety at ten rate; twenty-five of any one variety at hundred rate. Prices do not include packing. A charge for the actual cost of the boxes and material used in baling will be made.

Stock specially selected by customers at the nursery will be charged according to its value.

We give no warranty, expressed or implied, as to quality, description, productiveness, or any other matter of any nursery stock that we sell.

We do not guarantee our stock to live and no allowance will be made for plants that fail. Our methods of handling and packing stock are modern and goods will be in good condition and well packed when they leave our grounds. Our responsibility ends upon delivery to carriers. If goods suffer through delay in transit, claim should at once be made on transportation company.

All claims for errors must be made within six days after receipt of goods, or positively will not be considered.

Unknown correspondents who wish to open an account will please give us references and allow us sufficient time to investigate same. Otherwise, cash must accompany order. If goods are desired C. O. D., the order must be accompanied by one third of the amount to guarantee acceptance.

Shipping facilities-We can make direct shipment over the N. Y. C. R. R.; B. \&. O. R. R.; N. Y. C. \& St. L. R. R.; American Railway Express and Electric Package. A siding to our packing house direct from the main line of the New York Central railroad enables us to handle stock with a minimum of exposure.

Auto Truck Delivery-We are in a position to make deliveries by auto truck to points within seventy-five miles of Painesville. Charges are made according to the size of truck required and the distance. 



\section{Evergreen Trees}

In this department our stock is thrifty and fibrously rooted, having been several times transplanted. Failure to frequently transplant results in a coarse root system; an evergreen so grown, regardless of how symmetrical and attractive the top may be, is almost certain to give poor results. Prices include lifting the plants with a ball of earth and sewing in burlap as an extra precaution that the plants may arrive in the best of condition.

Abies arizonica. Cork Fir.

each per 10 per 100

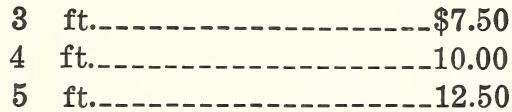

balsamea. Balsam Fir.

3 ft.-_-_-_-_-_- 3.75

4 ft._-_- 5.00

5 ft._.-. 7.50

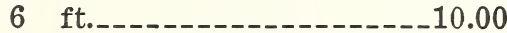

7 ft._._-_-_-_._- 12.50

8 ft._-_._-_._-_._- 15.00

9 ft.

concolor. White Fir.

2 ft._-_-_-_-_-_-_-_-_ 8.00

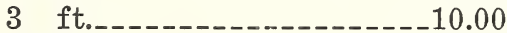

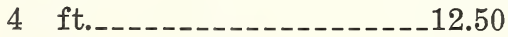

5 ft._._-_._- 15.00

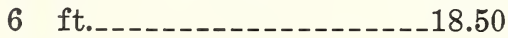

7 ft._._._.

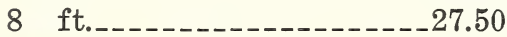

concolor violacea. Purplecone White Fir.

3 ft.-_-_-_-_-_-_-_-_-_12.50

homolepis. Nikko Fir.

4 ft.

5 ft._-_-_-_- 15.00

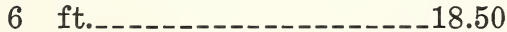

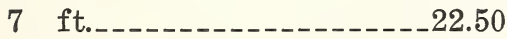

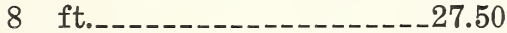

9 ft._-_-___-_-_-_-_-_32.50

nordmanniana. Nordmann Fir.

$2 \mathrm{ft.}$

3 ft._-_-_-_-_-_-_ 10.00

4 ft._-_._-_._- 12.50

5 ft._-_-_-_-_-_-_-_-_-_-_15.00 
Abies veitchi. Veitch Fir.

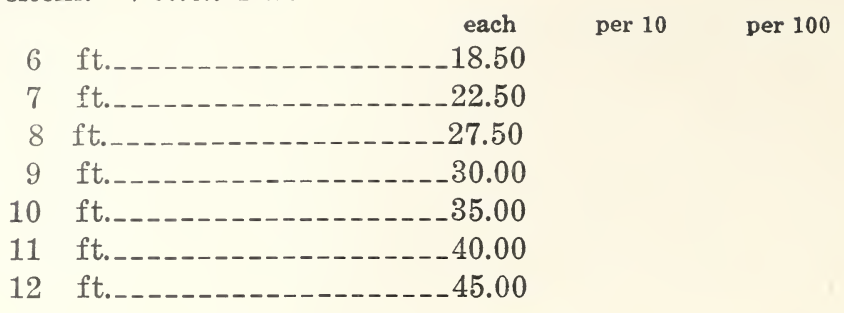

Biota orientalis. (See Thuja.)

Cedrus libani. Cedar of Lebanon.

\begin{tabular}{|c|c|}
\hline \multirow{2}{*}{$\begin{array}{r}8.00 \\
10.00\end{array}$} & \\
\hline & \\
\hline ft._-_- & \\
\hline 7 ft._-_- & \\
\hline
\end{tabular}

Cephalotaxus fortunei. Chinese Plumyew.

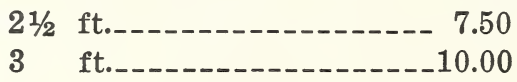

Chamaecyparis lawsoniana. Lawson Cypress.

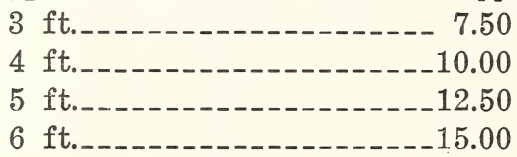

lawsoniana pendula. Weeping Lawson Cypress.

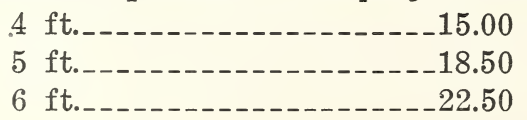

nootkatensis. Nootka Cypress.

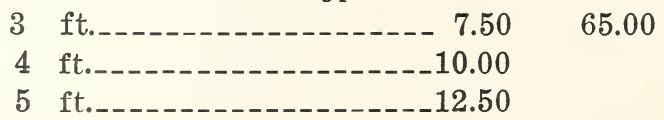

Juniperus chinensis. Chinese Juniper.

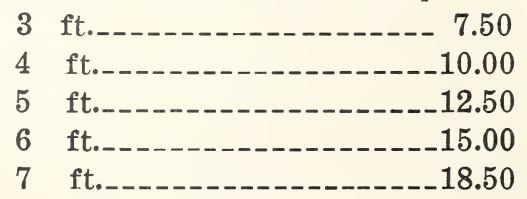


Juniperus chinensis albovariegata.

$$
\text { each }
$$

Whiteleaf Chinese Juniper.

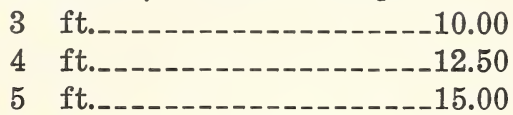

chinensis globosa. Globe Chinese Juniper.

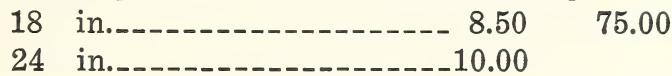

chinensis neaboriensis. Conical Chinese Juniper.

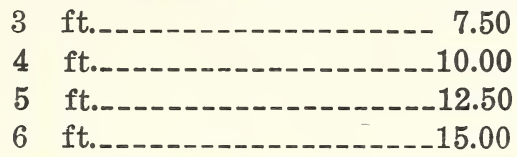

chinensis pfitzeriana. Pfitzer's Juniper.

2 to $2 \frac{1}{2} \mathrm{ft}$. spread__._-_ $6.50 \quad 60.00$

$21 / 2$ to 3 ft. spread._._.- $7.50 \quad 70.00$

3 to $31 / 2 \mathrm{ft}$. spread.--_-_ $10.00 \quad 95.00$

$31 / 2$ to 4 ft. spread-_--- 15.00

4 to $4 \frac{1}{2}$ ft. spread___-_ 20.00

communis. Common Juniper.

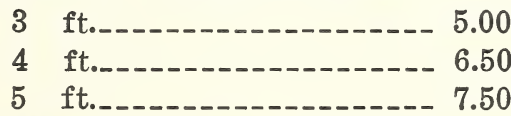

45.00

communis depressa. Prostrate Juniper.

18 to 24 in. spread__._-_ $4.50 \quad 40.00$

24 to 30 in. spread____- $5.00 \quad 45.00$

$2 \frac{1}{2}$ to $3 \mathrm{ft}$. spread_.._-_- $6.50 \quad 50.00$

3 to $4 \mathrm{ft}$. spread._...- 7.50

4 to $5 \mathrm{ft}$. spread__._.- 10.00

communis depressa aurea.

Golden Prostrate Juniper.

18 to 24 in. spread.--- $4.50 \quad 40.00$

24 to 30 in. spread_-- $5.00 \quad 45.00$

$21 / 2$ to 3 ft. spread__-_ $6.50 \quad 50.00$

3 to $31 / 2 \mathrm{ft}$. spread_-_- $7.50 \quad 65.00$

$31 / 2$ to $4 \mathrm{ft}$ spread__-_- $10.00 \quad 75.00$

communis hibernica. Irish Juniper.

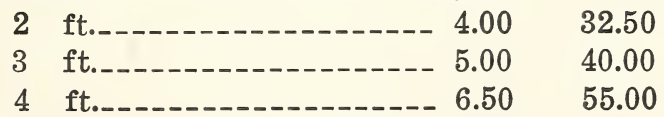

communis kraccovica. Polish Juniper.

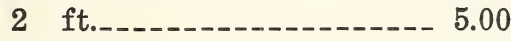

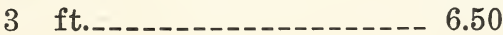


Juniperus communis suecica. Swedish Juniper.

$$
\text { each per } 10 \text { per } 100
$$

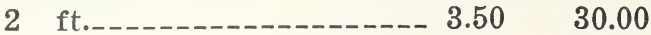

$$
\begin{aligned}
& 3 \text { ft._-_-_-_-_-_-_-_ } 4.00 \quad 35.00
\end{aligned}
$$

communis suecica nana. Dwarf Swedish Juniper.

$$
2 \text { ft.--_-_-_-_-_-_-_-_-- } 4.00 \quad 35.00
$$

excelsa. Greek Juniper.

$$
\begin{aligned}
& 3 \text { ft._-_-_-_-_-_-_----- } 5.00 \quad 47.50 \\
& 4 \text { ft._-_-_-_-_-_-_- } 6.50 \\
& 5 \text { ft._-_-_-_-_- } 10.00
\end{aligned}
$$

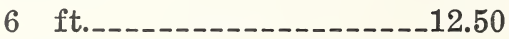

excelsa stricta. Spiny Greek Juniper.

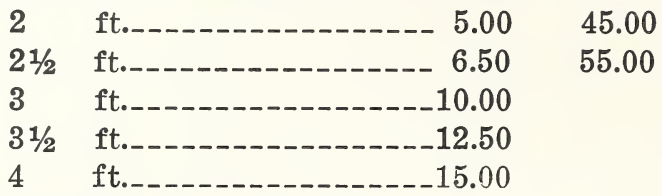

horizontalis. Creeping Juniper.

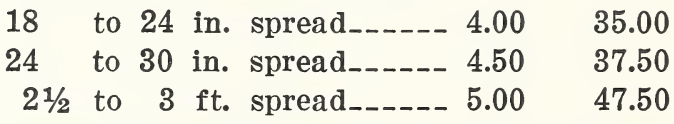

horizontalis glauca. Blue Creeping Juniper.

$\begin{array}{cllll}18 & \text { to } 24 & \text { in. spread_--- } & 4.50 & 40.00 \\ 24 & \text { to } 30 & \text { in. spread_--- } & 5.00 & 45.00 \\ 21 / 2 & \text { to } 3 & \text { ft. spread_--- } & 6.00 & 50.00 \\ 3 & \text { to } 31 / 2 & \text { ft. } \text { spread_--- } 7.50 & 60.00\end{array}$

japonica. Japanese Juniper.

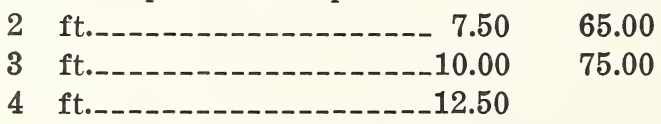

japonica aurea. Golden Japanese Juniper.

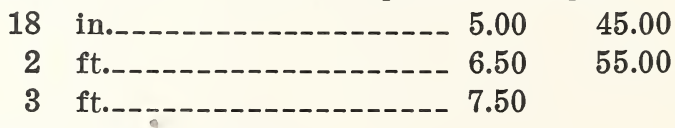

sabina. Savin Juniper.

$\begin{array}{llllll}2 & \text { to } 21 / 2 & \mathrm{ft} . & \text { spread_-_-- } 5.00 & 45.00 & 400.00 \\ 21 / 2 & \text { to } 3 & \mathrm{ft} . & \text { spread_-_-- } 6.50 & 55.00 & \\ 3 & \text { to } 31 / 2 & \mathrm{ft} . & \text { spread_-_-- } 7.50 & & \\ 31 / 2 & \text { to } 4 & \text { ft. } \text { spread_-_-_10.00 } & \end{array}$

sabina tamariscifolia. Tamarix Savin.

18 to $24 \mathrm{in}$. spread__-_-_-- 5.00

24 to 30 in. spread__-_-_-- 7.50 


\section{Juniperus}

scopulorum. Colorado Juniper.

\begin{tabular}{|c|c|}
\hline 3 ft._-_- 6.50 & 55.00 \\
\hline ft._- 9.00 & 75.00 \\
\hline$\ldots 11.00$ & 90.00 \\
\hline-12.50 & 110.00 \\
\hline ft. & \\
\hline
\end{tabular}

squamata. Japanese Trailing Juniper.

2 to $2 \frac{1}{2} \mathrm{ft}$. spread_____-_- 6.50

virginiana. Red Cedar.

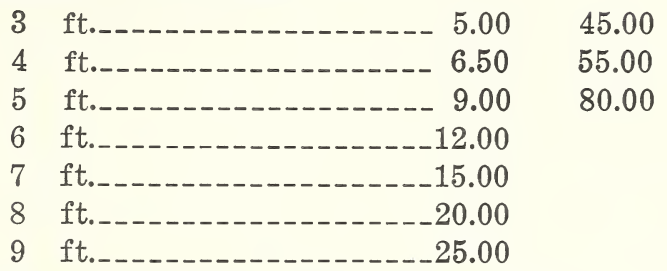

virginiana cannarti. Cannart Red Cedar.

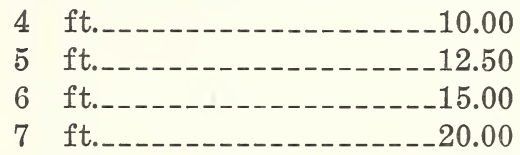

virginiana elegantissima. Goldtip Red Cedar.

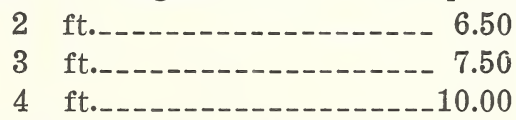

virginiana glauca. Silver Red Cedar.

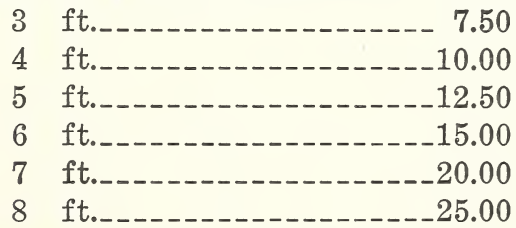

virginiana kosteri. Koster Red Cedar.

2 to $2 \frac{1}{2} \mathrm{ft}$. spread._._._ 7.50

$21 / 2$ to 3 ft. spread__._. 10.00

3 to $3 \frac{1}{2} \mathrm{ft}$. spread__._._- 12.50

$31 / 2$ to 4 ft. spread_-_-_- 15.00

virginiana schotti. Schott Red Cedar.

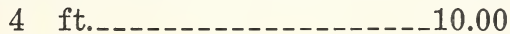

5 ft._._-_._- 12.50

$6 \mathrm{ft.}$.

7 ft._-_-_._- 20.00 
Picea alba. White Spruce.

$$
\text { each per } 10
$$

per 100

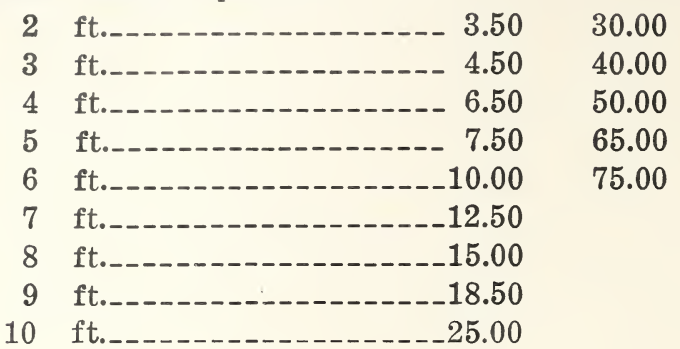

alcockiana. Alcock Spruce.

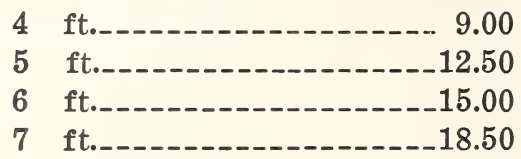

canadensis. Black Hills Spruce.

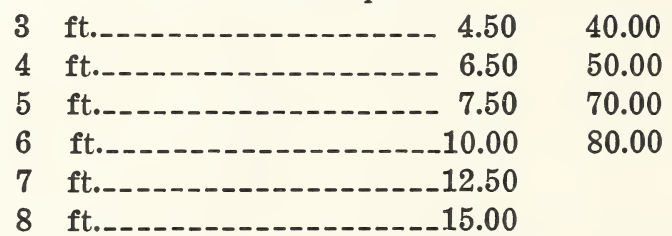

engelmanni. Englemann Spruce.

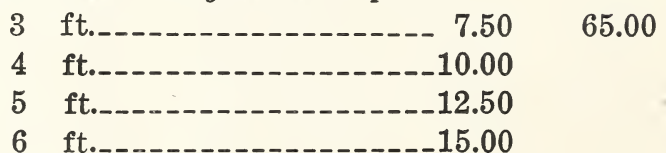

excelsa. Norway Spruce.

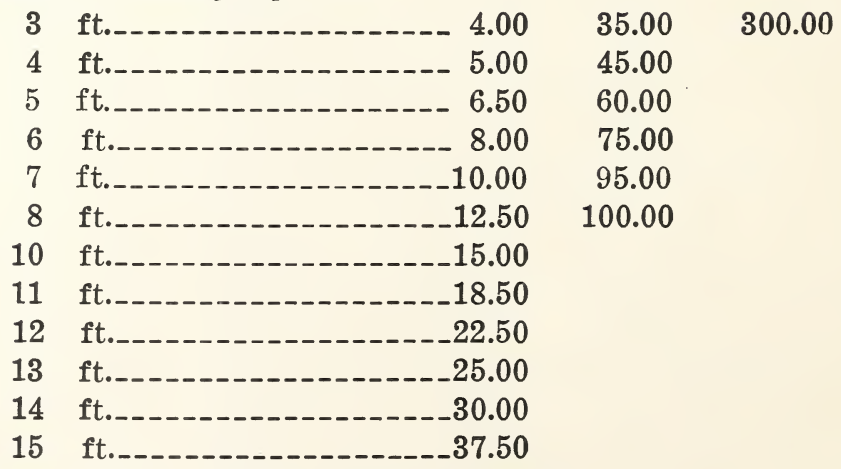

excelsa aurea. Golden Norway Spruce.

2 ft.-_-_-_-_-_-_-_-_-_-_-_10.00 


\section{Picea}

excelsa pendula. Weeping Spruce.

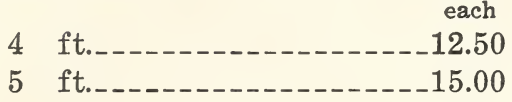

excelsa maxwelli. Maxwell Spruce.

18 to 24 in...... 10.00

24 to 30 in.... 12.50

excelsa nana compacta. Dwarf Spruce.

18 to 24 in.

24 to 30 in.......... 12.50

excelsa pygmea. Pygmy Norway Spruce.

15 to $18 \mathrm{in.}$

18 to 24 in.

excelsa remonti. Remont Spruce.

18 to 24 in.

24 to 30 in...... 12.50

mariana. Black Spruce.

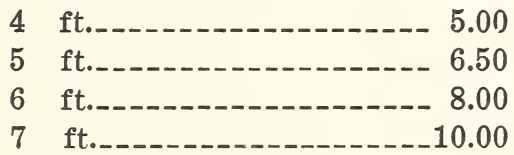

orientalis. Oriental Spruce.

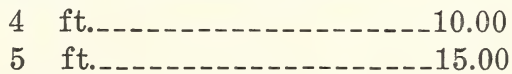

polita. Tigertail Spruce.

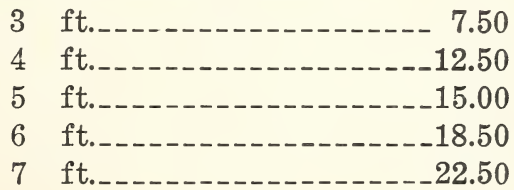

pungens. Colorado Spruce.

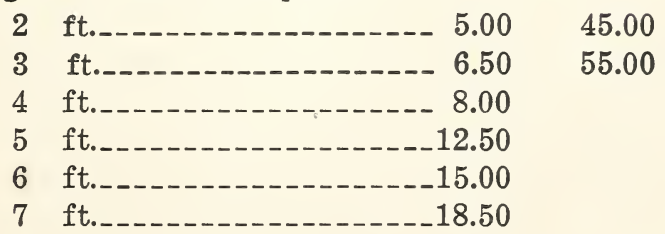




\section{Picea}

pungens glauca. Blue Colorado Spruce.

$\begin{array}{rrr} & \text { each } & \text { per } 10 \\ 3 & \mathrm{ft} . & \mathrm{ft} . \\ 4 & \mathrm{ft} . & \\ 5 & \mathrm{ft} . & \\ 6 & \mathrm{ft} . & \end{array}$

pungens kosteri. Koster Blue Spruce.

\begin{tabular}{|c|c|}
\hline & ft.-. \\
\hline & ft.-_-n-- \\
\hline & -18.50 \\
\hline & $\ldots-20.00$ \\
\hline & ft._- \\
\hline & ft._-_-_-_-_en \\
\hline & ft. \\
\hline & ft._-n- 45.00 \\
\hline & 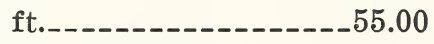 \\
\hline & ft. specimens_____ 70.00 \\
\hline & ft. specimens_-_--- 80.00 \\
\hline & ft. specimens_-_-_-_90.0 \\
\hline & ft. specimens \\
\hline
\end{tabular}

Pinus austriaca. (See Pinus Nigra.)

\section{banksiana. Jack Pine.}

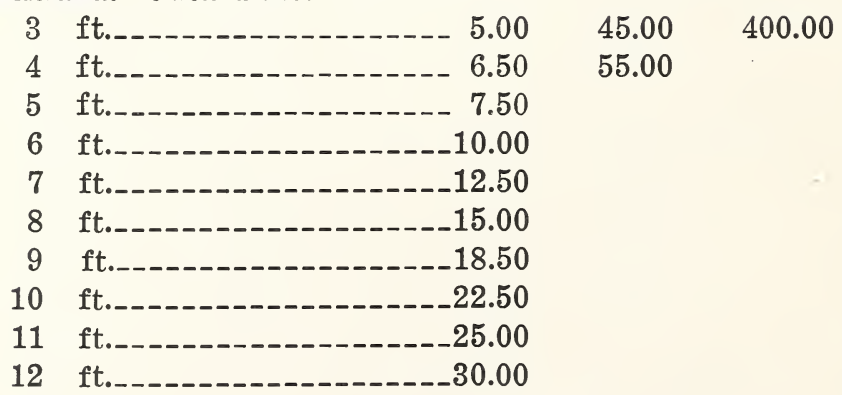

densiflora. Japanese Red Pine.

$6 \mathrm{ft.}$.

$7 \mathrm{ft.}$._- 15.00

$8 \mathrm{ft.}$.

9 ft._-_-_-_en 
Pinus.

$\begin{array}{rrrr}\text { flexilis. Limber Pine. } & \text { each } & \text { per } 10 & \text { per } 100 \\ 3 & \mathrm{ft} . & \\ 4 & \mathrm{ft} . & & \\ 5 & \mathrm{ft} . & & \\ 6 & \mathrm{ft} . & & \end{array}$

montana. Swiss Mountain Pine.

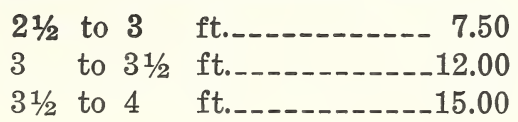

montana mughus. Dwarf Mountain Pine.

18 to 24 in. spread_-_ $5.00 \quad 45.00$

2 to $2 \frac{1}{2}$ ft. spread__-_ $6.50 \quad 55.00$

$21 / 2$ to 3 ft. spread_-_- $7.50 \quad 65.00$

3 to $31 / 2$ ft. spread_._- 12.00

$31 / 2$ to 4 ft. spread__-_ 15.00

nigra. Austrian Pine.

3 ft._--_-_-_-_-_-_-_ $6.50 \quad 55.00$

4 ft._-_._- 7.50 '70.00

5 ft._._. 10.00

5 ft. specimens_-_-_-_-_- 12.50

$6 \mathrm{ft.}$ specimens___-_._-_ 15.00

7 ft. specimens__-_._-_-_ 18.50

8 ft. specimens__________-_22.50

9 ft. specimens___-_-_-_-_25.00

$10 \mathrm{ft}$. specimens_-_._-_._-_30.00

$11 \mathrm{ft.}$ specimens_-_-_-_-_-_37.50

$12 \mathrm{ft}$. specimens_-_-_-_-_-_ 45.00

ponderosa. Western Yellow Pine.

5 ft._._._._. 10.00

6 ft._._._._._._._. 12.50

7 ft._-_-_-_- 15.00

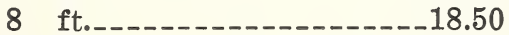

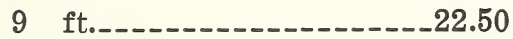

$10 \mathrm{ft.} . \ldots \ldots$

resinosa. Red Pine.

6 ft._-_._-_._._. 12.50

7 ft._._.

8 ft._._._._._._._._._. 18.50

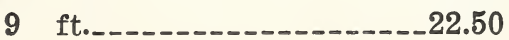




\section{Pinus}

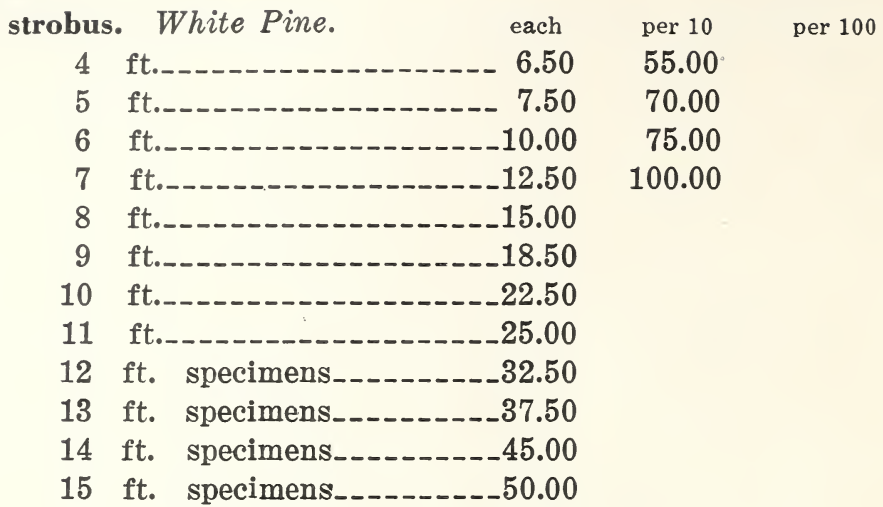

sylvestris. Scotch Pine.

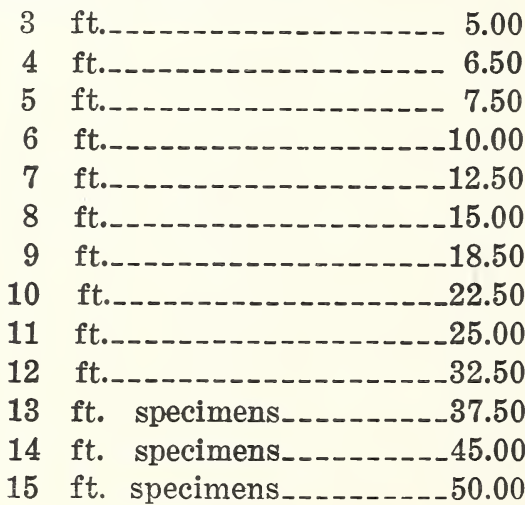

thumbergi. Japanese Black Pine.

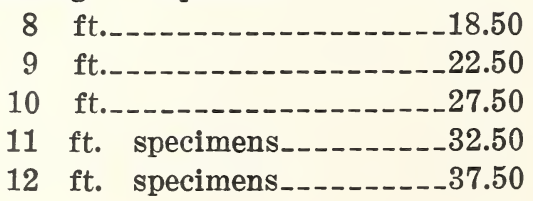

Pseudotsuga douglasi. Douglas Fir.

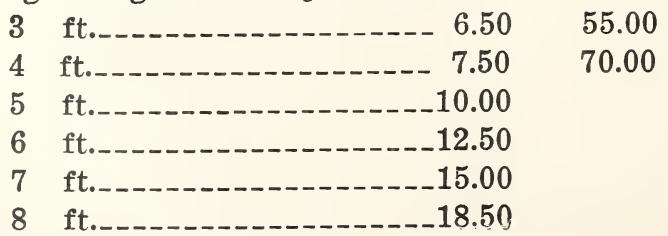


each per 10 per 100

Retinospora filifera. Thread-branched Japanese Cypress.

\begin{tabular}{|c|c|}
\hline 2 & $-\ldots 6.00$ \\
\hline 3 & --n-------- \\
\hline 4 & ft. specimens_____-_-_12.50 \\
\hline 5 & ft. specimens____-_-_15.00 \\
\hline 6 & ft. specimens_________-_18.50 \\
\hline
\end{tabular}

filifera aurea.

Golden Thread-branched Japanese Cypress.

18 in. spread._-_-_-_-_-_ $6.00 \quad 50.00$

24 in. spread_______-_ $6.50 \quad 55.00$

30 in. spread__._._._._.- 7.50

36 in. spread specimens_-_ 12.50

filifera aurea nova.

Variegated Thread-branched Japanese Cypress.

18 to 24 in. spread__._-_-_ $6.00 \quad 50.00$

24 to 30 in. spread__-_-_-_ $6.50 \quad 55.00$

30 to 36 in. spread._-_-_ 10.00

obtusa compacta. Compact Hinoki Cypress.

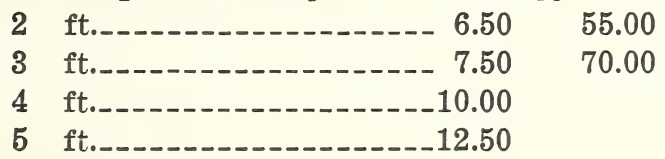

obtusa crippsi. Yellow Hinoki Cypress.

3 ft._._._._._. 10.00

4 ft._-_-_-_.

obtusa gracilis. Slender Hinoki Cypress.

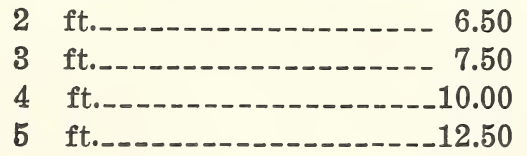

obtusa nana. Dwarf Hinoki Cypress.

12 in.-_-_-_-_-_-_-_ $5.00 \quad 45.00$

15 in...-..- $6.50 \quad 50.00$

18 in.-_- 65.00

24 in..-_.

pisifera. Sawara Cypress.

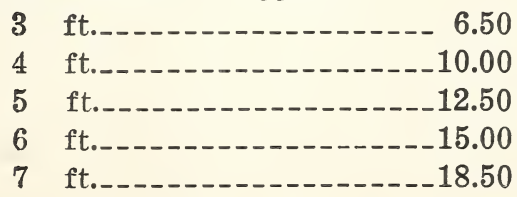


Retinospora pisifera aurea.

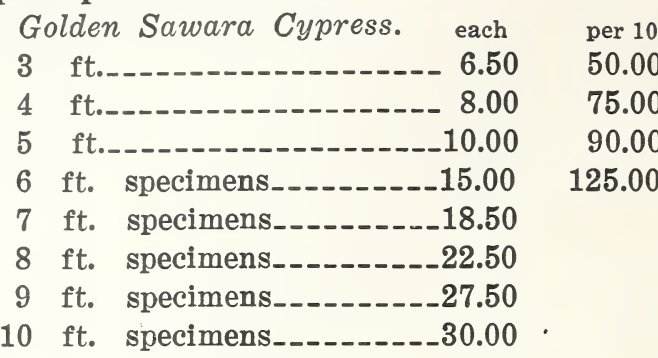

plumosa. Plume Cypress.

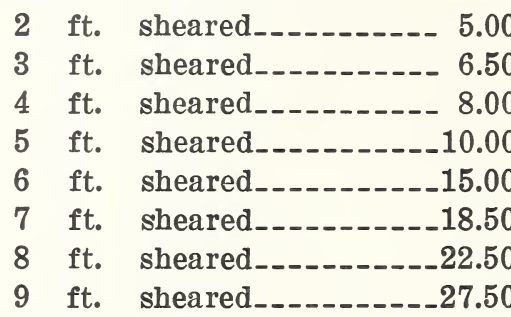

$3 \mathrm{ft}$. high $\times 4 \mathrm{ft}$. spd. extra spec. 12.50

$4 \mathrm{ft}$. high x $5 \mathrm{ft}$. spd. extra spec. 18.50

$5 \mathrm{ft}$. high x $6 \mathrm{ft}$. spd. extra spec. 25.00

plumosa aurea. Goldenplume Cypress.

2 ft. sheared__._-____-_ $4.75 \quad 40.00$

3 ft. sheared_-_-_-_-_-_ $6.00 \quad 52.50$

4 ft. sheared__._-_._- $7.50 \quad 70.00$

$5 \mathrm{ft}$. sheared.-_-_-_.- $10.00 \quad 80.00$

6 ft. sheared._._._._._-_12.50

$7 \mathrm{ft}$. sheared._-_._-_._. 15.00

8 ft. sheared._-_._-_._._18.50

9 ft. sheared_-_-_-_-_-_25.00

$2 \mathrm{ft}$. high $\times 3$ ft. spd. extra spec. 10.00

$3 \mathrm{ft}$. high $x 4 \mathrm{ft}$. spd. extra spec. 12.50

$4 \mathrm{ft}$. high $\times 5 \mathrm{ft}$. spd. extra spec. 18.50

$5 \mathrm{ft}$. high $\times 6$ ft. spd. extra spec. 25.00

plumosa argentea. Silvertip Cypress.

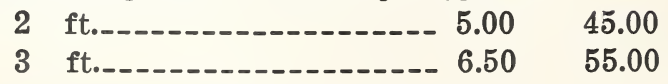

plumosa lutescens. (Globe form.)

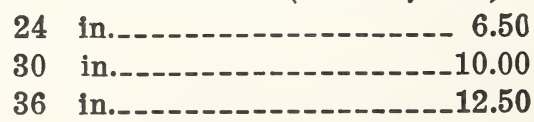


Retinospora.

plumosa sulphurea. Sulphurplume Cypress.

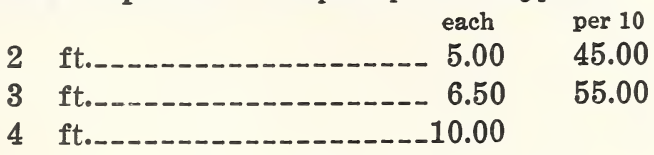

squarrosa. Moss Retinospora.

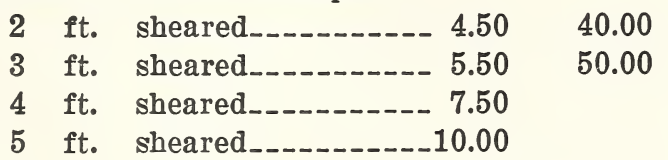

Sciadopitys verticillata. Umbrella Pine.

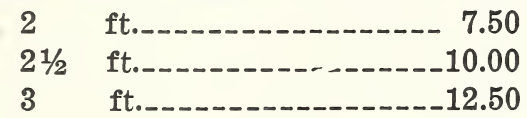

Taxus baccata. English Yew.

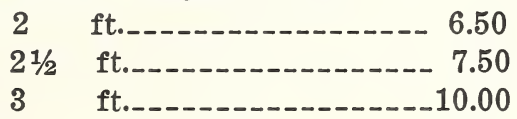

baccata erecta. Broom Yew.

18 in.

baccata fastigiata. Irish Yew.

18 in..-_..- 10.00

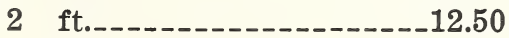

baccata repandens. Spreading English Yew.

18 to 24 in. spread__._-_._- 6.00

baccata washingtoni. Washington Yew.

18 in.._._._._. $5.00 \quad 40.00$

24 in._._._. $6.50 \quad 50.00$

canadensis. Canada Yew.

18 to 24 in. spread_--- 4.50

2 to $2 \frac{1}{2} \mathrm{ft}$. spread._-- 5.00

cuspidata. Japanese Yew.

2 to $2 \frac{1}{2} \mathrm{ft}$. spread._.- 6.50

$2 \frac{1}{2}$ to 3 ft. spread._.- 7.50

3 to $3 \frac{1}{2} \mathrm{ft}$. spread__. 10.00

$31 / 2$ to 4 ft. spread___- 12.50

cuspidata brevifolia. Dwarf Japanese Yew.

18 to 24 in.-_-_-_-_-_- 7.50

24 to 30 in.-_-_- 10.00 
Taxus

cuspidata capitata. Upright Japanese Yew.

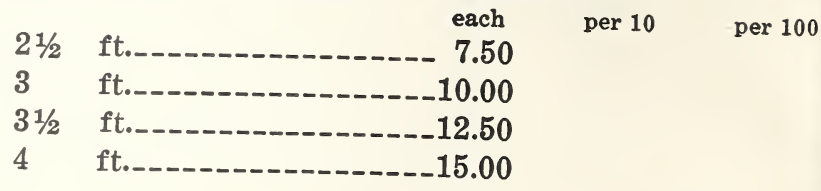

Thuja occidentalis. American Arborvitae.

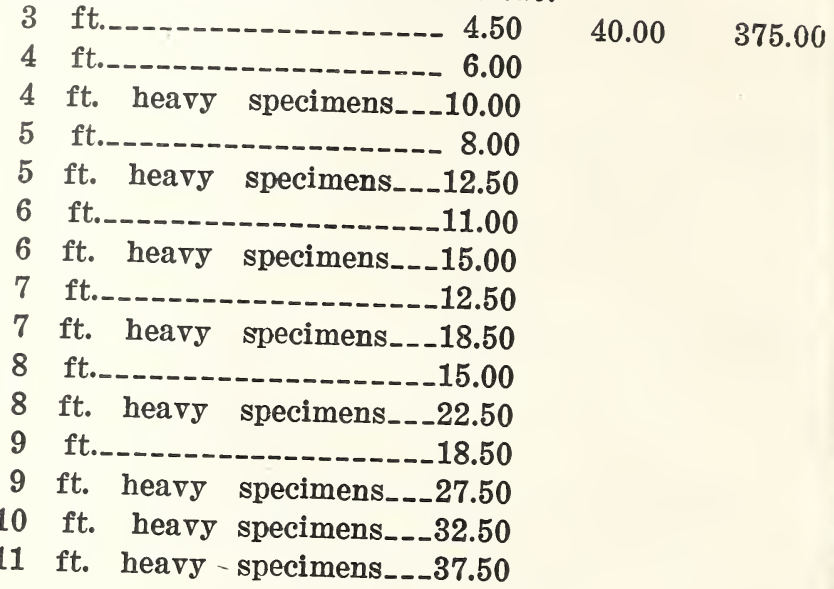

occidentalis aurea douglasi. Douglas Golden Arborvitae

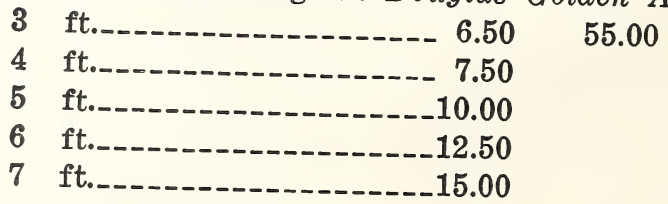

occidentalis columbia. Silver-tipped Arborvitae

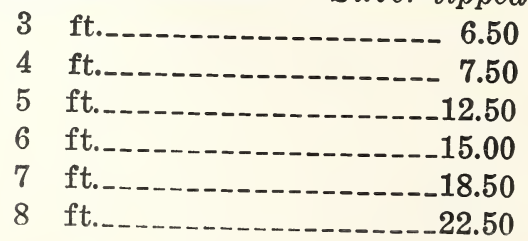

occidentalis compacta. Compact, Arborvitae.

18 in._-_._. $4.00 \quad 37.50$

24 in.----- 


\section{Thuja}

occidentalis compacta. Parsons Arborvitae.

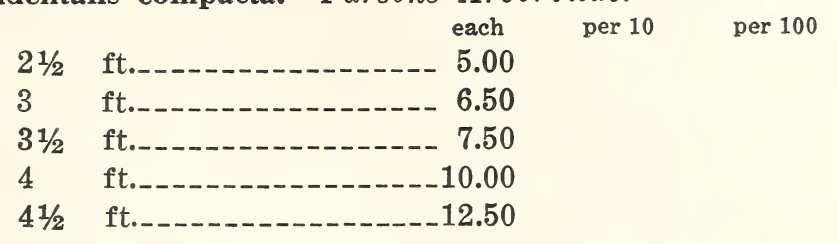

occidentalis elegantissima.

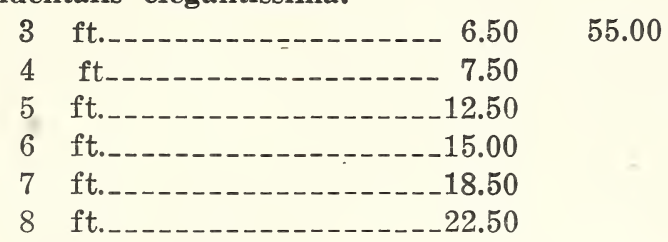

occidentalis ellwangeriana. Tom Thumb Arborvitae.

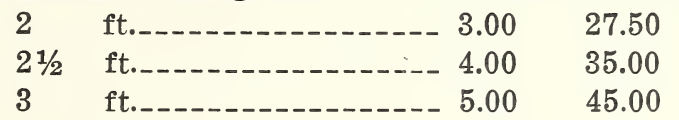

occidentalis ericoides. Heath Arborvitae.

\begin{tabular}{|c|c|}
\hline & 3.00 \\
\hline 2 & ft..-1. 4.00 \\
\hline $1 / 2$ & 5.00 \\
\hline
\end{tabular}

occidentalis globosa. Globe Arborvitae.

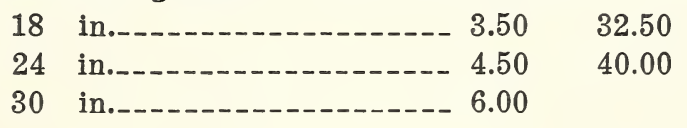

occidentalis hoveyi. Hovey Golden Arborvitae.

\begin{tabular}{|c|c|}
\hline 18 & in._-_- 3.50 \\
\hline 2 & ft._-_-_- 4.00 \\
\hline $21 / 2$ & --5.00 \\
\hline 3 & ----6.50 \\
\hline $31 / 2$ & ft.___. 7.50 \\
\hline 4 & ft.__ 10.00 \\
\hline $41 / 2$ & ft._. \\
\hline 5 & ft. \\
\hline $51 / 2$ & ft.--1, \\
\hline
\end{tabular}


Thuja

occidentalis lutea. Geo. Peabody's Arborvitae.

\begin{tabular}{|c|c|c|}
\hline 2 & $\begin{array}{cc} & \text { each } \\
\text { ft. } & \\
- & 4.50\end{array}$ & $\begin{array}{l}\text { per } 10 \\
40.00\end{array}$ \\
\hline 3 & ft. & 45.00 \\
\hline 4 & 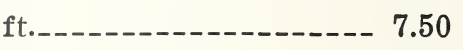 & 70.00 \\
\hline 5 & ft._-_- 10.00 & \\
\hline 6 & ft.-_-_-_-_-_- 12.00 & \\
\hline & ft._-_-_- & \\
\hline & ft._. & \\
\hline
\end{tabular}

occidentalis pumila. Green Globe Arborvitae.

18 in. spread__._-_._-_. 4.00

24 in. spread_-_-_-_-_-_ 5.00

occidentalis pyramidalis. Pyramidal Arborvitae.

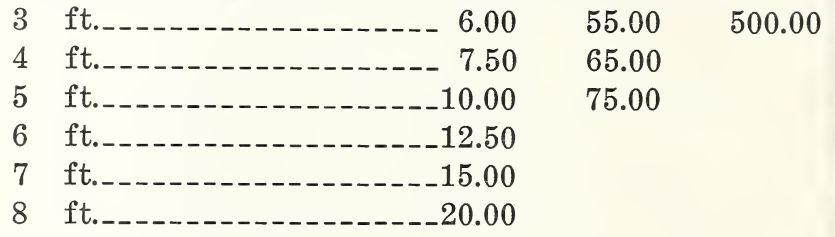

occidentalis douglasi pyramidalis.

Douglas Pyramidal Arborvitae.

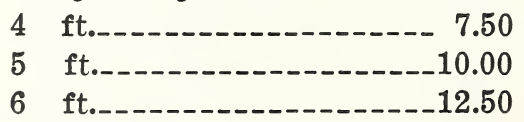

occidentalis reevesi. Reeves Arborvitae.

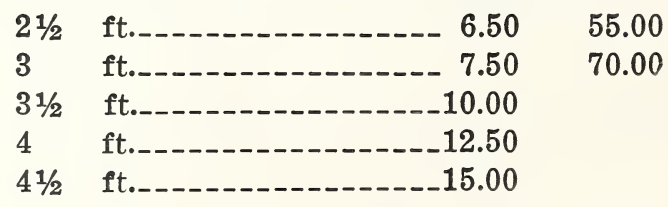

occidentalis reidi. Reid Arborvitae.

\begin{tabular}{|c|c|}
\hline 18 & 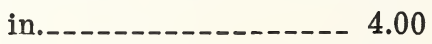 \\
\hline 2 & ft.-_- 5.00 \\
\hline $21 / 2$ & - - - - \\
\hline
\end{tabular}

occidentalis riversi. Rivers Arborvitae.

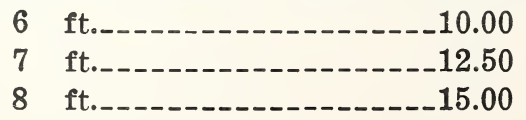


Thuja occidentalis rosenthali. Rosenthal Arborvitae.

$$
4 \text { ft.r.- each per } 10 \quad \begin{aligned}
& 7.50 \\
& 5
\end{aligned}
$$

occidentalis spiralis. Spiral Arborvitae.

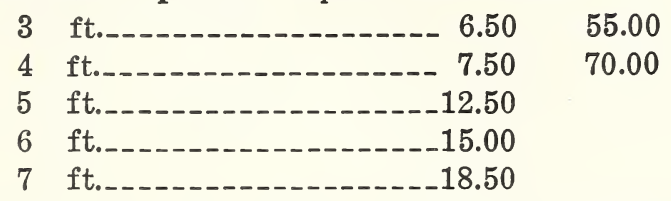

occidentalis umbraculifera. Dwarf Arborvitae.

$\begin{array}{llll}18 & \text { to } 24 & \text { in. spread_--- } 4.00 & 35.00 \\ 24 & \text { to } 30 & \text { in. spread_--- } 5.00 & 47.50 \\ 21 / 2 & \text { to } 3 & \text { ft. spread_--- } 6.50 & \\ 3 & \text { to } 31 / 2 & \mathrm{ft} \text {. spread_-_- } 10.00 & \end{array}$

\begin{tabular}{|c|c|}
\hline 3 & $\mathrm{ft}$. \\
\hline 4 & --10.00 \\
\hline 5 & -12.50 \\
\hline 6 & ft._-1 \\
\hline 7 & ft.-_- \\
\hline & 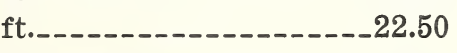 \\
\hline
\end{tabular}

occidentalis vervaeneana. Vervaene Arborvitae.

occidentalis wareana. Ware or Siberian Arborvitae.

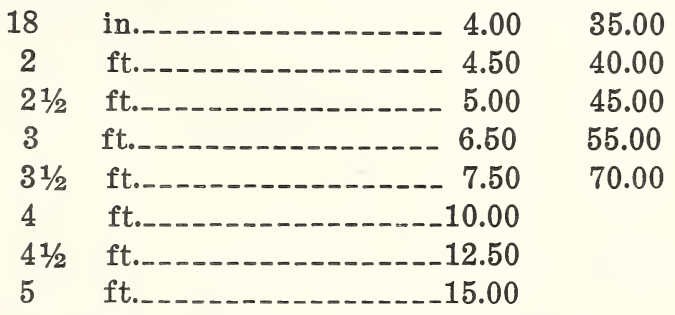

occidentalis wareana lutescens. Golden Ware Arborvitae.

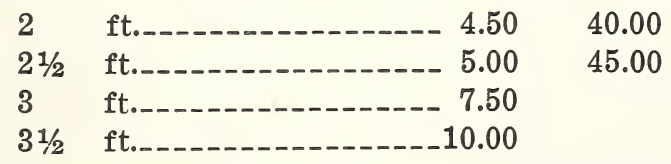

occidentalis woodwardi. Woodward Arborvitae.

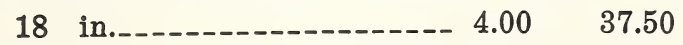

orientalis. Oriental Arborvitae.

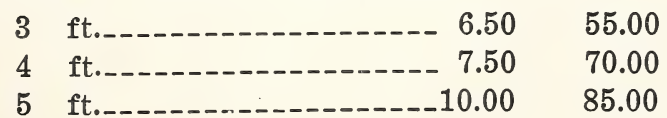


Thuja

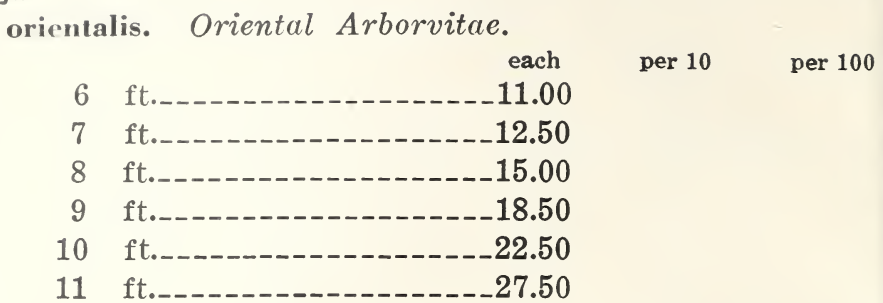

orientalis elegantissima. Rollinson's Golden Arborvitae. 5 ft. 6 ft.

orientalis nana aurea.

Berkmans Golden Arborvitae. 18 in....... 4.50

2 ft....... 5.00

plicata. Giant Arborvitae.

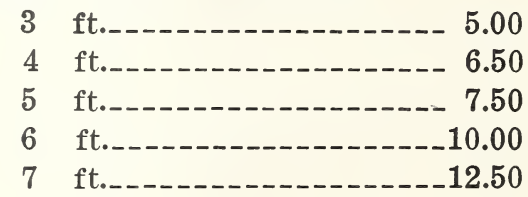

standishi. Standish Arborvitae.<smiles>[2H][14CH2]CCCCCCC</smiles>

$3 \mathrm{ft} . \ldots$.

Tsuga canadensis. Canada Hemlock.

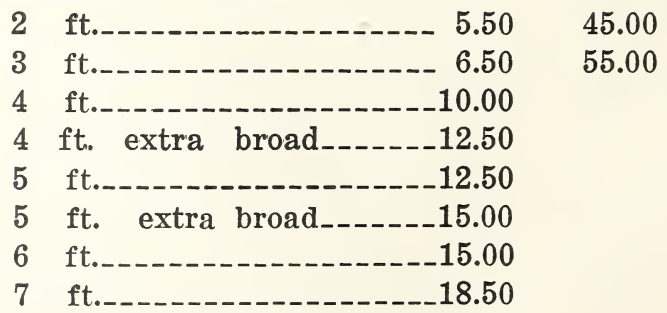

sieboldi. Siebold Hemlock.

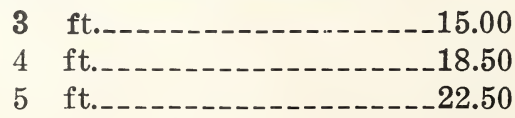




\section{Evergreen Shrubs}

Andromeda floribunda. Mountain Andromeda.

18 to 24 in.-_-_-_B. \& B. $\begin{array}{llrr}\text { each } & \text { per } 10 & \text { per } 100 \\ & 32.50 & 280.00\end{array}$

Azalea amoena. Amoena Azalea.

12 to 15 in._-_._-_B. \& B. 2.75

15 to 18 in._._._._B. \& B. 3.50

hinodegiri. Carmine Azalea.

12 to 15 in._-_._-_B. \& B. 3.25

15 to 18 in.-_-_-_-_B. \& B. 3.75

ledifolia. Snow Azalea.

12 to 15 in._-_B. \& B. 2.00

15 to 18 in..._-_B. \& B. 2.50

yodogawa. Yodogawa Azalea.

12 to 15 in._-_._B. \& B. 2.00

15 to 18 in.-_-_-_B. \& B. 2.50

Calluna vulgaris alba. Heather.

6 to 8 in., 5 in. pots_-__-_ $1.25 \quad 10.00$

vulgaris alporti. Alport Heather.

4 inch pots -

vulgaris carnea. Flesh Heather.

6 to 8 in., 5 inch pots___-_ $1.25 \quad 10.00$

Chamaedaphne calyculata. Leatherleaf.

15 to 18 in._-_._B. \& B. 3.50

Crataegus pyracantha lelandi. Leland Firethorn.

18 to 24 in. bushy_-B. \& B. $3.25 \quad 27.50$

2 to 3 ft. bushy__B. \& B. $3.75 \quad 32.50$

12 to 15 in., 4 in. pots_-_-- $1.25 \quad 10.00$

Daphne cneorum. Garland Flower.

8 to $10 \mathrm{in.}$ spread.-.-.--- $1.50 \quad 14.00$

10 to 12 in. spread__-_-_-_ $2.00 \quad 17.50$

Euonymus nanus. Dwarf Burningbush.

18 to 24 in._-_-_._- $.65 \quad 5.00 \quad 40.00$

radicans. Wintercreeper.

\begin{tabular}{|c|c|c|}
\hline------- & .40 & 3.00 \\
\hline to 15 in. & .50 & 4.00 \\
\hline 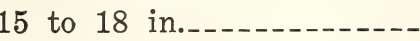 & .60 & 4.50 \\
\hline
\end{tabular}

radicans acutus. Sharpleaf Wintercreeper.

12 to 15 in.-_-_-_-_-_- $.50 \quad 4.00 \quad 35.00$

15 to 18 in.._-_._- .60 $5.00 \quad 45.00$

radicans argenteo-marginatus. Silveredge Wintercreeper.

8 to 12 in._-_-_-_-_.-. $40 \quad 3.00 \quad 25.00$

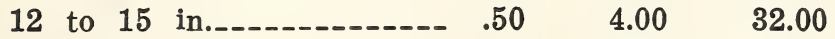

15 to 18 in.-_-..--_-_-- $.60 \quad 4.50 \quad 37.00$ 


\section{Euonymus}

radicans carrieri. Glossy Wintercreeper.

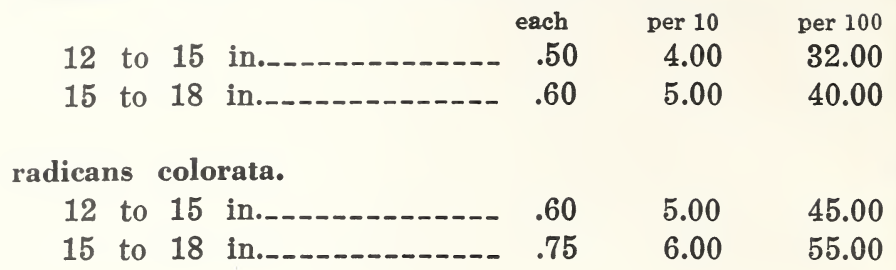

radicans kewensis. Baby Wintercreeper.

8 to 12 in. from pots_._-_.- $.50 \quad 4.00$

radicans vegetus. Bigleaf Wintercreeper.

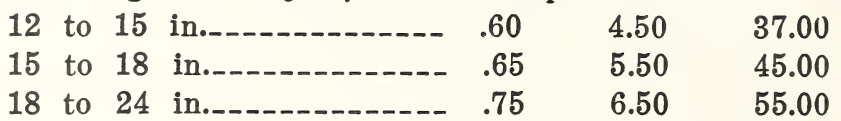

sieboldi.

18 to 24 in._-_._- $1.25 \quad 10.00$

Ilex crenata. Japanese Holly.

15 in._-_-_-_._. \& B. 3.25

18 in._-_._-_._-_B. \& B. 4.50

24 in._-_._._._._. \& B. 6.00

glabra. Inkberry.

18 to 24 in.______ B. B. $3.50 \quad 32.50$

opaca. American Holly.

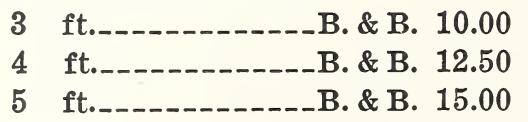

Kalmia latifolia. Mountain Laurel.

2 to 3 ft.______-_B. \& B. $3.75 \quad 32.50 \quad 250.00$

3 to 4 ft.______-_B. \& B. $4.50 \quad 37.50 \quad 325.00$

Leucothoe catesbaei. Drooping Leucothoe.

15 to 18 in._-_-_-_B. \& B. $2.25 \quad 20.00 \quad 160.00$

18 to 24 in.._-___ B. \& B. $2.75 \quad 25.00 \quad 200.00$

Mahonia aquifolium. Oregon Hollygrape.

18 to 24 in.-_-_B. \& B. $2.00 \quad 15.00 \quad 125.00$

24 to 30 in.___B. \& B. $2.50 \quad 20.00 \quad 150.00$ 
Rhododendron carolinianum.

Carolina Rhododendron. each per 10 per 100

2 to 3 ft._-___-_-_B. \& B. $4.50 \quad 37.50 \quad 325.00$

Catawbiense. Catawba Rhododendron.

2 to 3 ft._-_-_-_B. \& B. $4.50 \quad 37.50 \quad 325.00$

3 to 4 ft._-______B. \& B. $5.75 \quad 50.00 \quad 450.00$

maximum. Rosebay Rhododendron.

$\begin{array}{lllll}2 & \text { to } 3 \text { ft._-_-_-_B. \& B. } & 4.00 & 35.00 & 275.00 \\ 3 & \text { to } 4 \text { ft._-_-_-_B. \& B. } & 5.00 & 40.00 & 350.00 \\ 4 \text { to } 5 \text { ft._-_-_-_B. \& B. } & 6.50 & & \end{array}$

\section{Deciduous Trees}

We recommend that all varieties marked with an asterisk be lifted with ball of earth and sewed in burlap. Experience has shown that the loss in these plants, which is otherwise high, is reduced to a minimum if handled in this way. This will involve an extra charge per plant, as follows:

$2-3^{\prime}-30 c ; 3-4^{\prime}-45 c ; 4-5^{\prime}-60 c ; 5-6^{\prime}-75 c ; 6-8^{\prime}-95 c ; 8-10^{\prime}$ -\$1.25. Larger sizes in proportion. In all instances where the varieties are marked "B. \& B." these charges are included in the printed price.

Acer campestre. Hedge Maple.

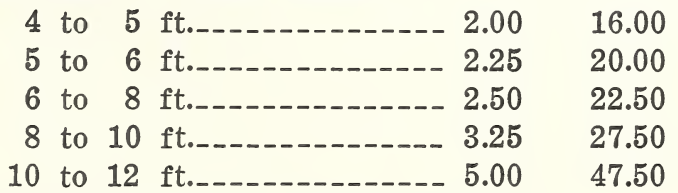

colchicum rubrum. Coliseum Maple.

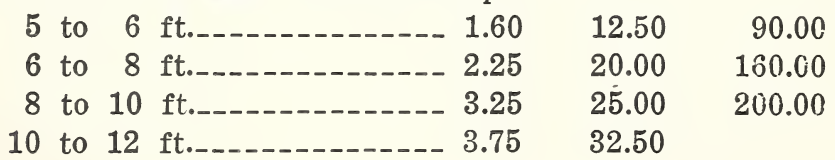

dasycarpum. Silver Maple.

\begin{tabular}{|c|c|c|c|c|}
\hline 8 & to 10 & ft._-_- 2.00 & 16.00 & 125.00 \\
\hline $11 / 4$ & $11 / 2$ & -----2.25 & 20.00 & 150.00 \\
\hline $1 / 2$ & $13 / 4$ & 2.50 & 22.50 & 175.00 \\
\hline $3 / 4$ & to & in._-_. 3.25 & 27.50 & 250.00 \\
\hline & $21 / 2$ & in...... 4.00 & 35.00 & 325.00 \\
\hline $21 / 2$ & to & in.--n- 6.50 & 50.00 & 450.00 \\
\hline & $31 / 2$ & in.-_- 7.50 & 65.00 & \\
\hline $1 / 2$ & 4 & in. 10.00 & 75.00 & \\
\hline
\end{tabular}


Acer

dasycarpum pyramidale. Pyramidal Silver Maple.

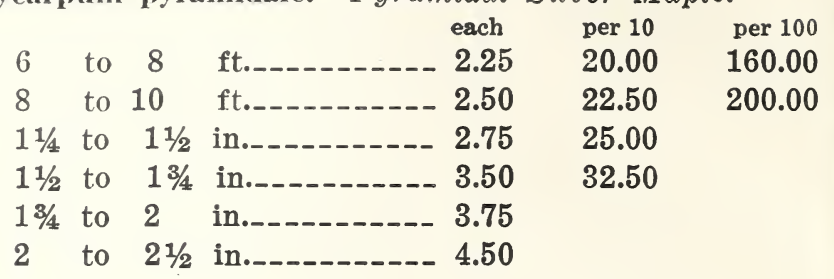

dasycarpum wieri. Wier Maple.

\begin{tabular}{|c|c|c|c|}
\hline & to & 10 & ft._-_-_-_-_- 2.25 \\
\hline $11 / 4$ & to & $11 / 2$ & in.. \\
\hline $11 / 2$ & to & $13 / 4$ & -- 3.50 \\
\hline $13 / 4$ & to & 2 & in.--_-n 4.50 \\
\hline & to & $21 / 2$ & in._-_- 5.75 \\
\hline & & 3 & in. \\
\hline
\end{tabular}

ginnala. Amur Maple.

\begin{tabular}{|c|c|c|c|}
\hline 3 to & ft._-_- 1.25 & 11.00 & 90.00 \\
\hline 4 to & 1.75 & 16.00 & 125.00 \\
\hline 5 to & ft._- & 20.00 & 160.00 \\
\hline 6 to & ft._-_- 2.50 & 22.50 & 200.00 \\
\hline 8 to 10 & 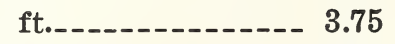 & 30.00 & \\
\hline to 12 & ft._--n-- & 37.50 & \\
\hline
\end{tabular}

japonicum. Fullmoon Maple.

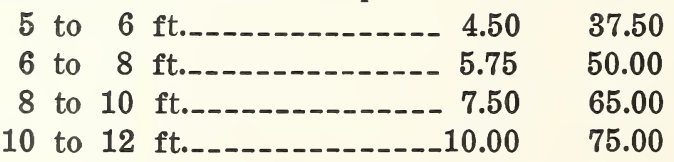

negundo. Box Elder.

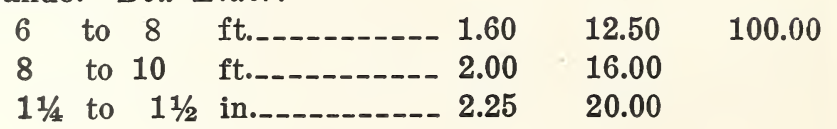

nigrum. Black Maple.

\begin{tabular}{|c|c|c|c|}
\hline 8 & to 10 & ft. & 37.50 \\
\hline $11 / 4$ & to $11 / 2$ & in.-_- 4.75 & 45.00 \\
\hline $11 / 2$ & $13 / 4$ & in.----_------ 5.25 & 50.00 \\
\hline $13 / 4$ & to & in.--------- 6.50 & \\
\hline ? & to $2 \frac{1}{2}$ & in.-_-n 7.50 & \\
\hline
\end{tabular}


Acer

palmatum. Japanese Maple. each per 10 per 100 3 to $4 \mathrm{ft}$. with ball_...- $6.50 \quad 45.00$

4 to $5 \mathrm{ft}$. with ball__._ $\mathbf{7 . 5 0} \quad \mathbf{5 5 . 0 0}$

5 to $6 \mathrm{ft}$. with ball____ $10.00 \quad 75.00$

6 to $8 \mathrm{ft}$. with ball__._. $12.50 \quad 90.00$

8 to $10 \mathrm{ft}$. with ball__._. $15.00 \quad 125.00$

platanoides. Norway Maple.

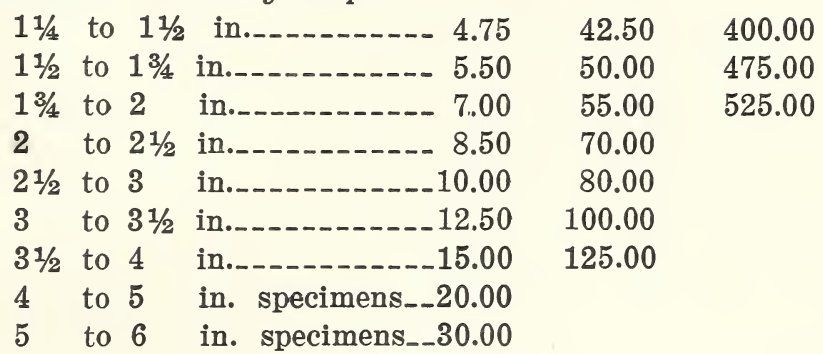

platanoides schwedleri. Schwedler Maple.

\begin{tabular}{|c|c|c|c|}
\hline 8 & to & 10 & $\mathrm{ft}_{0} \ldots \ldots-\ldots-\ldots-15$ \\
\hline $11 / 4$ & to & $11 / 2$ & in._. \\
\hline $11 / 2$ & to & $13 / 4$ & -- 6.50 \\
\hline 2 & to & $21 / 2$ & -10.00 \\
\hline $21 / 2$ & $t$ & 3 & -12.50 \\
\hline 3 & & $31 / 2$ & -20.00 \\
\hline $31 / 2$ & & 4 & in......... \\
\hline
\end{tabular}

pseudoplatanus. Sycamore Maple.

8 to 10 ft........... 3.50

32.50

$1 \frac{1 / 4}{4}$ to $11 / 2$ in.......... 4.00

37.50

$11 / 2$ to $13 / 4$ in.......... $5.25 \quad 50.00$

rubrum. Red Maple.

\begin{tabular}{|c|c|c|c|c|}
\hline 6 & to 8 & ft._______- 2.75 & 25.00 & 225.00 \\
\hline 8 & to 10 & 3.25 & 27.50 & 250.00 \\
\hline $11 / 4$ & $11 / 2$ & in._-_ & 35.00 & 325.00 \\
\hline $11 / 2$ & $13 / 4$ & in_-_-_-_-_ 5.00 & 45.00 & 375.00 \\
\hline $13 / 4$ & to & in... 6.50 & 50.00 & \\
\hline$-7 x$ & $21 / 2$ & in. 7.50 & 65.00 & \\
\hline $21 / 2$ & to & in. & & \\
\hline & to $3 \frac{1}{2}$ & in._-_-_-_-_-_-_12.50 & & \\
\hline
\end{tabular}


Acer

saccharum. Sugar Maple.

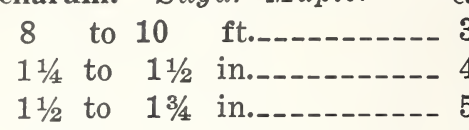

$13 / 4$ to 2 in

2 to $2 \frac{1}{2}$ in

$21 / 2$ to 3

3 to $3 \frac{1}{2}$ in

$31 / 2$ to 4 each

3.25

4.00

5.00

5.50

6.50

7.50

10.00

12.50

spicatum. Mountain Maple.

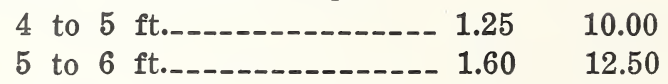

tataricum. Tatarian Maple.

\begin{tabular}{|c|c|}
\hline to & ft._- 2.00 \\
\hline 5 to & ft._-_-_- 2.25 \\
\hline 6 to & ft._-_. \\
\hline to 10 & ft._-_- - - - \\
\hline
\end{tabular}

Aesculus glabra. Ohio Buckeye.

$$
\begin{aligned}
& 1 \frac{1}{2} \text { to } 13 / 4 \text { in.--_-_-_-_- } 4.50 \quad 37.50 \\
& 2 \text { to } 21 / 2 \text { in._._._._. } 5.50 \\
& 21 / 2 \text { to } 3 \text { in.---_-_----- } 7.50
\end{aligned}
$$

hippocastanum. Horsechestnut.

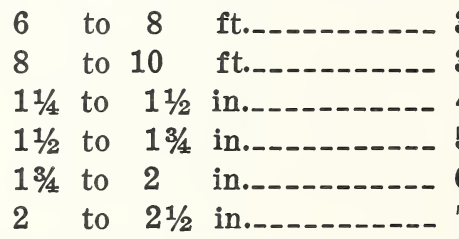

\section{hippocastanum flore pleno.}

Double White Horsechestnut.

$$
\begin{array}{r}
5 \text { to } 6 \mathrm{ft.} \\
6 \text { to } 8 \mathrm{ft.} \\
8 \text { to } 10 \mathrm{ft.}
\end{array}
$$

\begin{tabular}{|c|c|c|c|c|}
\hline 5 & to & ft._. & 32.50 & \\
\hline 6 & to & ft._-_- & 37.50 & 350.00 \\
\hline & to 10 & ft._-_-_- 5.00 & 45.00 & 400.00 \\
\hline $11 / 4$ & $11 / 2$ & in.._- 7.50 & 60.00 & \\
\hline $11 / 2$ & $13 / 4$ & in.-_- 8.50 & 75.00 & \\
\hline $1 \% / 4$ & to 2 & in.... 10.00 & 85.00 & \\
\hline & to $2 \frac{1}{2}$ & in.._- & 100.00 & \\
\hline
\end{tabular}

\section{hippocastanum rubicunda.}

Red Horsechestnut. 


\section{Aesculus}

octandra. Yellow Buckeye.

\begin{tabular}{|c|c|c|c|}
\hline & & $\begin{array}{ll} & \text { each } \\
\text { ft. } & 3225\end{array}$ & $\begin{array}{l}\text { per } 10 \\
30.00\end{array}$ \\
\hline 8 & to 10 & ft._-n-.-- 3.25 & 30.00 \\
\hline $11 / 2$ & to $13 / 4$ & in. & 40.00 \\
\hline $13 / 4$ & to & in. 6.00 & 50.00 \\
\hline ( & $21 / 2$ & in.-- & 65.00 \\
\hline $21 / 2$ & to & in. & 75.00 \\
\hline 3 & to $3 \frac{1 / 2}{2}$ & in.-. & 85.00 \\
\hline
\end{tabular}

turbinata. Japanese Horsechestnut.

\begin{tabular}{|c|c|c|}
\hline 6 & to & ft._-_-_- 3.75 \\
\hline & to 10 & ft.-_-_- 4.50 \\
\hline $11 / 4$ & to $11 / 2$ & in..._- 5.50 \\
\hline $1 / 2$ & $13 / 4$ & in...... 6.50 \\
\hline $3 / 4$ & to & in........ \\
\hline & to $21 / 2$ & in. \\
\hline
\end{tabular}

Ailanthus glandulosa. Tree of Heaven.
5 to $6 \mathrm{ft.}$
6 to
8 to 10
2.25

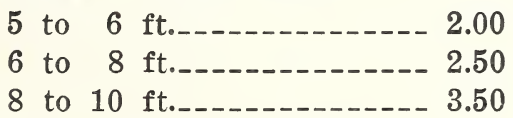

12.50

90.00

20.00

160.00

Alnus cordata. 'Italian Alder.

glutinosa. European Alder.

5 to 6 ft._._._._. 1.25

10.00

90.00

6 to 8

12.50

100.00

8 to 10

2.00

16.00

150.00

$11 / 4$ to $11 / 2$ in........... 2.25

20.00

$1 \frac{1}{2}$ to $1 \frac{3 / 4}{4}$ in

3.25

25.00

$13 / 4$ to 2

32.50

2 to $2 \frac{1}{2}$ in

incana. Speckled Alder.

6 to 8 ft._._-_._-_- $1.60 \quad 12.50$

8 to 10 ft._._-_._-_- $2.00 \quad 16.00$

$11 / 4$ to $11 / 2$ in..._-_._-_. $2.25 \quad 20.00$

$11 / 2$ to $13 / 4$ in._-_._._-_ $3.25 \quad 25.00$

$13 / 4$ to 2 in._._._._-_ $3.75 \quad 32.50$

2 to $2 \frac{1}{2}$ in........... $4.50 \quad 37.50$

japonica. Japanese Alder.

5 to $6 \mathrm{ft.}$

6 to $8 \mathrm{ft.}$ 
Amygdalus davidiana. Chinese Wild Peach

$$
\begin{aligned}
& \text { each per } 10 \\
& 4 \text { to } 5 \text { ft.-_-_-_-_-_--- } 1.00 \quad 7.50 \\
& 5 \text { to } 6 \mathrm{ft} .
\end{aligned}
$$

persica alboplena. Double White Peach.

$$
\begin{aligned}
& 4 \text { to } 5 \text { ft._-_-_-_-_-_-_- } 1.25 \quad 10.00 \\
& 5 \text { to } 6 \mathrm{ft.} \\
& 6 \text { to } 8 \text { ft._-_-_-_-_-_-_-- } 2.00 \quad 15.00
\end{aligned}
$$

persica Clara Meyer. Double Pink Peach.

$$
\begin{aligned}
& 4 \text { to } 5 \text { ft.-_-_-_-_-_-_- } 2.00 \quad 16.00
\end{aligned}
$$

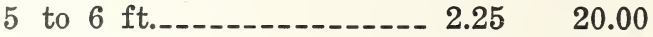

$$
\begin{aligned}
& 6 \text { to } 8 \text { ft._-_-_-_-_-_-_._- } 2.50 \quad 22.50
\end{aligned}
$$

persica rosea plena. Dbl. Pink Peach

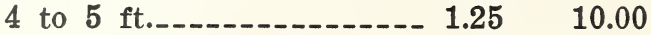

\begin{tabular}{|c|c|c|c|}
\hline & to & ft._-_- & 20.00 \\
\hline & to 10 & --2.75 & 25.00 \\
\hline & $11 / 2$ & 3.25 & 27.50 \\
\hline & $13 / 4$ & in...... & 32.50 \\
\hline & 2 & in....... & 37.5 \\
\hline & $21 / 2$ & -6.50 & 50. \\
\hline
\end{tabular}

$$
\begin{aligned}
& 5 \text { to } 6 \mathrm{ft.} \\
& 6 \text { to } 8 \mathrm{ft.} \text {.--_-_-_-_-_-_- } 2.00 \quad 15.00
\end{aligned}
$$

persica rubroplena. Double Red Peach.

\begin{tabular}{|c|c|c|}
\hline 5 & to & ft._. \\
\hline 6 & to & 2.25 \\
\hline 8 & to 10 & ft.--_-_---- 2.75 \\
\hline $1 / 4$ & $11 / 2$ & ---3.50 \\
\hline
\end{tabular}

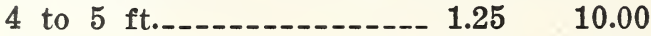

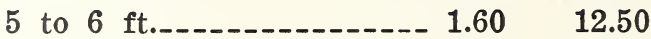

$$
\begin{aligned}
& 6 \text { to } 8 \mathrm{ft} \text {._._._._._._. } 2.00 \quad 15.00
\end{aligned}
$$

Aralia. (See Deciduous Shrubs).

* Betula alba. European White Birch.

*alba laciniata. Cutleaf Weeping Birch.

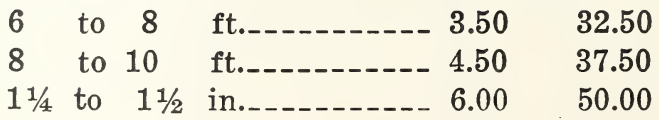

*Ienta. Sweet Birch. 
Betula.

*lutea. Yellow Birch.

each per 10

per 100

5 to 6

$2.00 \quad 16.00$

6 to 8

2.25

20.00

8 to 10

2.75

25.00

$1 \frac{1}{4}$ to $11 / 2$

3.50

32.50

$11 / 2$ to $1 \% / 4$ in

4.50

37.50

*nigra. River Birch.

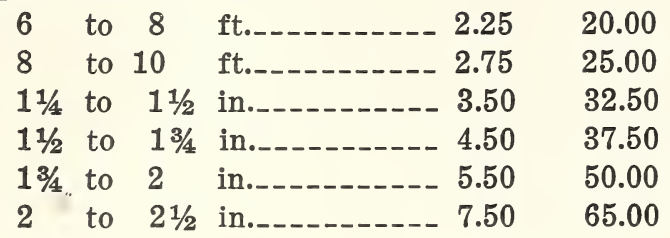

* papyrifera. Canoe Birch.

\begin{tabular}{|c|c|c|c|}
\hline & to & ft._-_-__-_ 2.25 & 20.00 \\
\hline 8 & to 10 & 2.75 & 25.00 \\
\hline $1 / 4$ & $11 / 2$ & 3.25 & 27.50 \\
\hline 1 & $13 / 4$ & in.- & 32.50 \\
\hline $3 / 4$ & to & in...-..-. 4 & 37.5 \\
\hline & $21 / 2$ & in. & .00 \\
\hline 12 & 3 & in._. & 0 \\
\hline
\end{tabular}

*populifolia. Gray Birch.

\begin{tabular}{|c|c|c|}
\hline 8 & 10 & ft._-_-_-_-_-_ 2.75 \\
\hline $11 / 4 t$ & $11 / 2$ & _. 3.25 \\
\hline $11 / 2$ & $13 / 4$ & in.-_-_-_- 3.75 \\
\hline $13 / 4$ & 2 & 4.50 \\
\hline
\end{tabular}

Broussonetia papyrifera. Paper Mulberry.

3 to 4 ft._._-_-_-_-_._-_ $1.25 \quad 10.00$

Carpinus betulus. European Hornbeam.
4 to $5 \mathrm{ft}$
2.25
20.00
5 to
2.75
6 to $8 \mathrm{ft}$ 3.75
25.00
8 to $10 \mathrm{ft}$.
5.00
32.50
10 to $12 \mathrm{ft}$.
45.00
65.00

caroliniana. American Hornbeam.
4 to $5 \mathrm{ft}$.
$2.25 \quad 20.00$
5 to $6 \mathrm{ft}$
2.75
25.00
6 to $8 \mathrm{ft}$.
3.75
32.50
8 to $10 \mathrm{ft}$. $5.00 \quad 45.00$ 
Castanea dentata. American Chestnut.

\begin{tabular}{|c|c|c|}
\hline & & each \\
\hline 5 & to 6 & ft.-_-_- \\
\hline 6 & to 8 & ft._-n_to- 1.60 \\
\hline 8 & to 10 & ft._-_-_-_- 2.00 \\
\hline $11 / 4$ & to $1 \frac{1}{2}$ & in.----- \\
\hline $11 / 2$ & to $13 / 4$ & in.--_-_-.- \\
\hline
\end{tabular}

sativa. Spanish Chestnut.

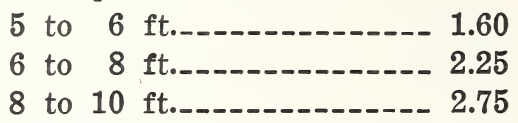

Catalpa bignonioides nana syn. bungei.

Umbrella Catalpa.

2 yr. heads,
5 to
$6 \mathrm{ft}$. 2.75
25.00
6 to
$8 \mathrm{ft}$

kaempferi. Japanese Catalpa.

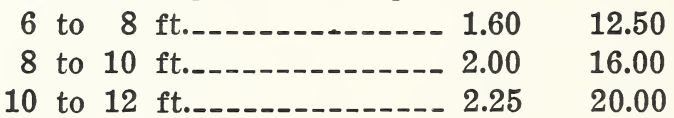

speciosa. Western Catalpa.

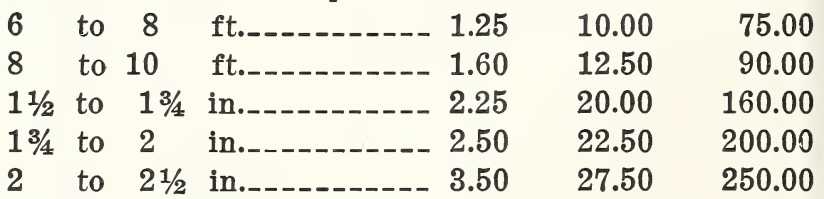

Cedrela sinensis. Chinese Cedrela.

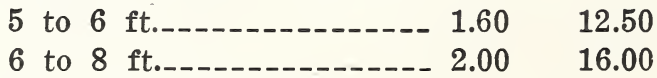

Celtis occidentalis. Hackberry.

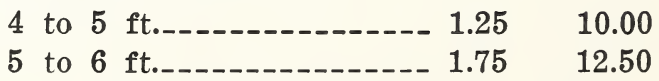

sinensis. Chinese Hackberry.
5 to
$6 \mathrm{ft}$
1.60
6 to $8 \mathrm{ft}$.
2.00
16.00

*Cercidiphyllum japonicum. Katsura Tree.
4 to $5 \mathrm{ft}$
2.00
16.00
5 to $6 \mathrm{ft}$
2.50
20.00
6 to $8 \mathrm{ft}$
3.25
25.00
8 to $10 \mathrm{ft}$.
3.75
32.50
8 to $10 \mathrm{ft}$. trans. spec.__- 12.50
10 to $12 \mathrm{ft}$. trans. spec._._- 15.00
12 to $14 \mathrm{ft}$. trans. spec.-_-_20.00 
Cercis canadensis. American Redbud.

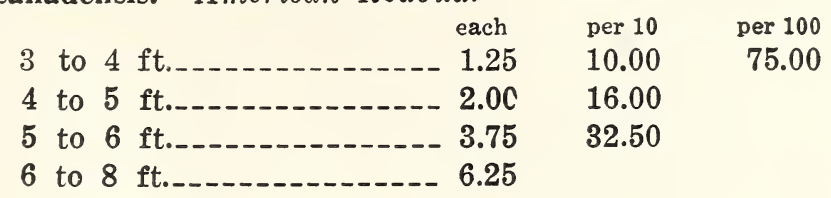

chinensis. Chinese Redbud.

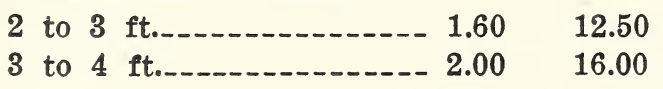

Cladrastis lutea. Yellow Wood.

4 to 5 ft._-_-_-_-_-_-_-_ $2.25 \quad 20.00$

* Cornus florida. White Flowering Dogwood.
3 to 4 ft...-_-_-_-_-_- $1.60 \quad 12.50$
4 to 5 ft._._-_-_-_-_- $2.25 \quad 20.00$
5 to 6 ft._-_-_-_-_-_-_- $2.50 \quad 22.50$
6 to 8 ft..._-_._-_._- $3.75 \quad 32.50$

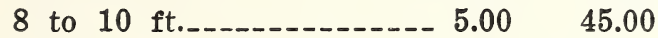
5 to $12 \mathrm{ft}$, heavy specimens, B. \& B. at $\$ 1.50$ per foot.

*florida rubra. Red Flowering Dogwood.

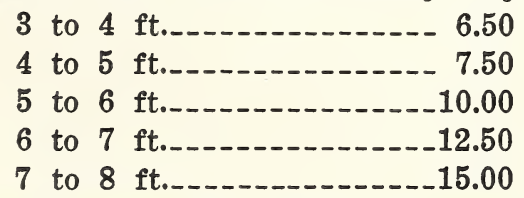

* Crataegus arnoldiana. Arnold Hawthorn.

3 to $4 \mathrm{ft.}$ to $5 \mathrm{ft.}$

*carrierei. Carriere Hawthorn.

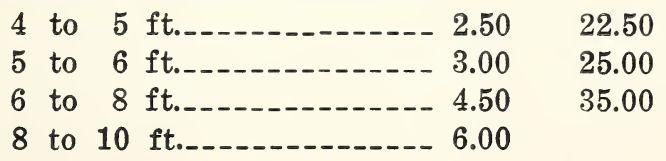

*coccinea. Scarlet-fruited Hawthorn.

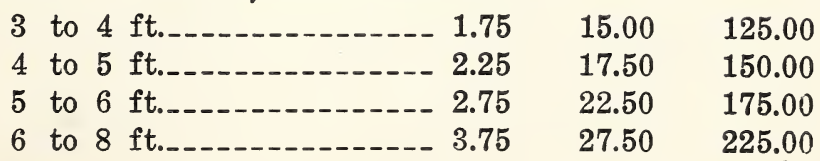


* Crataegus.

* cordata. Washington Hawthorn.

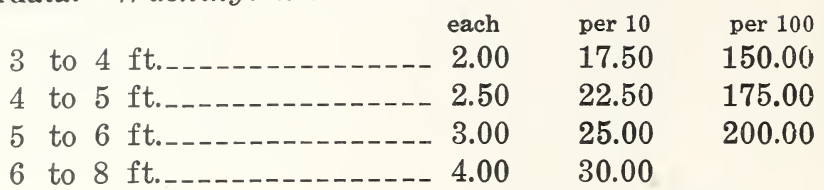

*crusgalli. Cockspur Thorn.

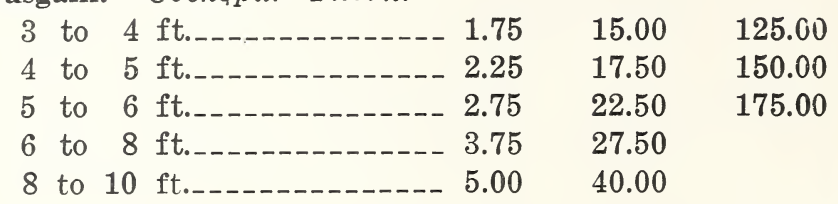

*mollis. Downy Hawthorn.

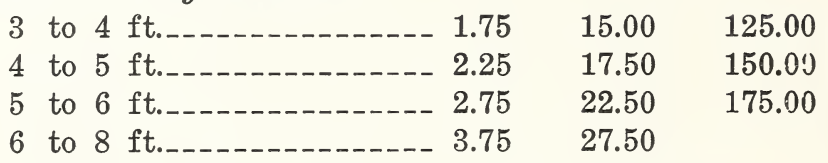

*nitida. Glossy Hawthorn.

3 to 4 ft._._._._._._- 2.00

4 to $5 \mathrm{ft.}$.........-_- 2.50

5 to $6 \mathrm{ft.}$

*oxyacantha. English Hawthorn.

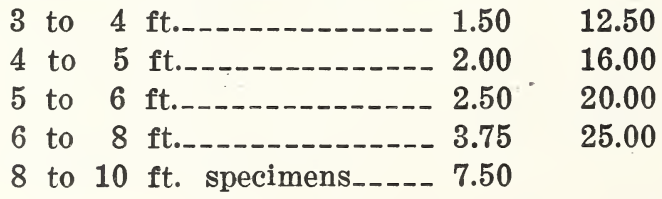

*oxyacantha flora plena. Dbl. White Thorn. 3 to 4 ft._-_-_-_-_-_-_- $2.50 \quad 20.00$

4 to 5 ft.-_-_-_-_-_-_--- $3.25 \quad 25.00$

5 to 6 ft.-_-_-_-_-_-_-- $3.75 \quad 32.50$

6 to 8 ft._._._._._._._. $6.50 \quad 45.00$

8 to $10 \mathrm{ft.}$._-_-_-_-_-_- $7.50 \quad 65.00$

8 to $10 \mathrm{ft}$. specimens_-_-_ 10.00

*oxyacantha pauli. Paul's Scarlet Thorn.

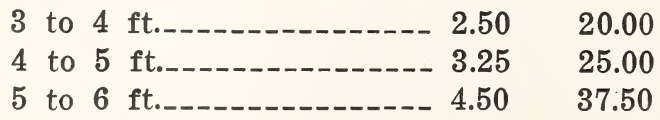


* Crataegus.

*oxyacantha punicea. Sgl. Red Thorn.

$\begin{array}{lrr}4 \text { to } 5 \mathrm{ft.} & \text { each } & \text { per } 10 \\ 5 \text { to } 6 \mathrm{ft.} & \end{array}$

*persistens.

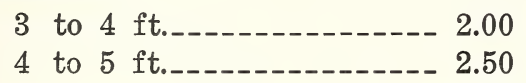

*punctata. Dotted Hawthorn.

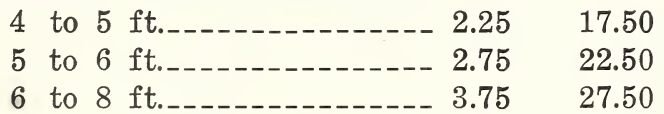

Diospyros virginiana. Common Persimmon.

4 to 5 ft._-_-_-_-_-_-_-_ 1.25

5 to 6 ft.--_-_-_-_----- 1.60

6 to $8 \mathrm{ft}$.

Dirca palustris. Leatherwood.

18 to 24 in._._._._._._._. $1.25 \quad 10.00$

* Fagus americana. American Beech.

\begin{tabular}{|c|c|}
\hline 2 to $3 \mathrm{ft}$. & 16.00 \\
\hline 3 to $4 \mathrm{ft}$. & 20.00 \\
\hline to $5 \mathrm{ft}$. & 25.00 \\
\hline to $6 \mathrm{ft}$. & 32.5 \\
\hline to $8 \mathrm{ft.}$ & 45.0 \\
\hline
\end{tabular}

*sylvatica. European Beech.

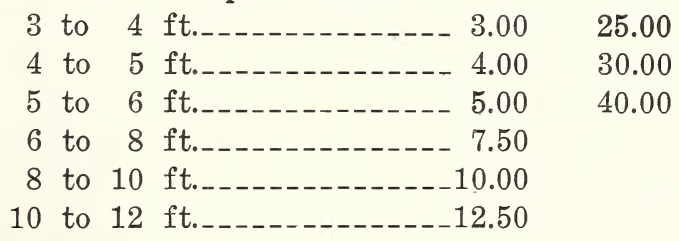

*sylvatica heterophylla. Fernleaf Beech.

4 to 5 ft._._._._._- 7.50

5 to $6 \mathrm{ft.}$

*sylvatica pendula. Weeping Beech.
4 to 5 ft._._-_-_-_-_-_ 7.50
5 to 6 ft.-_-_-_-_-_- 10.00
6 to $8 \mathrm{ft}$._-_-_-_-_-_-_-_-_ 12.50 
*Fagus

*sylvatica purpurea. Purple Beech.

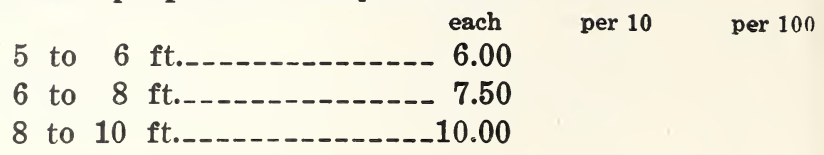

*sylvatica purpurea riversi. River's Beech.

5 to 6 ft._._._-_...- 7.50

6 to 8 ft.-_-_-_-_-_-_- 10.00

8 to $10 \mathrm{ft}$.-.-.-.- 12.50

10 to $12 \mathrm{ft.}$

*sylvatica tricolor. Tricolor Beech.

4 to $5 \mathrm{ft}$.

5 to $6 \mathrm{ft}$._-_-_-_-_._- 7.50

6 to $8 \mathrm{ft}$.

Fraxinus americana. White Ash.

\begin{tabular}{|c|c|c|c|c|}
\hline & to 10 & ft. & 15.00 & 125.00 \\
\hline $1 / 4$ & $11 / 2$ & in. & 17.50 & 150.00 \\
\hline $1 / 2$ & $13 / 4$ & in._- & 25. & 200.0 \\
\hline 3 & to & 3.50 & 32.50 & 300.00 \\
\hline & $21 / 2$ & - - - - - & 45.00 & 400.00 \\
\hline & 3 & in. & 50.00 & \\
\hline
\end{tabular}

excelsior. European Ash.

\begin{tabular}{|c|c|c|c|c|}
\hline $\mathrm{t}$ & to 10 & ft._. & 11.00 & 90.00 \\
\hline $1 / 4$ t & to $11 / 2$ & in. & 16.00 & 125.00 \\
\hline $1 / 2$ t & $13 / 4$ & in.-_- & 20.00 & 160.00 \\
\hline $3 / 4$ & 2 & in.._. & 22.50 & 200.00 \\
\hline tc & $21 / 2$ & in._- 3.50 & 32.50 & \\
\hline $1 / 2$ & 3 & in........ & 37.50 & \\
\hline & $31 / 2$ & in._- & & \\
\hline
\end{tabular}

lanceolata. Green Ash.

\begin{tabular}{|c|c|c|c|c|}
\hline 8 & 10 & ft._-_. & 11.00 & 90.00 \\
\hline $11 / 4$ to & $11 / 2$ & ---2.00 & 16.00 & 125.00 \\
\hline $1 \frac{1}{2}$ tc & $13 / 4$ & in. & 20.00 & 160.00 \\
\hline $13 / 4$ to & 2 & in....... 2.50 & 22.50 & 200.00 \\
\hline 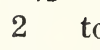 & $21 / 2$ & in. & 32.50 & 250.00 \\
\hline 2 & 3 & in... & 37.50 & \\
\hline & $31 / 2$ & in._. 6.50 & & \\
\hline
\end{tabular}

nigra. Black Ash.

\begin{tabular}{|c|c|c|}
\hline $1 / 4$ to & $11 / 2$ in. & 16.00 \\
\hline to & $13 / 4$ in._- & 20.00 \\
\hline & in........-. 2.50 & 22.50 \\
\hline & $21 / 2$ in.... 3.50 & 32.50 \\
\hline
\end{tabular}


Fraxinus.

\begin{tabular}{|c|c|c|c|c|c|}
\hline ennsylv & vanica. & Red Ash. & each & per 10 & per 100 \\
\hline $11 / 4$ & to $11 / 2$ & 2 in.--_- & 2.00 & 16.00 & \\
\hline $11 / 2$ & to $13 / 4$ & 4 in. & 2.25 & 20.00 & \\
\hline $13 / 4$ & to 2 & in.-_- & 2.50 & 22.50 & \\
\hline 2 & to $21 / 2$ & 2 in. & 3.50 & 32.50 & \\
\hline $21 / 2$ & to 3 & in...-_. & 4.50 & 37.50 & \\
\hline 8 & $31 / 2$ & 2 in. & 6.50 & & \\
\hline
\end{tabular}

quadrangulata. Blue Ash.

\begin{tabular}{|c|c|c|}
\hline $1 \frac{1}{2}$ to & $13 / 4$ & in._- \\
\hline $1 \frac{1}{4}$ to & 2 & -.-- 2.50 \\
\hline 2 & $21 / 2$ & 3.50 \\
\hline $1 / 2$ to & 3 & in.------ 4.50 \\
\hline
\end{tabular}

Ginkgo biloba. Maidenhair-tree.

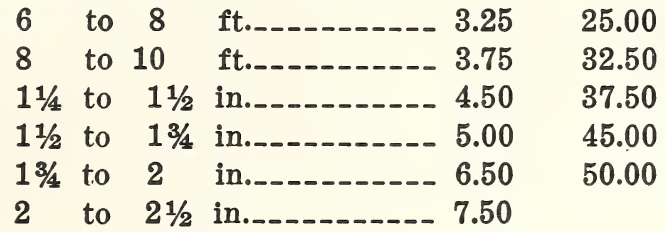

Gleditschia triacanthos. Honey Locust.
4 to $5 \mathrm{ft} . \ldots$.
5 to $6 \mathrm{ft.}$
6 to $8 \mathrm{ft}$
1.25

triacanthos inermis. Thornless Honeylocust.

3 to $4 \mathrm{ft.}$.

4 to $5 \mathrm{ft.}$.

Gymnocladus dioica. Kentucky Coffeetree.

4 to $5 \mathrm{ft.}$

Halesia diptera. Two-wing Silverbell.

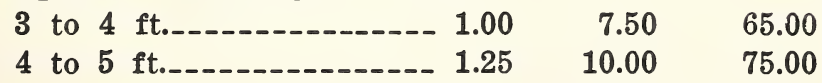

tetraptera. Great Silverbell.

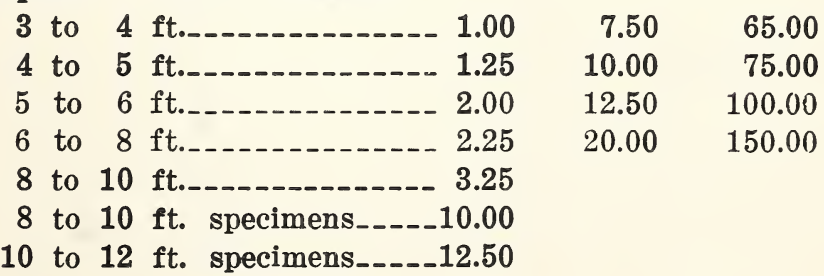


Hicoria ovata. Shagbark Hickory.

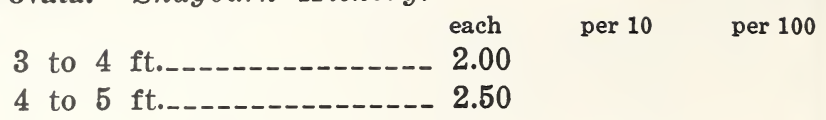

Juglans cinerea. Butternut.

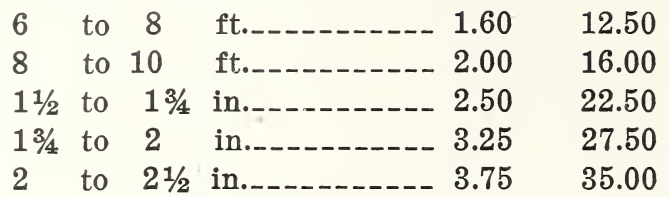

nigra. Black Walnut.

5 to 6 ft._._._._._- $1.25 \quad 10.00$

6 to 8 ft._._._._._._- $1.60 \quad 12.50$

8 to 10 ft._._-_-_-_- $2.00 \quad 16.00$

$1 \frac{1}{2}$ to $13 / 4$ in........-.- $2.50 \quad 22.50$

$13 / 4$ to 2 in._-_._-_._- $3.25 \quad 27.50$

2 to $2 \frac{1}{2}$ in._._._._._.-. 3.75

$2 \frac{1 / 2}{2}$ to 3 in..._....... 4.00

regia. English or Persian Walnut.

2 to $3 \mathrm{ft.}$

3 to 4 ft.-_-_-_-_-_-_-_- 1.75

sieboldiana. Japanese Walnut.

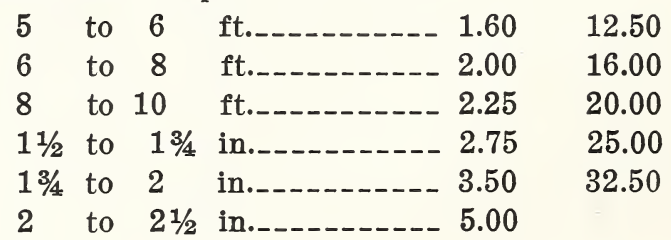

Koelreuteria paniculata. Goldenrain Tree.
4 to $5 \mathrm{ft}$
1.75
15.00
5 to $6 \mathrm{ft}$
17.50
6 to $8 \mathrm{ft}$.
3.25
8 to $10 \mathrm{ft}$._._._._-_._- 5.00

Laburnum alpinum. Scotch Laburnum.

5 to 5 ft._. 6 ft._- 2.00

vulgare. Goldenchain.

3 to 4 ft._._._._._._...... 1.60

4 to 5 ft._-_._._-_._- 2.00

5 to $6 \mathrm{ft}$.

6 to $8 \mathrm{ft}$. heavy_-_-_-_- 7.50

8 to $10 \mathrm{ft}$. heavy__.___._. 10.00 
*Larix europea. European Larch. each

per 10

20.00

25.00

37.50

6 to

3.25

8 to 10

4.50

6.50

10 to 12

*leptolepis. Japanese Larch.

\begin{tabular}{|c|c|}
\hline to & ft._-_-n- 2.50 \\
\hline 5 to & 3.25 \\
\hline 6 to & ft._-n- \\
\hline 8 to 10 & ft._-n-n- 6.50 \\
\hline to 12 & 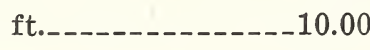 \\
\hline
\end{tabular}

*Liquidambar styraciflua. Sweetgum.

\begin{tabular}{|c|c|c|c|}
\hline 6 & to & 3.00 & 25.00 \\
\hline 8 & to 10 & 3.50 & 30.00 \\
\hline $1 \frac{1}{4}$ & $11 / 2$ & --4.00 & 35.00 \\
\hline $11 / 2$ & $13 / 4$ & in.-_-_- 4.50 & 40.00 \\
\hline $3 / 4$ & to & in._- 5.00 & 45.00 \\
\hline & $21 / 2$ & in.-_...-- 7.50 & 60.00 \\
\hline 21 & D & in.--n- 12.50 & \\
\hline & $31 / 2$ & in..-_-_-_-_ 15.00 & \\
\hline
\end{tabular}

*Liriodendron tulipifera. Tuliptree.

\begin{tabular}{|c|c|c|c|c|}
\hline 5 & to 6 & ft._-_-_-_- 1.50 & 12.50 & \\
\hline 6 & to & ft.__n- & 16.00 & 125.00 \\
\hline 8 & to 10 & ft.---------- 2.75 & 20.00 & 160.00 \\
\hline $11 / 4$ & to $1 \frac{1 / 2}{2}$ & in.--_- 3.00 & 25.00 & 200.00 \\
\hline $1 \frac{1}{2}$ & $13 / 4$ & in.-- & 27.50 & 225.00 \\
\hline $13 / 4$ & to & in...- 3.75 & 30.00 & 275.00 \\
\hline 2 & to $21 / 2$ & in.-_-n- 4.50 & 37.50 & \\
\hline $21 / 2$ & to 3 & in.-_- 5.00 & 45.00 & \\
\hline 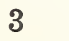 & $31 / 2$ & in.------- & & \\
\hline
\end{tabular}

tulipifera pyramidale. Pyramid Tuliptree.

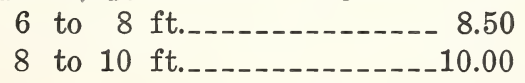

Magnolia acuminata. Cucumber Tree.

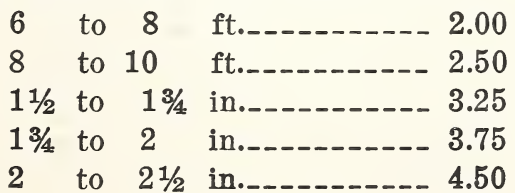


Magnolia.

glauca. Sweetbay.

$$
\text { each }
$$

2 to $3 \mathrm{ft}$. with ball_..... 3.25

per 10

per 100

3 to $4 \mathrm{ft}$. with ball_-_---- 4.50

25.00

225.00

4 to $5 \mathrm{ft}$. with ball_._._.- 6.50

37.50

300.00

5 to $6 \mathrm{ft}$. with ball_-_--- 7.50

50.00

450.00

6 to $8 \mathrm{ft}$. with ball

65.00

8 to $10 \mathrm{ft}$. with ball__-_-_ 12.50

75.00

10 to $12 \mathrm{ft}$. with ball_-_-_-_15.00

90.00

125.00

*hypoleuca. Silver Magnolia.

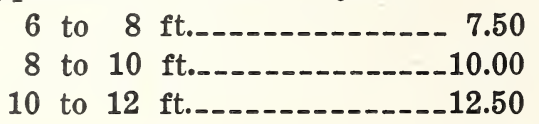

*kobus. Kobus Magnolia.

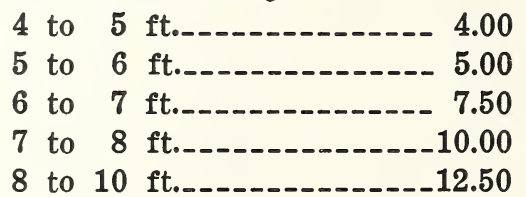

tripetala. Umbrella Magnolia.

5 to $6 \mathrm{ft}$. with ball__._-_ 5.00

6 to $8 \mathrm{ft}$. with ball_._-_- 7.50

8 to $10 \mathrm{ft}$. with ball

10 to $12 \mathrm{ft}$. with ball____-_12.50

Malus arnoldiana. Arnold Crab.

\begin{tabular}{|c|c|}
\hline$-\ldots-1.50$ & 12.50 \\
\hline 4 to $5 \mathrm{ft}$. & 20.00 \\
\hline 5 to $6 \mathrm{ft}$. & 25.00 \\
\hline 6 to $8 \mathrm{ft}$. & 32.50 \\
\hline
\end{tabular}

baccata. Siberian Crab.

\begin{tabular}{|c|c|}
\hline 2.00 & 12.50 \\
\hline 4 to $5 \mathrm{ft}$. & 20.00 \\
\hline 6 ft.-_- 3.25 & 25.00 \\
\hline $8 \mathrm{ft}$. & 32.5 \\
\hline
\end{tabular}

coronaria. Wild Sweet Crab.

\begin{tabular}{|c|c|}
\hline$-\ldots-25$ & 10.00 \\
\hline 4 to $5 \mathrm{ft}$. & 12.50 \\
\hline to $6 \mathrm{ft}$. & 16.00 \\
\hline to $8 \mathrm{ft}$.-1-- & 20.00 \\
\hline
\end{tabular}

Elisa Rathke. Weeping Flg. Apple.

3 to $4 \mathrm{ft}$. spread._._._- 2.00 
Malus.

floribunda. Japanese Flowering Crab.

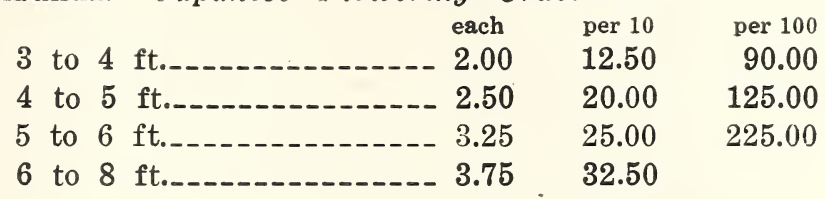

floribunda atrosanguinea. Carmine Crab.

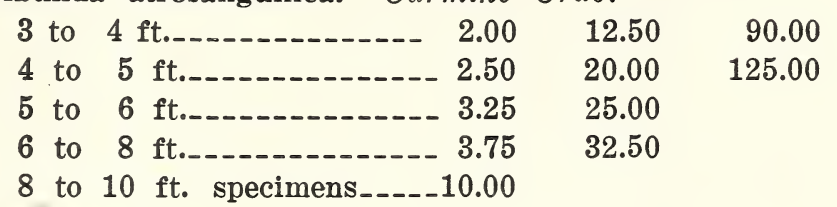

floribunda purpurea. Purple Crab.

3 to 4 ft._.
4 to $5 \mathrm{ft}$.
5 to $6 \mathrm{ft} . \ldots$
6 to $8 \mathrm{ft}$.

halliana parkmani. Parkman Crab.

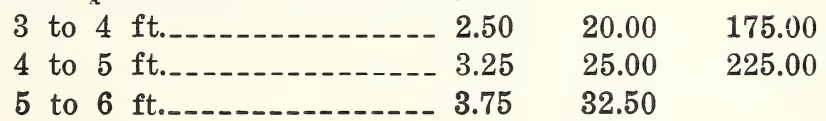

ioensis bechteli. Bechtel Crab.

3 to $4 \mathrm{ft} . \ldots$
4 to $5 \mathrm{ft} . \ldots$
5 to $6 \mathrm{ft} . \ldots \ldots$

kaido. Red Flg. Crab.

3 to $4 \mathrm{ft}$.
4 to $5 \mathrm{ft}$.

micromalus. Midget $\mathrm{Crab}$.

3 to $4 \mathrm{ft.}$

niedzwetzkyana. Redvein Crab.

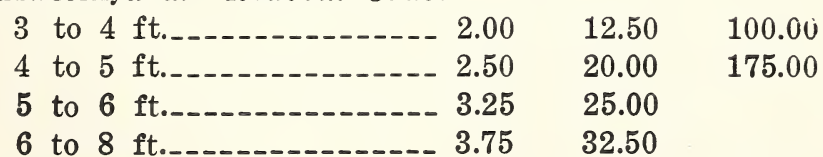

prunifolia rinki. Chinese Apple.

3 to $4 \mathrm{ft}$.

4 to $5 \mathrm{ft}$.

sargenti. Sargent Crab.

3 to 4 ft.
4 to 5 ft. 
Malus.

scheideckeri. Scheidecker Crab.

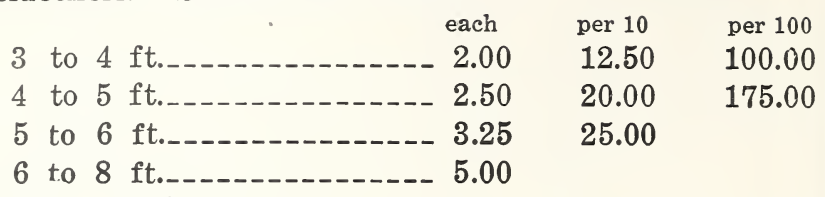

sieboldi. Toringo Crab.

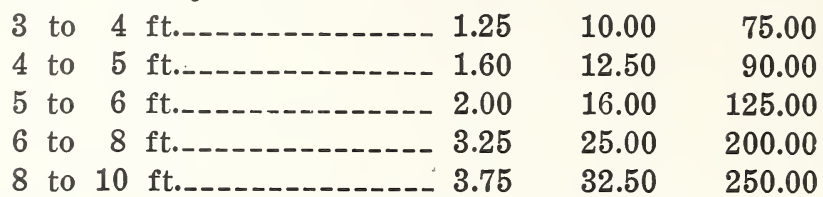

sieboldi calocarpa. Small-fruited Toringo Crab.

3 to $4 \mathrm{ft.}$

4 to 5 ft._._._._._- $1.60 \quad 12.50 \quad 100.00$

5 to 6 ft.-_-_-_-_-_- $2.00 \quad 16.00$

spectabilis. Chinese Flowering Crab.

3 to 4 ft.---_---_-_----- $2.00 \quad 12.50$

4 to 5 ft._-_-_-_-_-_-_-- $2.50 \quad 20.00$

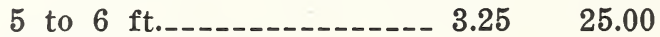

spectabilis alba plena.

Dbl. White Chinese Crab.

\begin{tabular}{|c|c|}
\hline to $4 \mathrm{ft.} .-$ & 12.50 \\
\hline 2.50 & 20.00 \\
\hline ft._- & 25.00 \\
\hline 6 to 8 ft. & 32.50 \\
\hline
\end{tabular}

zumi. Zumi Crab.

3 to 4 ft.-_-_-_-_-_- $2.00 \quad 12.50$

4 to 5 ft.-.--_-_-_-_-- $2.50 \quad 20.00$

5 to 6 ft.-_-_-_-_-_-_- $3.25 \quad 25.00$

6 to 8 ft._._-_-_-_-_-_- $3.75 \quad 32.50$

8 to $10 \mathrm{ft}$.-_-_- 37.50

Morus alba pendula. Weeping Mulberry

$2 \mathrm{yr}$. heads, 5 to $7 \mathrm{ft}$. stems 3.75

alba tartarica. Russian Mulberry.

\begin{tabular}{|c|c|c|}
\hline to & .65 & 4.50 \\
\hline to & ---- & 6.50 \\
\hline to & ft._-n- 1.25 & 10.00 \\
\hline to 10 & ft. & 12.50 \\
\hline
\end{tabular}

Nyssa sylvatica. Tupelo.

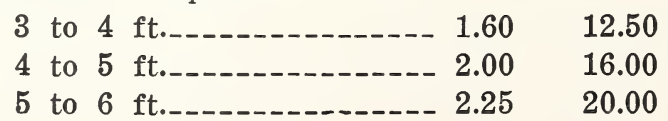


Ostrya virginiana. American Hophornbeam.

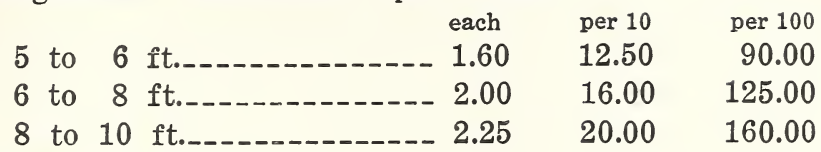

Oxydendrum. (See Shrubs).

Paulownia tomentosa. Royal Paulownia.

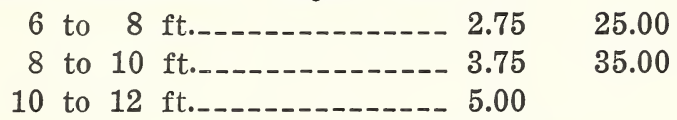

Phellodendron amurense. Amur Corktree.

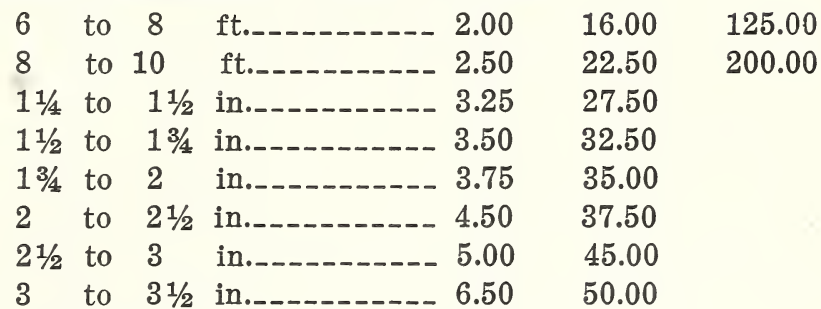

Platanus orientalis. European Planetree.

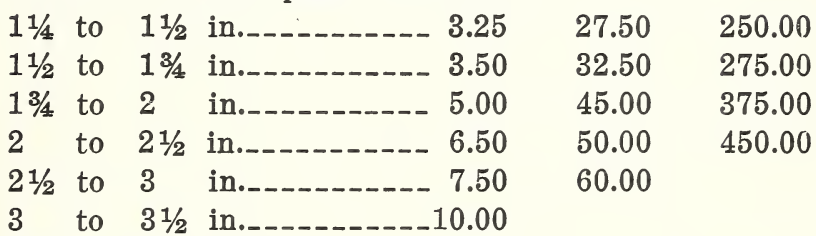

Populus alba. White Poplar.

\begin{tabular}{|c|c|c|c|}
\hline 6 & to 8 & ft._- 1.10 & 10.00 \\
\hline 8 & to 10 & ft.-n-n-n-n 1.25 & 11.00 \\
\hline 10 & to 12 & ft._-n_-n--n 2.00 & 16.00 \\
\hline $11 / 2$ & $13 / 4$ & in.--n-n- 2.25 & 20.00 \\
\hline $13 / 4$ & to & in.-_-n 3.25 & 25.00 \\
\hline 2 & to $21 / 2$ & in.._. 4.00 & 30.00 \\
\hline
\end{tabular}

berolinensis. Volga Poplar.

6 to $8 \mathrm{ft.}$

bolleana. Bolleana Poplar.

\begin{tabular}{|c|c|c|c|c|c|}
\hline 6 & to & 8 & ft._-_-_o 2.00 & 17.50 & 160.00 \\
\hline 8 & to & 10 & $-\ldots---2.25$ & 20.00 & 190.00 \\
\hline $11 / 4$ & to & $11 / 2$ & $\ldots .25$ & 27.50 & 250.00 \\
\hline $11 / 2$ & to & $13 / 4$ & in. & & \\
\hline $13 / 4$ & to & 2 & in..-n--n-- 5.00 & & \\
\hline 8 & & $21 / 2$ & in..... 6.50 & & \\
\hline $21 / 2$ & & 3 & In. & & \\
\hline
\end{tabular}


Populus.

certinensis. Certinensis Poplar

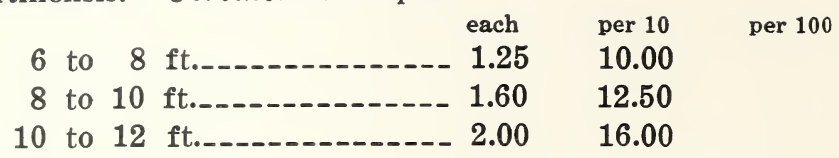

nigra italica. Lombardy Poplar.

6 to 8 ft. low branched $1.00 \quad 7.50$

65.00

8 to 10 ft. low branched 1.25

10.00

75.00

10 to 12 ft. low branched 2.00

16.00

110.00

$1 \frac{1}{2}$ to $1 \frac{3 / 4}{} \mathrm{in}$. low branched 2.25

20.00

$13 / 4$ to 2 in. low branched 3.25

25.00

2 to $2 \frac{1}{2}$ in. low branched 4.50

37.50

$2 \frac{1}{2}$ to 3 in. low branched 6.50

50.00

tremuloides. Quaking Aspen.

6 to 8 ft._._._._._._. $1.25 \quad 10.00$

8 to $10 \mathrm{ft.}$.._-_._-_._-_ $1.50 \quad 1250$

trichocarpa. Black Cottonwood.

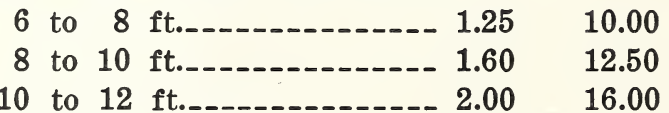

\section{Prunus avium plena.}

Double White Flowering Cherry.

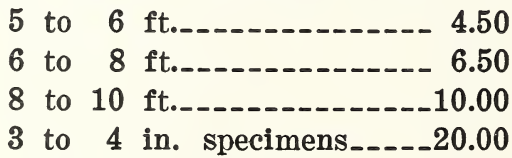

37.50

50.00

3 to 4 in. specimens_-_-_ 20.00

lannesiana. Hitoye Cherry.

\begin{tabular}{|c|c|}
\hline $5 \mathrm{ft} . \ldots$ & 2.00 \\
\hline ft._-_- & 2.50 \\
\hline to $8 \mathrm{ft}$. & 3.75 \\
\hline
\end{tabular}

padus. European Bird Cherry.

\begin{tabular}{|c|c|c|}
\hline to & ft. & 5.00 \\
\hline 5 to & -.--- $\quad .75$ & 6.50 \\
\hline to & ft._-_- & 10.00 \\
\hline to 10 & ft._. & 12.50 \\
\hline
\end{tabular}

persica. (See Amygdalus).

serotina. Wild Black Cherry.

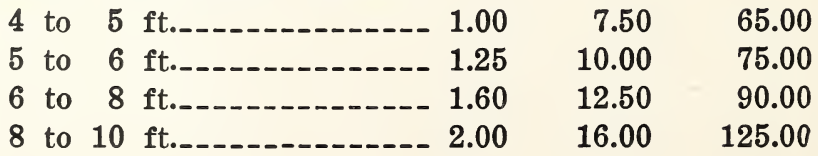




\section{Prunus.}

serrulata. Oriental Cherry.

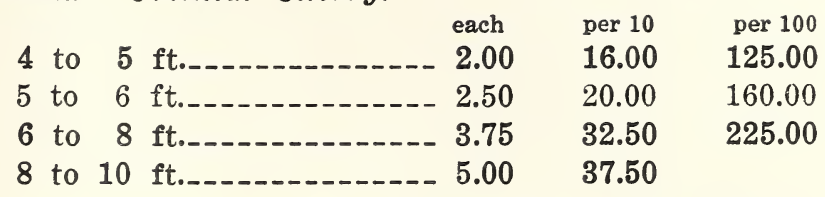

serrulata Higantakura. Dbl. White Flg. Cherry.

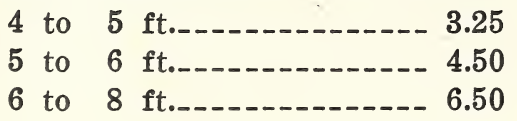

serrulata Hisakura. Dbl. Pink Flg. Cherry.

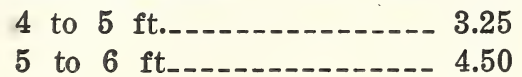

serrulata James H. Veitch.

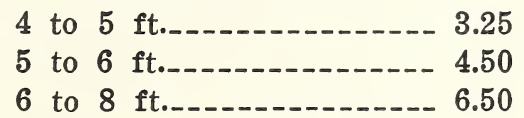

serrulata sachalinensis. Yama Cherry.

\begin{tabular}{|c|c|}
\hline to & ft._- \\
\hline to & 2.50 \\
\hline to & 3.75 \\
\hline to 10 & ft.--_o \\
\hline
\end{tabular}

sieboldi. Siebold Cherry.
6 to $8 \mathrm{ft}$.

8 to $10 \mathrm{ft}$ $-10.00$

subhirtella. Higan Cherry.

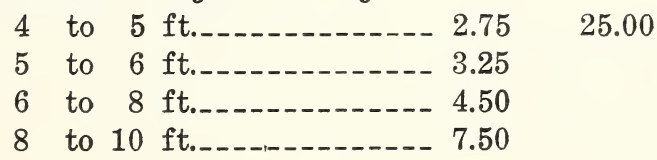

subhirtella autumnale.

\begin{tabular}{|c|c|c|}
\hline Autumn & flowering Higan Cherry. & \\
\hline 4 to & $5 \mathrm{ft} . \ldots$ & 25.00 \\
\hline 5 to & $6 \mathrm{ft.}$. & 37.50 \\
\hline 6 to & $8 \mathrm{ft} . \ldots$ & 50.00 \\
\hline 8 to 10 & 9.00 & \\
\hline
\end{tabular}

subhirtella pendula. Weeping Higan Cherry.

2 yr. heads, 4 to $6 \mathrm{ft}$. stem 6.50

yedoensis. Yoshino Cherry.

5 to $6 \mathrm{ft}$. 
Ptelea trifoliata. Hoptree. each

\begin{tabular}{|c|c|c|c|}
\hline 3 to & Et._-_- .65 & 5.00 & 40.00 \\
\hline to & ft.-_-_- & 6.50 & 50.00 \\
\hline to & ft.--no 1.00 & 7.50 & 65.00 \\
\hline to & ft..-n- 1.60 & 12.50 & 90.00 \\
\hline to 10 & t._._- & 16.00 & 125.0 \\
\hline
\end{tabular}

Quercus alba. White Oak.

\begin{tabular}{|c|c|c|c|}
\hline & to 8 & ft._-_-_-_-_ 3.75 & 32.50 \\
\hline $1 / 4$ & to $1 \frac{1}{2}$ & ----4.50 & 37.50 \\
\hline 1 & to $13 / 4$ & 5 & 5.00 \\
\hline 18 & & 6.50 & 0.00 \\
\hline & to $2 \frac{1}{2}$ & in.-.-n- & 5.00 \\
\hline & & in.. & 75. \\
\hline
\end{tabular}

bicolor. Swamp White Oak.

6 to 8 ft._._-___-_ 3.75

$1 \frac{1}{4}$ to $1 \frac{1}{2}$ in............ 4.50

cerris. European Turkey Oak.

$11 / 4$ to $11 / 2$ in._-_._-_-_ $3.50 \quad 32.50$

$1 \frac{1}{2}$ to $13 / 4$ in.--_-_-_-_-_ $4.00 \quad 37.50$

$13 / 4$ to 2 in._-_._-_._- $4.75 \quad 45.00$

2 to $2 \frac{1}{2}$ in._._._._._- $6.50 \quad 55.00$

$21 / 2$ to 3 in.-_-_-_-_- $7.50 \quad 67.50$

coccinea. Scarlet Oak.

$1 \frac{1 / 4}{4}$ to $1 \frac{1}{2}$ in..-_-_-_-_-_ 4.50

$1 \frac{1}{2}$ to $1 \frac{3 / 4}{4}$ in..-_.-_-_- 5.00

$13 / 4$ to 2 in._._._._- 6.50

2 to $2 \frac{1}{2}$ in........-.-. 7.50

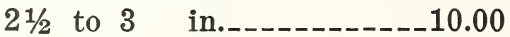

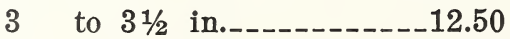

$31 / 2$ to 4 in.._-_._._._. 17.50

ilicifolia. Scrub Oak.

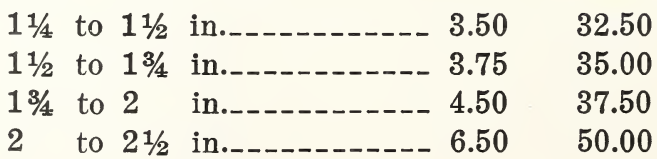

macrocarpa. Mossycup Oak.

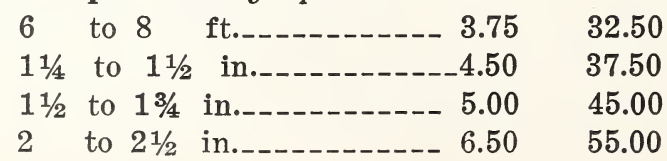


Quercus.

palustris. Pin Oak. each

per 10

per 100

6 to 8 ft._-_-_-_-_-_-_ $3.25 \quad 27.50$

$1 \frac{1}{4}$ to $1 \frac{1}{2}$ in..-_-_-_-_-_ $4.50 \quad 40.00$

$1 \frac{1}{2}$ to $13 / 4$ in.-_-_-_-_- $5.00 \quad 47.50$

$13 / 4$ to 2 in.-_-_-_-_-_ $6.50 \quad 55.00$

2 to $2 \frac{1}{2}$ in..-_-_-_-_- $7.50 \quad 65.00$

$2 \frac{1}{2}$ to 3 in.-_-_-_-_-_- $10.00 \quad 75.00$

3 to $31 / 2$ in.--_-_-_-_- 12.50

$31 / 2$ to 4 in.--_-_-_-_-_-_ 17.50

4 to 5 in...... 25.00

phellos. Willow Oak.

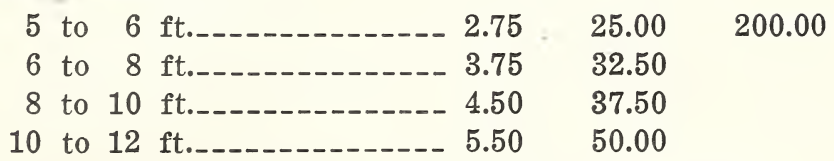

prinus. Chestnut Oak.

\begin{tabular}{|c|c|c|c|}
\hline 6 & to & ft._-_-_-_-_- 2.50 & 22.50 \\
\hline 8 & to 10 & ft._-_-_-_-_--- 3.25 & 25.00 \\
\hline $11 / 4$ & to $1 \frac{1}{2}$ & in._-_-_- 3.75 & 32.50 \\
\hline $11 / 2$ & $13 / 4$ & in..... 5.00 & 45.00 \\
\hline $13 / 4$ & to 2 & in...- 6.50 & 50.00 \\
\hline 2 & to $2 \frac{1}{2}$ & in._-non 7.50 & \\
\hline $21 / 2$ & to 3 & in. & \\
\hline
\end{tabular}

robur. English Oak.

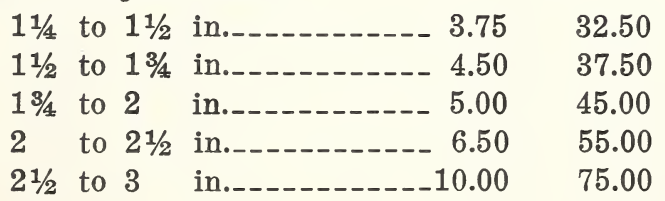

rubra. Red Oak.

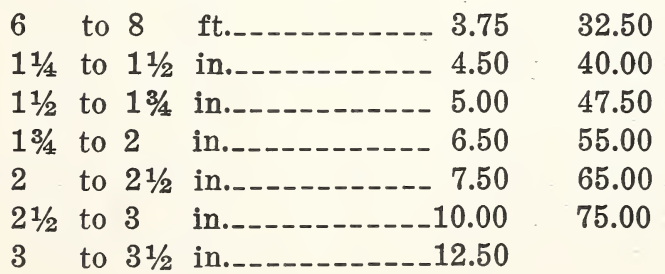


Salix.

babylonica salamoni. Salamon Weeping Willow.

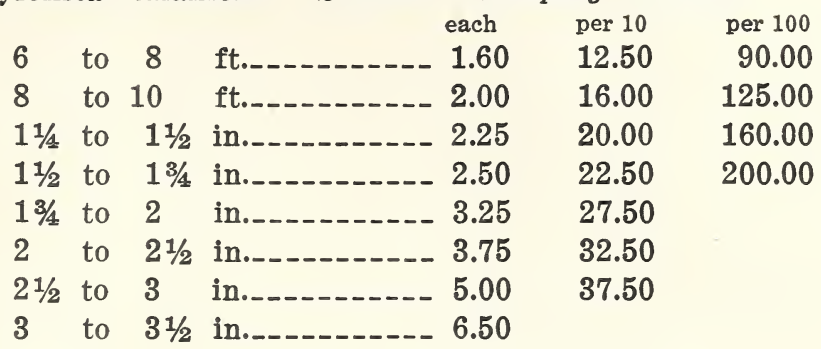

caprea. Goat Willow.

5 to $6 \mathrm{ft} . \ldots$
6 to $8 \mathrm{ft}$.
8 to $10 \mathrm{ft}$.

discolor. Pussy Willow.

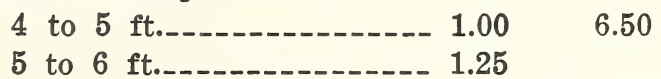

pentandra. Laurel Willow.

6 to 8 ft._.

$12.50 \quad 90.00$

8 to 10 ft._._. $2.00 \quad 16.00 \quad 125.00$

$1 \frac{1}{4}$ to $1 \frac{1}{2}$ in._._._. $2.25 \quad 20.00$

$11 / 2$ to $13 / 4$ in...... $2.50 \quad 22.50$

$13 / 4$ to 2 in._._._. $3.25 \quad 27.50$

regalis. Royal Willow.

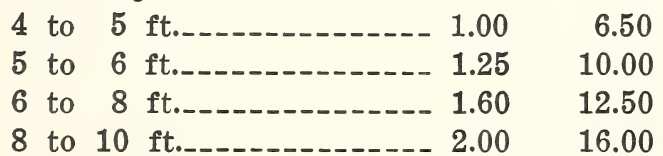

rosmarinifolia. (See Shrubs).

sieboldiana. Siebold Willow.

5 to $6 \mathrm{ft.}$

6 to $8 \mathrm{ft.}$

8 to $10 \mathrm{ft} . \ldots$

vitellina. Golden Willow.

\begin{tabular}{|c|c|c|c|c|}
\hline 6 & to & ft.._- & 10.00 & 75.00 \\
\hline 0 & to 10 & ft._n- 1.60 & 12.50 & 90.00 \\
\hline $1 / 4$ & $11 / 2$ & in. $\ldots \ldots$ & 16.00 & 125.00 \\
\hline $1 / 2$ & $13 / 4$ & in._. & 20.00 & 160.00 \\
\hline . & to & in. $\ldots \ldots$ & 22.50 & 200.00 \\
\hline & to $21 / 2$ & in. & 27.50 & \\
\hline & to 3 & in. & 32.50 & \\
\hline
\end{tabular}


Salix.

vitellina britzensis. Bronze Golden Willow.

\begin{tabular}{|c|c|c|c|c|}
\hline 5 & to & $\begin{array}{ll} & \text { each } \\
\text { ft. } & 1.00\end{array}$ & $\begin{array}{r}\text { per } 10 \\
7.50\end{array}$ & $\begin{array}{r}\text { per } 100 \\
65.00\end{array}$ \\
\hline & to & ft._-_-_ & 10.00 & 75.00 \\
\hline & to 10 & ft._. & 12.50 & 90.00 \\
\hline & $13 / 4$ & in.-_- 2.25 & 20.00 & \\
\hline & to 2 & in.--_-n--- 2.50 & 22.50 & \\
\hline
\end{tabular}

Sassafras variifolium. Sassafras.

4 to 5 ft._.
5 to 6 ft._.
6 to 8 ft._-_

Sorbus americana. American Mountain Ash. 6 to $8 \mathrm{ft.}$.

aria latifolia. White Beam-tree.

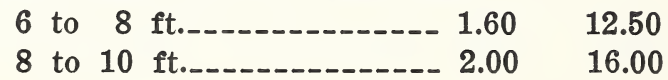

aucuparia. European Mountain Ash.

\begin{tabular}{|c|c|c|c|c|}
\hline 6 & to & ft._- & 16.00 & 125.00 \\
\hline 8 & to 10 & -2.50 & 20.00 & 160.00 \\
\hline $1 / 4$ & $11 / 2$ & in.......- & 25.00 & 225.00 \\
\hline $1 /$ & $13 / 4$ & in._-__- 3.75 & 32.50 & \\
\hline & to & in. & 37.50 & \\
\hline & $21 / 2$ & in & & \\
\hline
\end{tabular}

quercifolia. Oak-leaf Mountain Ash.

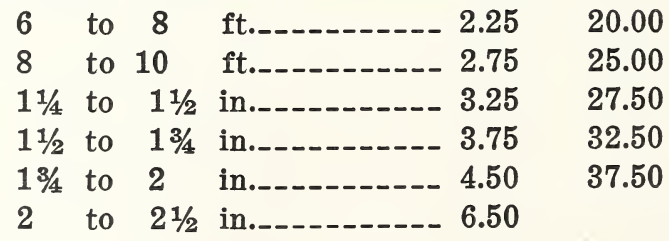

Syringa japonica. (See Deciduous Shrubs).

Taxodium distichum. Common Baldcypress.

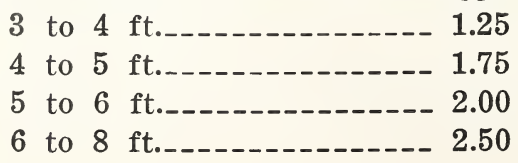


Tilia americana. American Linden. each

6 to 8 ft._._._._._. 2.75

8 to 10 ft._.-_-_-_-_- 3.75

$11 / 4$ to $11 / 2$ in........... 4.50

$11 / 2$ to $13 / 4$ in........... 5.00

$13 / 4$ to 2 in........... 6.50

2 to $21 / 2$ in......... 7.50

$2 \frac{1}{2}$ to 3 in._-_._._. 10.00

3 to $3 \frac{1}{2}$ in._-_-_-_ 12.50

$31 / 2$ to 4 in._-_-_-_-_ 17.50

4 to 5

25.00 per 10

25.00

35.00

40.00

45.00

50.00

65.00

75.00

euchlora. Crimean Linden.

\begin{tabular}{|c|c|c|c|}
\hline $1 / 4$ to & $11 / 2$ & in._-__- 4.50 & 40.00 \\
\hline $1 \frac{1 / 2}{2}$ to & $13 / 4$ & in._-_-_-_- 5.00 & 45.00 \\
\hline $3 / 4$ to & 2 & -- 6.50 & 50.00 \\
\hline & $21 / 2$ & $\ldots$ & 65.00 \\
\hline 10 & 3 & in. 10.00 & \\
\hline & $31 / 2$ & in. & \\
\hline
\end{tabular}

platyphyllos. Bigleaf European Linden.
6 to 8
ft.
2.75
25.00
8 to 10
3.75
35.00
$11 / 4$ to $1 \frac{1}{2}$ in
4.50
40.00
$11 / 2$ to $1 \frac{3}{4}$ in
5.00
45.00
$13 / 4$ to 2 in.
6.50
50.00
2 to $2 \frac{1}{2}$ in
7.50
65.00
$21 / 2$ to 3
10.00
75.00

tomentosa. Silver Linden.

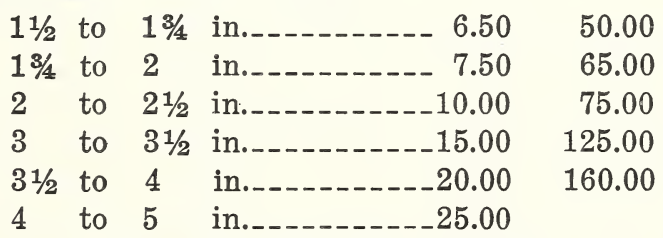

vulgaris. Common European Linden.

\begin{tabular}{|c|c|c|c|c|}
\hline 6 & to & ft.___- & 25.00 & \\
\hline 8 & to 10 & -3.75 & 35.00 & \\
\hline $1 / 4$ & $11 / 2$ & in..-... 4.50 & 40.00 & 375.00 \\
\hline $1 / 2$ & $13 / 4$ & in._-_- & 45.00 & 400.00 \\
\hline $3 / 4$ & to & in._. 6.50 & 50.00 & 475.00 \\
\hline & $21 / 2$ & in.-.-.-. 7.50 & 65.00 & 550.00 \\
\hline $1 / 2$ & to & in.. 10.00 & 75.00 & \\
\hline & $31 / 2$ & in.--n- 12.50 & 100.00 & \\
\hline & 4 & in.-...- 17.50 & & \\
\hline & 5 & 1. & & \\
\hline
\end{tabular}


Ulmus americana. American Elm.

\begin{tabular}{|c|c|c|c|c|}
\hline 8 & to 10 & $\begin{array}{rr} & \text { each } \\
\text { ft._. } & 3.25\end{array}$ & $\begin{array}{l}\text { per } 10 \\
25.00\end{array}$ & $\begin{array}{r}\text { per } 100 \\
200.00\end{array}$ \\
\hline $11 / 4$ & to $11 / 2$ & in._-_- 3.50 & 27.50 & 250.00 \\
\hline $11 / 2$ & $13 / 4$ & in...... 4.50 & 37.50 & 325.00 \\
\hline $13 / 4$ & to & in.-_- 5.50 & 45.00 & 375.00 \\
\hline . & to $2 \frac{1}{2}$ & in.-_- 7.50 & 55.00 & \\
\hline $1 / 2$ & to & in._-_- 10.00 & 75.00 & \\
\hline & $31 / 2$ & in.-_-n- 12.50 & & \\
\hline $1 / 2$ & to 4 & in. & & \\
\hline
\end{tabular}

americana moline. Moline Elm.

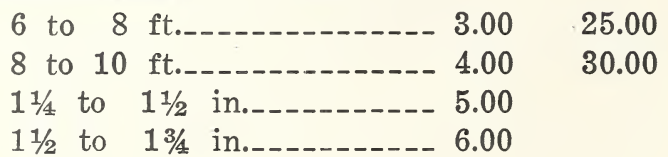

americana vase-shaped.

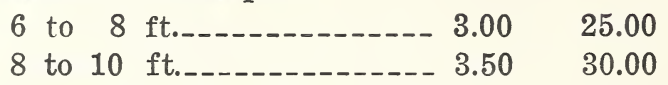
campestris. English Elm.

\begin{tabular}{|c|c|c|c|}
\hline & to & ft._-_-_-_- 2.75 & 22.50 \\
\hline & to 10 & -3.50 & 27.50 \\
\hline $1 / 4$ & $11 / 2$ & ---3.75 & 32.50 \\
\hline 12 & $13 / 4$ & in...- 5 . & 0.00 \\
\hline $3 / 4$ & to & in.._- 6.50 & 50.00 \\
\hline & $21 / 2$ & in. & 65.00 \\
\hline 72 & 3 & -10.00 & 75.00 \\
\hline & $31 / 2$ & in...... & 100.00 \\
\hline
\end{tabular}

campestris klemmeri. Klemmer Elm.

6 to 8 ft._-_-_-_-_-_-_ 5.00

campestris latifolia. Belgian Elm.
6 to
5.00
8 to $10 \mathrm{ft}$.
6.00

campestris monumentalis. Monument Elm.

\begin{tabular}{|c|c|c|}
\hline & to & \\
\hline & to 10 & ft... \\
\hline & $11 / 2$ & in. \\
\hline & $13 / 4$ & in. \\
\hline & 2 & 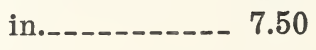 \\
\hline & $21 / 2$ & . \\
\hline
\end{tabular}

campestris purpurea. Purpleleaf English Elm.

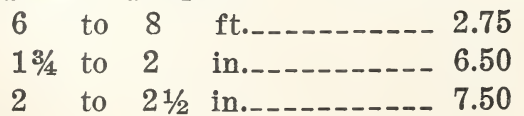




\section{Ulmus}

campestris vegeta. Huntingdon Elm.

\begin{tabular}{|c|c|c|c|c|}
\hline & & each & per 10 & $\begin{array}{r}\text { per } 100 \\
225.00\end{array}$ \\
\hline 8 & to 10 & ft._-_- & 27.50 & 225.00 \\
\hline $11 / 4$ & $11 / 2$ & -_- 3.75 & 32.50 & 250.00 \\
\hline $11 / 2$ & $13 / 4$ & 5.00 & 40.00 & 325.00 \\
\hline $13 / 4$ & to 2 & in. & 50.00 & \\
\hline 2 & to $21 / 2$ & in.._. & 65.00 & \\
\hline $21 / 2$ & to & in. 10.00 & 75.00 & \\
\hline 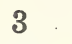 & $31 / 2$ & in._. & 100.00 & \\
\hline $31 / 2$ & to 4 & in._-_. 17.50 & & \\
\hline & 5 & in. & & \\
\hline
\end{tabular}

fulva. Slippery Elm.

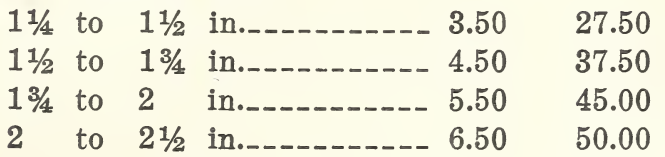

glabra. Scotch Elm.

\begin{tabular}{|c|c|c|c|c|}
\hline 8 & to 10 & ft._. & 27.50 & 225.00 \\
\hline $11 / 4$ & $11 / 2$ & 3.75 & 32.50 & 250.00 \\
\hline $1 / 2$ & $13 / 4$ & in._. 5.00 & 40.00 & 325.00 \\
\hline $3 / 4 \mathrm{t}$ & to & in. & 50.00 & 375.00 \\
\hline & $21 / 2$ & in. & 65.00 & \\
\hline $1 / 2$ & 3 & in._- 10.00 & 75.00 & \\
\hline & $31 / 2$ & - 12.50 & 100.00 & \\
\hline
\end{tabular}

glabra camperdowni. Camperdown Elm.

6 ft. stem_-____-_._- 5.00

japonica. Japanese Elm.

6 to 8 ft._-_._-_-_ 5.00

8 to 10 ft......... 6.50

$13 / 4$ to 2 in.

2 to $2 \frac{1}{2}$ in.

parviflora. Chinese Elm.

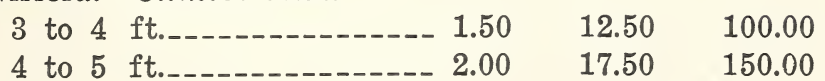

racemosa. Rock Elm.

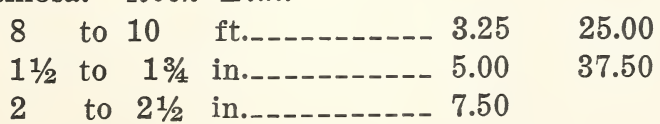

Zelkova serrata. Sawleaf Zelkova.

3 to 4 ft._._._._. $1.25 \quad 10.00 \quad 75.00$ 


\section{Fruit Trees}

We are able to supply all the leading varieties.

\begin{tabular}{|c|c|c|c|}
\hline Apples, Crab, & 5 to $7 \mathrm{ft.} \quad \begin{array}{c}\text { each } \\
1.25\end{array}$ & per 10 & per 100 \\
\hline $\begin{array}{l}\text { Apples, Crab, } \\
\text { Dwarf, }\end{array}$ & 5 to $7 \mathrm{ft}$. & 12.50 & \\
\hline Standard, & 5 to $7 \mathrm{ft.}$ & 10.00 & \\
\hline Cherry, Sour, & 5 to $7 \mathrm{ft.}$------ 1.70 & 16.00 & \\
\hline Sweet, & 5 to $7 \mathrm{ft.}$.------ 1.70 & 16.00 & \\
\hline Peaches. & 5 to $7 \mathrm{ft}$._--- 1.00 & 6.50 & \\
\hline Pears, Dwarf, & 5 to $6 \mathrm{ft.}$ & 12.50 & \\
\hline Standard, & 5 to $7 \mathrm{ft.}$. & 15.00 & \\
\hline \multirow{2}{*}{$\begin{array}{l}\text { Plums, } \\
\text { Quinces, }\end{array}$} & 5 to $7 \mathrm{ft.}$. & 17.50 & \\
\hline & 4 to $5 \mathrm{ft.} .----1.70$ & 15.00 & \\
\hline & Small Fruits & & \\
\hline \multicolumn{3}{|c|}{ Asparagus - } & 6.00 \\
\hline \multicolumn{2}{|c|}{ Blackberries - } & 1.00 & 9.50 \\
\hline \multicolumn{2}{|c|}{ Currants } & 5.00 & 35.00 \\
\hline \multicolumn{2}{|c|}{ Gooseberries $\quad-1-60$} & 5.00 & 35.00 \\
\hline \multicolumn{2}{|c|}{ Grapes, 3 yr. strong $\ldots$} & 4.00 & 30.00 \\
\hline \multicolumn{2}{|c|}{ Raspberries - } & 1.00 & 9.50 \\
\hline \multicolumn{2}{|c|}{ Rhubarb - } & 2.00 & 12.00 \\
\hline \multicolumn{2}{|c|}{ Strawberries - } & .75 & 6.00 \\
\hline
\end{tabular}

\section{Deciduous Shrubs}

The figures printed in italics following each variety, indicate the average height of the plant at maturity.

Abelia rupestris grandiflora.

$$
\text { each per } 10 \text { per } 100
$$

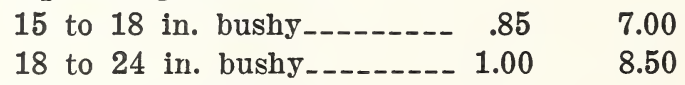

Acanthopanax pentaphyllum.

Five-leaved Aralia. 10'

2 to $3 \mathrm{ft.}$

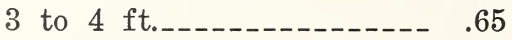

4 to 5 ft._-_-_-_-_-_-_- .75

6.00

5 to $6 \mathrm{ft.}$.

ricinifolium. Castor Aralia. 25'

$$
\begin{aligned}
& 8 \text { to } 10 \text { ft._-_-_-_-_-_-_ } 2.25 \quad 16.00 \\
& 10 \text { to } 12 \text { ft._-_-_-_-_-_-_ } 3.50 \quad 25.00
\end{aligned}
$$

Althea. (See Hibiscus).

Alnus rugosa. Hazel Alder. 10'

2 to $3 \mathrm{ft}$ 
Amelanchier canadensis. Downy Shadbush. 10'

2 to 3 ft.-_-_-_-_-_-_-- $\begin{array}{rrrr}\text { each } & \text { per } 10 & \text { per } 100 \\ & & 4.50 & 40.00\end{array}$

laevis. Allegheny Serviceberry. 20'

2 to $3 \mathrm{ft}$.

vulgaris. European Serviceberry. 25'

2 to 3 ft._-_-_-_-_-_- $.65 \quad 4.50 \quad 40.00$

Amorpha canescens. Lead Plant. 2'

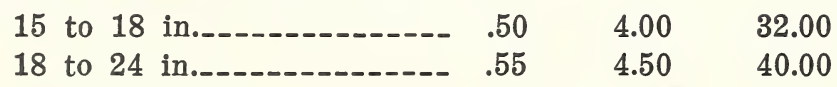

fruticosa. Indigobush. 10'

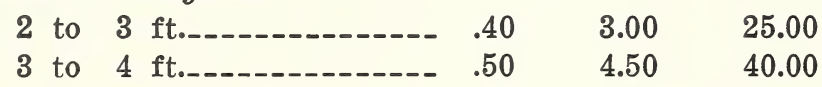

Amygdalus nana georgica. Russian Almond. $6^{\prime}$

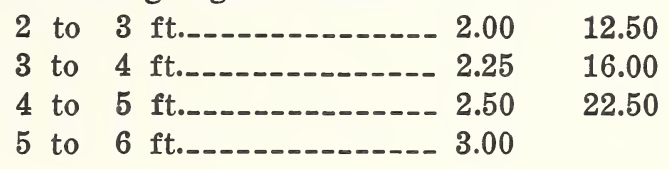

Aralia japonica. Angelica Tree. $25^{\prime}$

\begin{tabular}{|c|c|c|c|}
\hline & to & 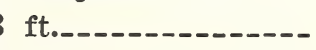 & .50 \\
\hline 3 & to & 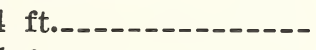 & .65 \\
\hline & 5 & 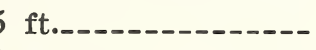 & .75 \\
\hline & 6 & 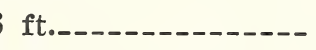 & $1: 25$ \\
\hline & 8 & 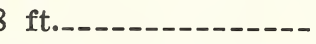 & 1.60 \\
\hline & 10 & 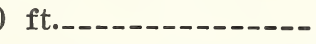 & 3.75 \\
\hline
\end{tabular}

mandshurica. Manchurian Aralia. 25'

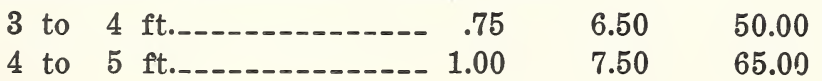

pentaphyllum. (See Acanthopanax).

spinosa. Devil's Walkingstick. 25'

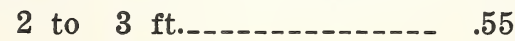

3 to 4 ft.-_-_-

$4.50 \quad 40.00$

4 to $5 \mathrm{ft.}$.-_-_- 1.00

$5.50 \quad 50.00$

5 to $6 \mathrm{ft.}$.

$7.50 \quad 60.00$

6 to $8 \mathrm{ft.}$

$10.00 \quad 80.00$

8 to $10 \mathrm{ft}$. clumps_-_---- 5.00

10 to $12 \mathrm{ft}$. clumps_-_-_--- 6.50 
Aronia arbutifolia. Red Chokeberry. $8^{\prime}$

\begin{tabular}{|c|c|c|c|c|}
\hline & & each & per 10 & per 100 \\
\hline 2 to & $3 \mathrm{ft} . \ldots$ & .65 & $5.5 \mathrm{C}$ & 50.00 \\
\hline 3 to & $4 \mathrm{ft}$. & .80 & 7.00 & 65.00 \\
\hline 4 to & 5 ft....- & 1.25 & 10.00 & 75.00 \\
\hline to & $6 \mathrm{ft} . \ldots$ & 1.60 & 12.50 & \\
\hline
\end{tabular}

atropurpurea Purple Chokeberry. $8^{\prime}$

\begin{tabular}{|c|c|c|}
\hline 2 to & 3 ft._- & 5.50 \\
\hline to & $--n-n-n$ & 7.00 \\
\hline to & $5 \mathrm{ft}$. & 10.00 \\
\hline
\end{tabular}

melanocarpa. Black Chokeberry. 10'

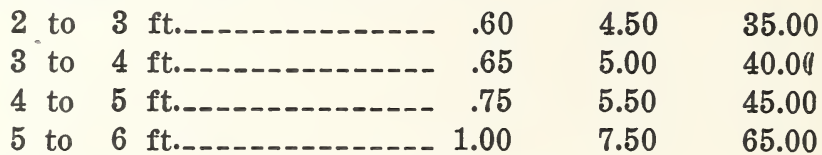

melanocarpa elata. Glossy Chokeberry. 6 $^{\prime}$

2 to $3 \mathrm{ft.} . \ldots .60$

32.00

3 to $4 \mathrm{ft.} . \ldots 5$

5.00

40.00

4 to $5 \mathrm{ft.}$

5.50

45.00

Azalea calendulacea. Flame Azalea. $6^{\prime}$ 2 to $3 \mathrm{ft.}$.

$30.00 \quad 275.00$

canescens. Piedmont Azalea. $6^{\prime}$

2 to 3 ft._.___B. \& B. $3.50 \quad 27.50$

250.00

nudiflora. Pinksterbloom. 4 '

2 to 3 ft.____B. \& B. $3.50 \quad 27.50 \quad 250.00$

viscosa. Swamp Azalea. $6^{\prime}$

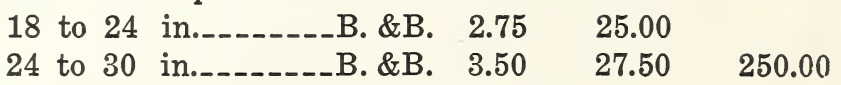

Baccharis halimifolia. Groundselbush. 10'

2 to $3 \mathrm{ft.}$

5.50

50.00

3 to $4 \mathrm{ft.}$.

6.50

4 to $5 \mathrm{ft} . \ldots \ldots$

7.50

5 to

$6 \mathrm{ft.}$

10.00

Benzoin aestivale. Spice Bush. 12'
2 to
$3 \mathrm{ft}$.
.75
6.00
3 to $4 \mathrm{ft}$
4 to
1.50
12.50
5 to
2.25
20.00
6 to
$6 \mathrm{ft}$
3.00
25.00

50.00

Berberis ilicifolia. Holly Barberry. 4'

18 to 24 in.._- 1.50 
Berberis

thunbergi. Japanese Barberry. $4^{\prime}$

\begin{tabular}{|c|c|c|c|c|c|}
\hline & & & each & per 10 & per 100 \\
\hline 15 & to 18 & in. & .30 & 2.00 & 15.00 \\
\hline 8 & to 24 & in. & .40 & 2.50 & 20.00 \\
\hline & to 30 & in. & .50 & 4.00 & 30.0 \\
\hline 2 & to $2 \frac{1}{2}$ & ft. specimens_- & .75 & 6.50 & \\
\hline 21 & to 3 & ft. specimens_- & 1.00 & 8.50 & \\
\hline 3 & to $31 / 2$ & ft. specimens_- & 1.25 & 11.50 & \\
\hline
\end{tabular}

thunbergi minor. Box Barberry.

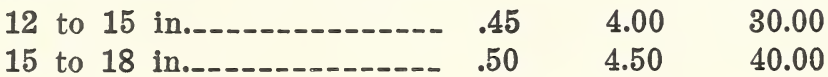

thunbergi pluriflora. $5^{\prime}$

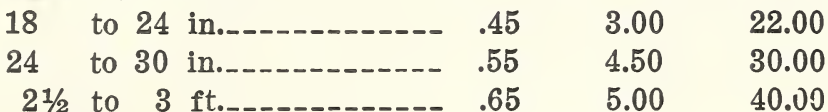

wilsonae. Wilson Barberry.

18 to 24 in.

2 to $3 \mathrm{ft.}$

Berchemia racemosa. Japanese Supplejack. ' 3

18 to 24 in... $75 \quad 5.00$

Buddleia davidi. Orange-eye Butterfly Bush. 5'

2 to $3 \mathrm{ft.} . \ldots .00$

25.00

3 to $4 \mathrm{ft.}$

davidi veitchi. Veitch Butterfly Bush. 5'

2 to $3 \mathrm{ft.} . \ldots .45 \quad 3.00 \quad 25.00$

3 to 4 ft._._. $65 \quad 4.50 \quad 30.00$

farquhari.

2 to $3 \mathrm{ft.}$

intermedia. Wisteria Butterfly Bush. $5^{\prime}$

2 to 3 ft._.

3 to $4 \mathrm{ft.}$.

lindleyana. Lindley Butterfly Bush. $5^{\prime}$

2 to $3 \mathrm{ft.}$.

3 to 4 ft._._. $65 \quad 4.50 \quad 30.00$

Callicarpa purpurea. Chinese Beautyberry. 4'

18 to 24 in.... $50 \quad 4.00 \quad 32.00$

2 to 3 ft..... $65 \quad 5.00 \quad 45.00$

japonica. Japanese Beautyberry. 4'

18 to 24 in.... $65 \quad 5.00 \quad 45.00$

Calycanthus floridus. Sweet Shrub. 5'

2 to $2 \frac{1}{2}$ ft.

$21 / 2$ to 3 ft._. 350 
Caragana arborescens. Siberian Peatree. 15'

\begin{tabular}{|c|c|c|}
\hline & each & per 10 \\
\hline 2 to $3 \mathrm{ft}$. & .50 & 4.00 \\
\hline 3 to $4 \mathrm{ft}$. & .65 & 4.50 \\
\hline 4 to $5 \mathrm{ft}$. & .75 & 6.50 \\
\hline 5 to $6 \mathrm{ft}$. & 1.25 & 10.00 \\
\hline
\end{tabular}

Caryopteris incana. Bluebeard. 4'

\begin{tabular}{|c|c|}
\hline-- & .50 \\
\hline - - - - & .65 \\
\hline
\end{tabular}

Ceanothus americanus. Jersey Tea. ${ }^{\prime}$

\begin{tabular}{|c|c|}
\hline $00=2$ & .55 \\
\hline to $3 \mathrm{ft}$. & .65 \\
\hline
\end{tabular}

Cephalanthus occidentalis. Button Bush. $6^{\prime}$

\begin{tabular}{|c|c|c|}
\hline to $3 \mathrm{ft}$ & .50 & 4.50 \\
\hline to $4 \mathrm{ft.} .---$ & .60 & 5.00 \\
\hline to $5 \mathrm{ft.}$ & .75 & 6.00 \\
\hline
\end{tabular}

Chionanthus virginica. White Fringe. 25'

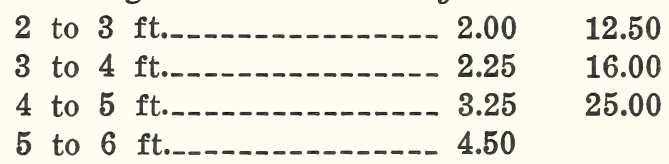

Clerodendron trichotomum. Harlequin Glorybower. 6' 4 to $5 \mathrm{ft.}$.

Clethra alnifolia. Sweet Pepper Bush. 5'

\begin{tabular}{|c|c|c|c|c|}
\hline 18 & to 24 & in. & .55 & 4.00 \\
\hline 24 & to & in.--...- & .65 & 5.00 \\
\hline $21 / 2$ & to & ft...-..- & .75 & 5.50 \\
\hline
\end{tabular}

barbinervis. Tree Clethra. $5^{\prime}$

18 to 24 in.-_-_- $1.00 \quad 7.50$

Colutea arborescens. Bladder Senna. 10'

\begin{tabular}{|c|c|c|}
\hline to $3 \mathrm{ft}$. & .50 & 4.00 \\
\hline $4 \mathrm{ft}$. & .65 & 4.50 \\
\hline to $5 \mathrm{ft.}$ & .75 & 5.50 \\
\hline
\end{tabular}

Comptonia asplenifolia. Sweetfern. $3^{\prime}$

\begin{tabular}{|c|c|}
\hline 11. & 50 \\
\hline $3 \mathrm{ft.}$ & .65 \\
\hline
\end{tabular}

Cornus alba. Tatarian Dogwood. 10'

\begin{tabular}{|c|c|c|c|}
\hline 2 to $3 \mathrm{ft}$. & .45 & 3.00 & 20.00 \\
\hline 3 to $4 \mathrm{ft}$. & .50 & 3.50 & 25.00 \\
\hline 4 to $5 \mathrm{ft.}$ & .65 & 5.00 & 40.00 \\
\hline 5 to $6 \mathrm{ft}$. & .75 & 5.50 & 45.00 \\
\hline to $8 \mathrm{ft.}$ & 1.00 & 6.50 & 50.00 \\
\hline
\end{tabular}




\section{Cornus}

alba elegantissima. Silverblotch Dogwood. $6^{\prime}$

\begin{tabular}{|c|c|c|}
\hline 2 to $3 \mathrm{ft}$. & $\begin{array}{r}\text { each } \\
.55\end{array}$ & $\begin{array}{r}\text { per } 10 \\
4.50\end{array}$ \\
\hline 3 to $4 \mathrm{ft}$. & .75 & 6.00 \\
\hline to $5 \mathrm{ft}$ & 1.00 & 7.50 \\
\hline to $6 \mathrm{ft}$. & 1.25 & 10.00 \\
\hline
\end{tabular}

alba sibirica. Coral Dogwood.

$\begin{array}{lllll}2 \text { to } 3 \mathrm{ft} . & .45 & 3.00 & 20.00 \\ 3 \text { to } 4 \mathrm{ft.} & .50 & 3.50 & 25.00 \\ 4 \text { to } 5 \mathrm{ft.} & \\ 5 \text { to } 6 \mathrm{ft.} & .65 & 5.00 & 40.00 \\ & \end{array}$

alba spaethi aurea. Golden variegated Dogwood. $8^{\prime}$

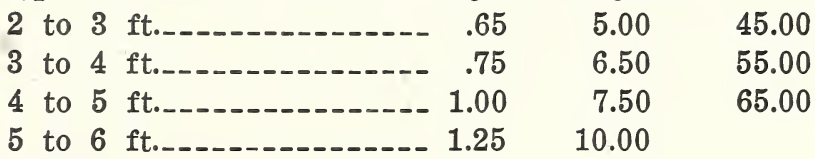

alternifolia. Pagoda Dogwood. 20'

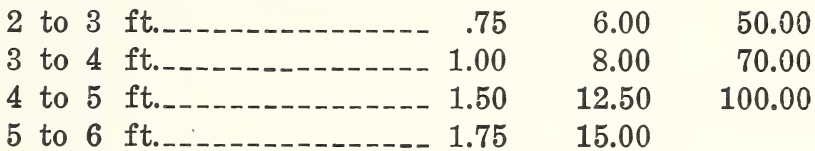

amomum syn. sericea. Silky Dogwood. 10'

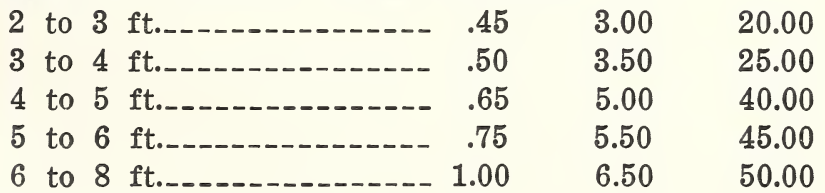

baileyi. Bailey Dogwood. 10'

2 to 3 ft._.
3 to 4 ft._. 5 .
4 to 5 ft.

kousa. Kousa Dogwood. 20'
2 to $3 \mathrm{ft}$.
$1.25 \quad 10.00$
3 to 4 ft......... 1.60
12.50
4 to $5 \mathrm{ft}$.

mas. Cornelian Cherry. 20'

2 to $3 \mathrm{ft} . \ldots 1.25 \quad 10.00$

3 to $4 \mathrm{ft.}$.

paniculata. Gray Dogwood. 15'

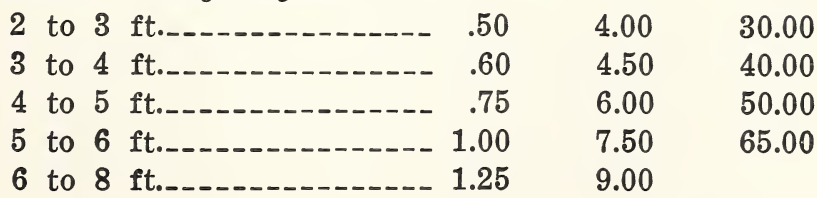




\section{Cornus.}

sanguinea. Bloodtwig Dogwood.

\begin{tabular}{|c|c|c|c|}
\hline & each & per 10 & per 100 \\
\hline to $3 \mathrm{ft}$. & .4 & 3.00 & 20.00 \\
\hline to $4 \mathrm{ft}$. & .50 & 3.50 & 25.00 \\
\hline 5 ft.-_- & .60 & 5.00 & 40.00 \\
\hline $6 \mathrm{ft}$. & .75 & 6.00 & 50.00 \\
\hline
\end{tabular}

sanguinea viridissima. Greentwig Dogwood. 10'

\begin{tabular}{|c|c|c|}
\hline 2 to $3 \mathrm{ft}$. & .50 & 4.00 \\
\hline 3 to $4 \mathrm{ft}$. & .65 & 5.00 \\
\hline ft..-n-n. & .75 & 6.00 \\
\hline to $6 \mathrm{ft}$. & 1.25 & 9.50 \\
\hline
\end{tabular}

stolonifera. Red Osier Dogwood. $8^{\prime}$

\begin{tabular}{|c|c|c|}
\hline 2 to $3 \mathrm{ft}$. & .45 & 3.00 \\
\hline 3 to $4 \mathrm{ft}$ & .50 & 3.50 \\
\hline to $5 \mathrm{ft}$ & .65 & 5.00 \\
\hline to $6 \mathrm{ft}$. & .75 & 5.50 \\
\hline $8 \mathrm{ft.} \ldots \ldots$ & 1.00 & 7.50 \\
\hline 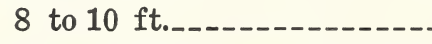 & 1.50 & 12.50 \\
\hline
\end{tabular}

stolonifera flaviramea. Goldentwig Dogwood. $8^{\prime}$

\begin{tabular}{|c|c|c|}
\hline 2 to $3 \mathrm{ft}$. & .45 & 3.50 \\
\hline 3 to $4 \mathrm{ft}$. & .50 & 4.00 \\
\hline to $5 \mathrm{ft}$. & .65 & 5.00 \\
\hline
\end{tabular}

Corylus americana. American Hazelnut. 10'

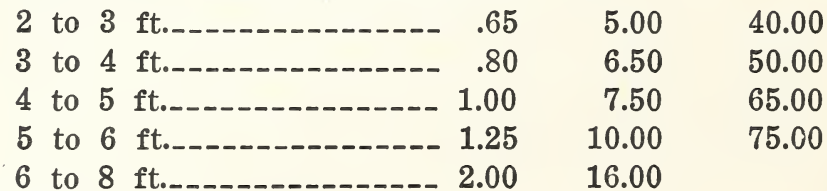

avellana. Filbert. 15'

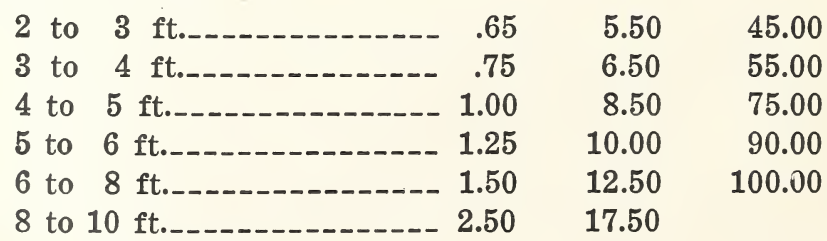

rostrata. Beaked Hazelnut. $6^{\prime}$

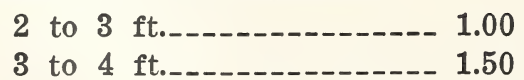

Cotoneaster acutifolia. Blackfruited Quinceberry. 12'

\begin{tabular}{|c|c|c|}
\hline 3 ft. & .50 & 4.00 \\
\hline 4 ft. & .60 & 4.50 \\
\hline 5 ft.-.-- & 1.00 & 7.50 \\
\hline to $6 \mathrm{ft.}$ & 1.25 & 10.00 \\
\hline
\end{tabular}




\section{Cotoneaster}

adpressa. Creeping Cotoneaster. 2'

15 to 18 in from pots each per 10

per 100 ambigua. $6^{\prime}$

2 to $3 \mathrm{ft}$.

7.50

65.00

applanata. $6^{\prime}$

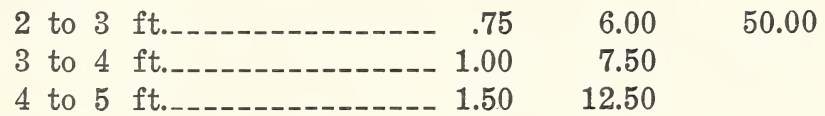

divaricata. Spreading Cotoneaster. $6^{\prime}$

2 to 3 ft._._._. $75 \quad 6.00$

50.00

3 to $4 \mathrm{ft}$

1.00

7.50

foveolata. Scarlet fruited Quinceberry. 10'

2 to $3 \mathrm{ft}$.

6.00

3 to $4 \mathrm{ft}$

7.50

4 to $5 \mathrm{ft}$.

1.00

12.50

horizontalis. Prostrate Quinceberry. ' ${ }^{\prime}$

15 to $18 \mathrm{in}$. spread from pots 1.50

12.50

hupehensis. Hupen Cotoneaster. $5^{\prime}$
2 to $3 \mathrm{ft.}$.
7.50
3 to $4 \mathrm{ft}$.
4 to $5 \mathrm{f}$
12.50

65.00

lucida. $12^{\prime}$

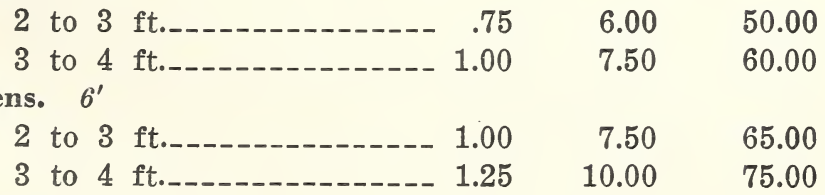

obscura. $10^{\prime}$

2 to $3 \mathrm{ft}$.

65.00

3 to $4 \mathrm{ft}$...... $1.25 \quad 10.00$

wilsoni. Wilson Cotoneaster. $5^{\prime}$

\begin{tabular}{|c|c|}
\hline to $3 \mathrm{ft}$. & 7.50 \\
\hline to $4 \mathrm{ft}$. & 10.00 \\
\hline
\end{tabular}

Cydonia japonica. Flowering Quince. $5^{\prime}$

2 to $3 \mathrm{ft} .-(-60$

$5.00 \quad 40.00$

3 to $4 \mathrm{ft.}$

japonica pygmaea. Dwarf Jap. Quince. 3'

18 to 24 in.
2 to 3 ft.

60.00

japonica umbilicata. Naval Flowering Quince. $5^{\prime}$

2 to 3 ft._.
3 to 4 ft._.
4 to 5 ft._.


Cydonia.

maulei. Lesser Flowering Quince. $\quad 5^{\prime}$

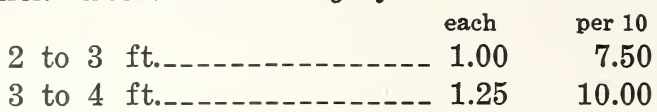

per 100

Cytisus hirsutus. $3^{\prime}$

2 to $3 \mathrm{ft.}$

Daphne mezereum. February Daphne. 4'

15 to 18 in...... B. \& B. 1.50

18 to 24 in. 2.00

Desmodium. (See Lespedeza).

Deutzia gracilis. Slender Deutzia. 3'

\begin{tabular}{|c|c|c|}
\hline to $18 \mathrm{in}$ & .45 & 3.50 \\
\hline to 24 in. & .55 & 4.50 \\
\hline to 30 in. & .65 & 5.00 \\
\hline
\end{tabular}

gracilis campanulata. Bellflower Deutzia. $5^{\prime}$

18 to 24 in....... $.50 \quad 4.00$

24 to 30 in..... $.60 \quad 5.00$

30.00

$21 / 2$ to $3 \mathrm{ft} . \ldots \ldots .00$

40.00

3 to $4 \mathrm{ft.}$

7.50

gracilis carminea. Carmine Deutzia. ' 4'

18 to 24 in....... .60

$5.00 \quad 40.00$

2 to 3 ft........ 70

$6.00 \quad 50.60$

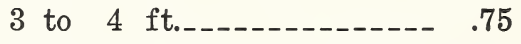

$6.50 \quad 60.00$

gracilis rosea. Rose-panicle Deutzia. 4'

18 to 24 in....... .60

5.00

40.00

24 to 30 in..... 70

6.00

50.00

$21 / 2$ to $3 \mathrm{ft.} . \ldots .+75$

6.50

60.00

3 to $4 \mathrm{ft.}$.

gracilis venusta. White-panicle Deutzia. $5^{\prime}$

18 to 24 in...... $.50 \quad 4.00$

24 to 30 in...... $.60 \quad 5.00$

30.00

$21 / 2$ to 3 ft._._._._. $.75 \quad 6.00$

40.00

lemoinei. Lemoine Deutzia. $5^{\prime}$

18 to 24 in........... 45

$3.50 \quad 25.00$

24 to 30 in.-...-...... .55

$4.50 \quad 35.00$

$21 / 2$ to $3 \mathrm{ft.}$

$5.50 \quad 45.00$

lemoine avalanche. Avalanche Deutzia. 4'

2 to $2 \frac{1}{2}$ ft._._._. $.75 \quad 6.00$

50.00

$21 / 2$ to 3 ft._._. $1.00 \quad 7.50$

parviflora. Mongolian Deutzia. $5^{\prime}$

$\begin{array}{rrrrr}18 \text { to } 24 \text { in. } & \\ 2 \text { to } 3 \text { ft. } & .50 & 4.00 & 30.00 \\ & \end{array}$




\section{Deutzia}

scabra. Fuzzy Deutzia. 12' each

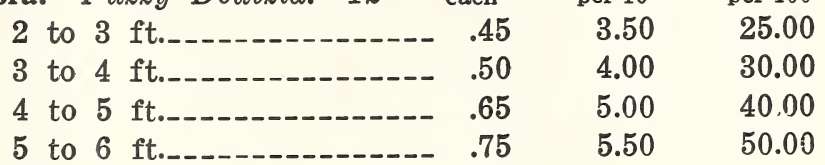

scabra candidissima. Snowflake Deutzia. 12'

2 to $3 \mathrm{ft.}$.

25.00

3 to $4 \mathrm{ft.}$

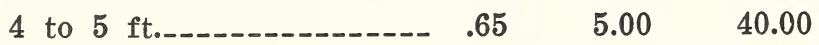

5 to 6 ft._._.

scabra Pride of Rochester. 12'

\begin{tabular}{|c|c|c|}
\hline 2 to $3 \mathrm{ft}$. & .45 & 3.50 \\
\hline 3 to $4 \mathrm{ft}$. & .50 & 4.00 \\
\hline 4 to $5 \mathrm{ft}$. & .65 & 5.00 \\
\hline 5 to 6 ft..- & .75 & 5.50 \\
\hline $8 \mathrm{ft}$. heavy_-_. & 1.00 & 6.50 \\
\hline
\end{tabular}

scabra rosea plena. 12'

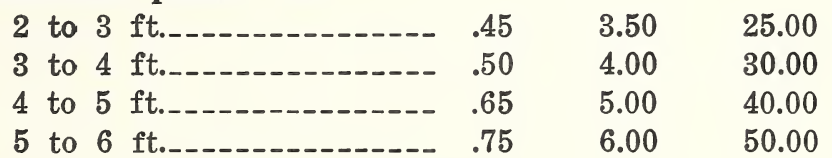

scabra watereri. Waterer's Deutzia. 12'

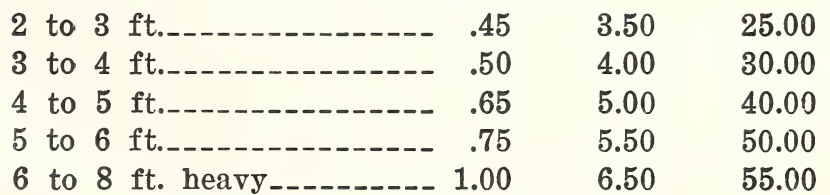

vilmorinae. Vilmorin Deutzia. 10'

3 to 4 ft.-_-_-_- .75

4 to 5 ft._._.

Diervilla sessilifolia. Southern Bush Honeysuckle. 5'

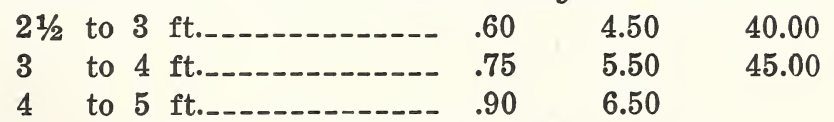

trifida. Dwarf Bush Honeysuckle. ' ${ }^{\prime}$

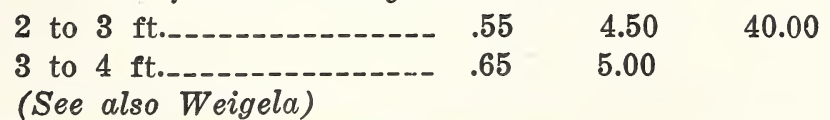

Elaeagnus angustifolia. Russian Olive. 20'

\begin{tabular}{|c|c|c|}
\hline $4 \mathrm{ft}$. & .60 & 5.00 \\
\hline ft._--------- & .75 & 6.50 \\
\hline 6 ft.-_--- & 1.25 & 10.00 \\
\hline to $8 \mathrm{ft.}$ & 1.50 & 12.50 \\
\hline
\end{tabular}




\section{Elaeagnus}

argent

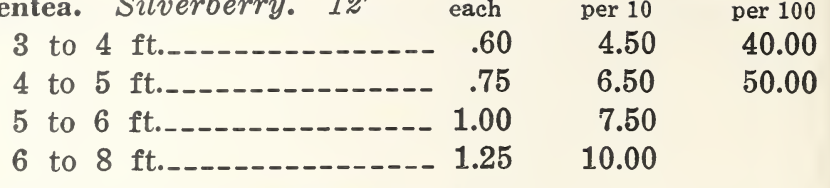

longipes. Cherry Elaeagnus. $6^{\prime}$

$$
\begin{aligned}
& 2 \text { to } 3 \text { ft.--_-_-_-_-_---- } 1.00 \quad 8.50 \\
& 3 \text { to } 4 \text { ft._-_-_-_-_-_-_-_-_ } 1.25 \quad 10.00
\end{aligned}
$$

\begin{tabular}{|c|c|c|}
\hline to $3 \mathrm{ft.} . \ldots$ & .55 & 4.50 \\
\hline to $4 \mathrm{ft}$. & .65 & 5.50 \\
\hline to $5 \mathrm{ft.}$ & .75 & 6.50 \\
\hline to 6 ft...... & 1.25 & 10.00 \\
\hline
\end{tabular}

umbellata. Autumn Elaeagnus. 12'

Elsholtzia stauntoni. $\quad 4^{\prime}$

$$
\begin{aligned}
& 18 \text { to } 24 \text { in.--_-_-_-_-- .50 } 4.00 \\
& 2 \text { to } 3 \mathrm{ft.} .
\end{aligned}
$$

Euonymus alatus. Winged Euonymus. 10'

\begin{tabular}{|c|c|c|}
\hline ft... & .60 & 5.00 \\
\hline to $4 \mathrm{ft.}$ & .70 & 6.00 \\
\hline 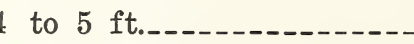 & .75 & 7.00 \\
\hline to $6 \mathrm{ft}$ & 1.00 & 8.50 \\
\hline
\end{tabular}

$$
\begin{aligned}
& 2 \text { to } 3 \text { ft._-_-_-_-_-_-_-_ } 1.60 \quad 12.50 \\
& 3 \text { to } 4 \text { ft._-_-_-_-_-_-_-_ } 2.00 \quad 16.00
\end{aligned}
$$

\begin{tabular}{|c|c|c|}
\hline 2 to $3 \mathrm{ft}$. & .60 & 5.00 \\
\hline 3 to $4 \mathrm{ft.}$ & .70 & 6.00 \\
\hline to $5 \mathrm{ft}$. & .85 & 7.00 \\
\hline 5 to $6 \mathrm{ft}$. & 1.00 & 8.50 \\
\hline 6 to $8 \mathrm{ft}$. & 1.50 & 12.50 \\
\hline
\end{tabular}

americanus. Brook Euonymus. $8^{\prime}$

$$
\begin{aligned}
& 2 \text { to } 3 \text { ft.---_----_----- } .65 \quad 5.00 \quad 40.00 \\
& 3 \text { to } 4 \text { ft._._._. } .75 \quad 6.00 \quad 50.00
\end{aligned}
$$

atropurpureus. Native Wahoo. $15^{\prime}$

bungeanus. Winterberry Euonymus. 15'

europaeus. European Burning Bush. 15'

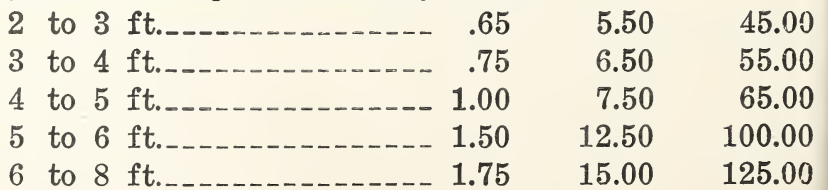




\section{Euonymus}

latifolius. Broadleaf Burning Bush. 10'

$$
\begin{aligned}
& \text { each per } 10 \\
& 3 \text { to } 4 \mathrm{ft.} \\
& 4 \text { to } 5 \mathrm{ft} . \ldots+00
\end{aligned}
$$

maacki. $10^{\prime}$

2 to $3 \mathrm{ft}$.
3 to $4 \mathrm{ft.}$

yedoensis. Yeddo Euonymus. 10'

\begin{tabular}{|c|c|c|}
\hline to $3 \mathrm{ft}$. & .50 & 4.00 \\
\hline 3 to $4 \mathrm{ft}$. & .60 & 5.00 \\
\hline to $5 \mathrm{ft}$. & .75 & 6.50 \\
\hline to $6 \mathrm{ft}$. & 1.25 & 10.00 \\
\hline $6 \mathrm{ft}$. specimens_-_-- & 5.00 & \\
\hline $7 \mathrm{ft}$. specimens___-_- & 7.00 & \\
\hline
\end{tabular}

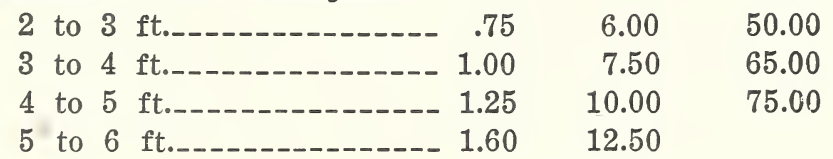

Exochorda grandiflora. Pearl Bush. 10'

Fontanesia fortunei. Fortune Fontanesia. 15'

\begin{tabular}{|c|c|c|}
\hline 2 to $3 \mathrm{ft}$ & .45 & 3.50 \\
\hline 3 to $4 \mathrm{ft}$. & .50 & 4.00 \\
\hline 4 to $5 \mathrm{ft}$ & .65 & 5.00 \\
\hline 5 to $6 \mathrm{ft}$. & .75 & 6.50 \\
\hline to $7 \mathrm{ft}$. & 1.25 & 10.00 \\
\hline
\end{tabular}

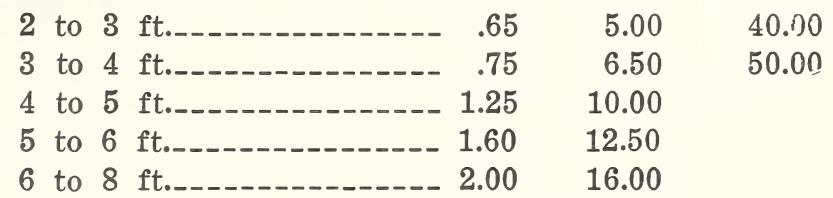

Forsythia intermedia. Border Forsythia. $8^{\prime}$

intermedia spectabilis. Showy Border Forsythia. $8^{\prime}$
2 to $3 \mathrm{ft}$.
.45
3.50
25.00
3 to $4 \mathrm{ft}$.
$4.00 \quad 35.00$
4 to $5 \mathrm{ft.}$
$5.00 \quad 45.00$
5 to $6 \mathrm{ft}$.------------. .75
$6.50 \quad 55.00$

suspensa. Weeping Forsythia.

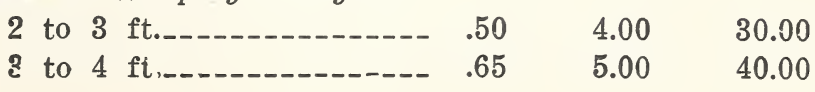


Forsythia

suspensa atrocaulis. Purple stem Forsythia. 6' $^{\prime}$

$$
\begin{array}{rrrr}
2 & \text { each } & \text { per } 10 \\
3 & \text { to } 4 \mathrm{ft.} 4 \mathrm{ft.} . & .75 & 6.00 \\
& &
\end{array}
$$

\begin{tabular}{|c|c|c|}
\hline 2 to $3 \mathrm{ft} . \ldots$ & .45 & 3.00 \\
\hline 3 to $4 \mathrm{ft}$. & .50 & 4.00 \\
\hline 4 to 5 ft. & .65 & 5.00 \\
\hline to $6 \mathrm{ft}$. & .75 & 6.50 \\
\hline
\end{tabular}

suspensa fortunei. Golden Bell. $8^{\prime}$

\begin{tabular}{|c|c|c|}
\hline 2 to $3 \mathrm{ft}$ & .45 & 3.00 \\
\hline 3 to $4 \mathrm{ft}$ & .50 & 4.00 \\
\hline 4 to $5 \mathrm{ft}$. & .65 & 5.00 \\
\hline to $6 \mathrm{ft}$. & .75 & 6.50 \\
\hline
\end{tabular}

suspensa sieboldi. Siebold Forsythia.

\begin{tabular}{|c|c|c|}
\hline 2 to $3 \mathrm{ft}$ & .45 & 3.50 \\
\hline $4 \mathrm{ft}$. & .50 & 4.00 \\
\hline $5 \mathrm{ft}$. & .65 & 5.00 \\
\hline
\end{tabular}

viridissima. Greenstem Forsythia. $8^{\prime}$

Genista tinctoria. Woadwaxen. $3^{\prime}$

$$
\begin{aligned}
& 2 \text { to } 3 \mathrm{ft.} \\
& 3 \text { to } 4 \mathrm{ft.}
\end{aligned}
$$

\begin{tabular}{|c|c|c|}
\hline & .75 & 5.50 \\
\hline & 1.00 & 7.50 \\
\hline & 1.25 & 10.00 \\
\hline & 2.50 & 17.50 \\
\hline & 3.00 & 25.00 \\
\hline
\end{tabular}

Halesia. (See Trees).

Hamamelis virginiana. Witch Hazel. 15'

\begin{tabular}{|c|c|c|c|c|}
\hline to & 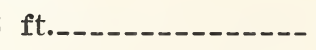 & .50 & 3.50 & 25.00 \\
\hline 3 to & ft._._. & .60 & 4.50 & 35.00 \\
\hline to & ft._- & .75 & 6.50 & 45.00 \\
\hline 6 & 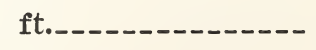 & 1.00 & 7.50 & 60.00 \\
\hline$\varepsilon$ & ft._-_- & 1.25 & 10.00 & 75.00 \\
\hline 10 & ft. heary & 3.25 & 25.00 & \\
\hline
\end{tabular}

japonica. Japanese Witch Hazel. $8^{\prime}$

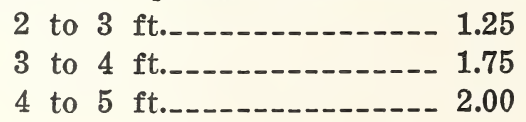

Hibiscus syriacus. Shrub Althea. 12' double varieties. 
Hibiscus-Double Varieties.

Ardens-Purple.

Banner-Blush.

Jeanne d'Arc-White.

Lady Stanley-White, shaded rose.

Rubra Plena-Red.

Speciosa Plena-Pink.

single varieties.

each

per 10

per 100

2 to $3 \mathrm{ft.}$.

4.00

30.00

3 to $4 \mathrm{ft.}$.

5.00

40.00

4 to $5 \mathrm{ft.}$.

6.00

50.00

5 to $6 \mathrm{ft}$.

1.25

10.00

75.00

6 to $8 \mathrm{ft.}$.

Coelestis-Blue.

Rosea-White, crimson eye.

Rubis-Red.

Totus albus-White.

variegatus. Variegated leaved Althea. $8^{\prime}$

2 to $3 \mathrm{ft.} . \ldots$

3 to $4 \mathrm{ft}$.-_-_- $1.25 \quad 10.00$

variegatus meehani. Meehan's Variegated Althea. $6^{\prime}$

2 to 3 ft._._._._._._. $1.00 \quad 7.50$

Hippophae rhamnoides. Sea-buckthorn. 12'

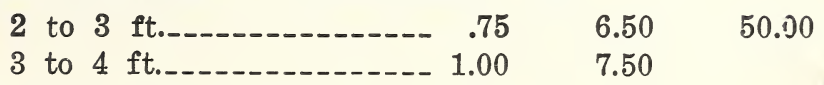

Hovenia dulcis. Raisintree. $6^{\prime}$

$$
\begin{array}{rrr}
18 \text { to } 24 \text { in._-_. } \\
2 \text { to } 3 \text { ft._-_. }
\end{array}
$$

\begin{tabular}{|c|c|c|}
\hline ft._-- & .65 & 5.00 \\
\hline ft....- & .75 & 6.00 \\
\hline 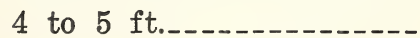 & 1.00 & 7.50 \\
\hline
\end{tabular}

Hydrangea arborescens. Smooth Hydrangea. $6^{\prime}$

arborescens grandiflora. Snowhill Hydrangea. 6'

2 to 3 ft._._._._._._._. $.65 \quad 5.00 \quad 40.00$

3 to 4 ft._-_-_-_-_- $.75 \quad 6.00 \quad 50.00$

cineria sterilis. Ashy Hydrangea. $6^{\prime}$

2 to $3 \mathrm{ft.}$

3 to 4 ft._._._._. $1.00 \quad 7.50 \quad 60.00$

opuloides Otaksa.

4 year -

opuloides Thos. Hogg.

4 year _-_- $1.00 \quad 7.50$ 
Hydrangea.

paniculata. Panicle Hydrangea. 10'

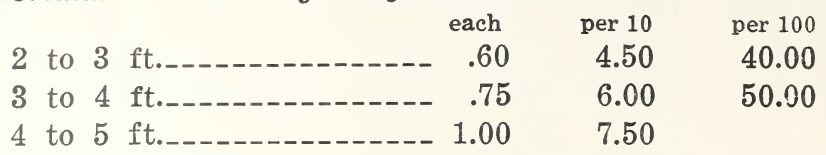

paniculata grandiflora. Peegee Hydrangea. 10'

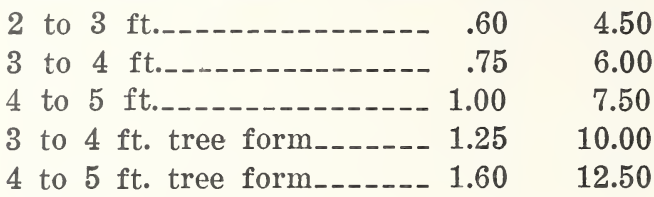

quercifolia. Oakleaf Hydrangea. "4'

2 to 3 ft._._-_-_-_-_-_._- $1.60 \quad 12.50$

radiata. Silverleaf Hydrangea. $6^{\prime}$

2 to 3 ft._-_-_-_-_-_-_- $.60 \quad 5.00$

3 to 4 ft.-_-_-_-_-_-_- $.75 \quad 6.50$

Hypericum aureum. Golden St. Johnswort. 4'

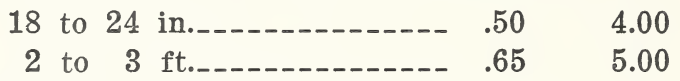

calycinum. (See Perennials).

kalmianum. $4^{\prime}$

18 to 24 in.-_-_-_-_-_- $.50 \quad 4.00$

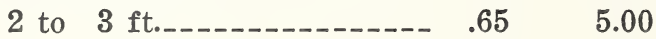

moserianum. Goldflower. $2^{\prime}$

15 to 18 in.-_- 18 to 24 in.-_-

patulum henryi. Henry Hypericum. 4'

18 to 24 in.---_---_----- $.50 \quad 4.00 \quad 30.00$

2 to 3 ft.-_-_-_-_-_- $.65 \quad 5.00 \quad 40.00$

prolificum. Shrubby St. Johnswort. 5'

18 to 24 in.-_-_-_-_-_-_.-. $.50 \quad 4.00$

Ilex monticola. Mountain Winterberry. 10'

2 to 3 ft._-_-_-_-_-_._- $.75 \quad 6.50$

3 to 4 ft._-_-_-_._._._- $1.00 \quad 7.50$

verticillata. Common Winterberry. $6^{\prime}$
2 to $3 \mathrm{ft}$.
.75
6.00
50.00
3 to $4 \mathrm{ft}$
$1.25 \quad 10.00$

Itea virginica. Sweetspire. $\boldsymbol{s}^{\prime}$

2 to $3 \mathrm{ft}$. 
Jasminum nudiflorum. Winter Jasmine. ' $'$

$\begin{array}{rrrr} & \text { each } & \text { per } 10 & \text { per } 100 \\ 18 \text { to } 18 \text { in._. } 24 \text { in._. } & .50 & 4.00 & 30.00 \\ & .75 & 5.00 & 40.00\end{array}$

Kerria japonica. Kerria.

18 to 24 in.
2 to 3 ft.

japonica florepleno. Double Kerria.

2 to 3 ft._._. $1.00 \quad 7.50$

3 to $4 \mathrm{ft.}$

Lespedeza bicolor. Shrub Bushclover. $6^{\prime}$

$\begin{array}{llrl}2 \text { to } 3 \mathrm{ft} . & .60 & 4.50 & 40.00 \\ 3 \text { to } 4 \mathrm{ft} & .75 & 6.50 & 50.00 \\ 4 \text { to } 5 \mathrm{ft} . & \end{array}$

formosa, syn. penduliflorum. Purple Bushclover. 4'
2 year._._. 65
4.50
40.00
3 year.
.75
5.00

formosa albiflora. Japanese Bushclover. $5^{\prime}$

2 year__._. $65 \quad 5.00$

Ligustrum acuminatum. 10'

$\begin{array}{lllll}2 \text { to } 3 \text { ft._. } & & .40 & 2.50 & 20.00 \\ 3 \text { to } 4 \text { ft._. } & .50 & 3.50 & 25.00\end{array}$

acuminatum macrocarpum. Bigberry Privet. 10'

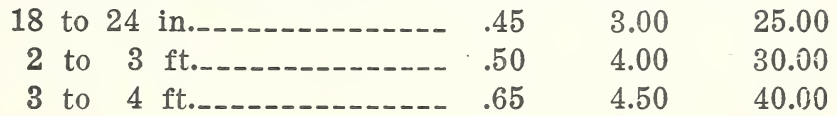

amurense. Amur Privet. 15'

$\begin{array}{rrrr}18 \text { to } 24 \text { in. } & .25 & 2.00 & 15.00 \\ 24 \text { to } 30 \text { in._. } & .35 & 2.50 & 18.00 \\ 2 \text { to } 3 \text { ft. } & .40 & 3.00 & 25.00 \\ 3 \text { to } 4 \text { ft. } & .50 & 4.00 & 30.00 \\ 4 \text { to } 5 \text { ft. } & .65 & 5.00 & 40.00 \\ 5 \text { to } 6 \text { ft. } & \end{array}$

ibolium. Ibolium Privet.

$\begin{array}{rrrrr}18 \text { to } 24 \mathrm{in} & \\ 2 \text { to } 3 \mathrm{ft} . & 30 & 2.50 & 20.00 \\ 3 \text { to } 4 \mathrm{ft} . \ldots & .35 & 3.00 & 25.00\end{array}$

ibota. Ibota Privet. 10'

\begin{tabular}{|c|c|c|}
\hline 2 to $3 \mathrm{ft}$. & .40 & 2.50 \\
\hline 3 to $4 \mathrm{ft}$. & .50 & 3.00 \\
\hline 4 to $5 \mathrm{ft}$. & .60 & 5.00 \\
\hline
\end{tabular}




\section{Ligustrum}

ibota nanum. Pygmy Privet.

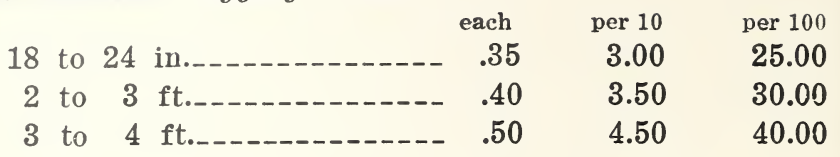

ibota regelianum. Regel Privet.

$\begin{array}{ccccccc}18 & \text { to } 24 & \text { in. } & \text { spread_-_- } & .50 & 4.00 & 30.00 \\ 24 & \text { to } 30 & \text { in. } & \text { spread_--- } & .65 & 4.50 & 35.00 \\ 21 / 2 & \text { to } 3 & \text { ft. } & \text { spread_-_- } & .75 & 6.00 & 45.00 \\ 3 & \text { to } 31 / 2 & \text { ft. } & \text { spread_--- } & 1.00 & 7.50 & 65.00\end{array}$

lodense. Dwarf Privet. 21/2'

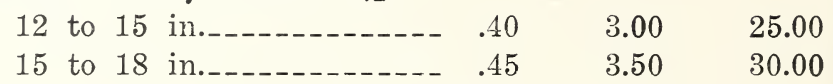

ovalifolium. California Privet. 10'

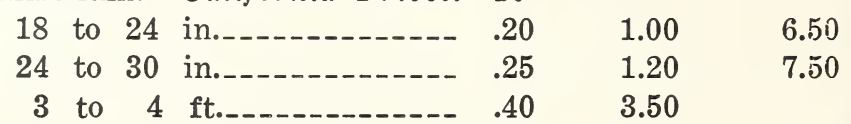

ovalifolium variegatum. Golden Privet. 10'

2 to $3 \mathrm{ft}$.

3 to $4 \mathrm{ft.}$.

vulgare. European Privet. 12'

\begin{tabular}{|c|c|c|}
\hline to $3 \mathrm{ft}$. & .45 & 3.50 \\
\hline to $4 \mathrm{ft}$ & .50 & 4.00 \\
\hline to $5 \mathrm{ft}$. & .60 & 4.50 \\
\hline
\end{tabular}

vulgare foliosum. $10^{\prime}$

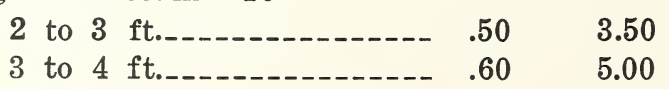

vulgare leucocarpum. Yellowberry Privet.

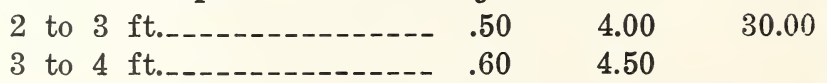

Lindera benzoin. (See Benzoin aestivale).

Lonicera bella albida. White Belle Honeysuckle. 10'

\begin{tabular}{|c|c|c|c|}
\hline to $3 \mathrm{ft} .-$ - & .45 & 3.50 & 25.00 \\
\hline 3 to $4 \mathrm{ft.}$ & .50 & 4.00 & 30.00 \\
\hline 4 to 5 ft. & .65 & 5.00 & 40.00 \\
\hline to $6 \mathrm{ft}$. & .75 & 5.50 & 45.00 \\
\hline to $8 \mathrm{ft}$. & 1.00 & 7.50 & 60.00 \\
\hline
\end{tabular}




\section{Lonicera}

bella rosea. Belle Honeysuckle. 10'

\begin{tabular}{|c|c|c|c|}
\hline & each & per 10 & per 100 \\
\hline 2 to $3 \mathrm{ft}$. & .45 & 3.50 & 25.00 \\
\hline 3 to $4 \mathrm{ft}$. & .50 & 4.00 & 30.00 \\
\hline 4 to $5 \mathrm{ft}$. & .65 & 5.00 & 40.00 \\
\hline
\end{tabular}

billardi. $8^{\prime}$

\begin{tabular}{|c|c|c|}
\hline to $3 \mathrm{ft.}$. & .45 & 3.50 \\
\hline 3 to $4 \mathrm{ft}$. & .50 & 4.00 \\
\hline 4 to 5 ft....- & .60 & 5.00 \\
\hline to $6 \mathrm{ft.}$ & .75 & 6.50 \\
\hline
\end{tabular}

chrysantha. Coralline Honeysuckle. 10'

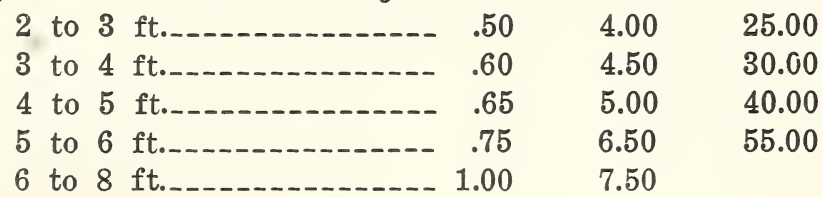

conjugalis. $8^{\prime}$

\begin{tabular}{|c|c|c|c|}
\hline 3 to $4 \mathrm{ft}$. & .50 & 4.50 & 40.00 \\
\hline 4 to $5 \mathrm{ft}$ & .65 & 5.00 & 45.00 \\
\hline 5 to 6 ft.... & .75 & 6.50 & 55.0 \\
\hline 6 to $8 \mathrm{ft}$ & 1.00 & 8.50 & 70.0 \\
\hline
\end{tabular}

fragrantissima. Winter Honeysuckle. $8^{\prime}$

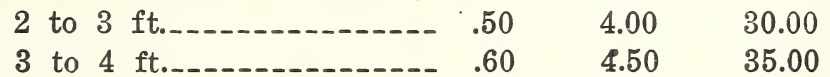

gracilipes. Spangled Honeysuckle. $6^{\prime}$

\begin{tabular}{|c|c|c|}
\hline to $3 \mathrm{ft}$. & .50 & 3.50 \\
\hline to $4 \mathrm{ft}$ & .60 & 4.50 \\
\hline to $5 \mathrm{ft}$ & .65 & 5.00 \\
\hline to $6 \mathrm{ft}$. & .80 & 7.00 \\
\hline
\end{tabular}

kesselringi. Black fruited Honeysuckle. 10'

3 to 4 ft._._-_._-_._-_.-. $.60 \quad 4.50$

35.00

4 to 5 ft._._._._._._._. $.65 \quad 5.00$

5 to 6 ft._-_-_-_-_-_-_-- $.75 \quad 6.50$

korolkowi floribunda.

Broad Blueleaf Honeysuckle. 10'

2 to $3 \mathrm{ft.} . \ldots$.

$5.00 \quad 45.00$

3 to 4 ft._._._-_._._._. $.75 \quad 6.50$

ledebouri.

\begin{tabular}{|c|c|c|}
\hline to $3 \mathrm{ft}$. & .40 & 3.50 \\
\hline 3 to $4 \mathrm{ft}$. & .50 & 4.00 \\
\hline 4 to $5 \mathrm{ft}$. & .65 & 5.00 \\
\hline
\end{tabular}




\section{Lonicera}

maacki. Amur Honeysuckle. 10'

\begin{tabular}{|c|c|c|c|}
\hline & each & per 10 & per 100 \\
\hline to $4 \mathrm{ft}$. & .60 & 4.50 & 35.00 \\
\hline to $5 \mathrm{ft}$. & .75 & 5.50 & 45.00 \\
\hline to $6 \mathrm{ft}$. & 1.00 & 7.50 & 60.00 \\
\hline to $7 \mathrm{ft.}$. & 1.25 & 10.00 & \\
\hline
\end{tabular}

morrowi. Japanese Bush Honeysuckle. $8^{\prime}$

\begin{tabular}{|c|c|c|}
\hline to $3 \mathrm{ft}$. & .45 & 3.50 \\
\hline 3 to $4 \mathrm{ft}$. & .50 & 4.00 \\
\hline to $5 \mathrm{ft}$. & .65 & 5.00 \\
\hline to $6 \mathrm{ft.}$ & .75 & 6.50 \\
\hline
\end{tabular}

morrowi. (Yellow Fruited). $8^{\prime}$

\begin{tabular}{|c|c|c|}
\hline to $3 \mathrm{ft}$. & .45 & 3.50 \\
\hline to $4 \mathrm{ft.}$ & .50 & 4.00 \\
\hline to $5 \mathrm{ft}$. & .65 & 5.00 \\
\hline to $6 \mathrm{ft}$. & .75 & 6.50 \\
\hline
\end{tabular}

muendeniensis. Muenden Honeysuckle. $8^{\prime}$

\begin{tabular}{|c|c|c|c|}
\hline 2 to 3 ft.-- & .45 & 3.50 & 25.00 \\
\hline 3 to $4 \mathrm{ft}$. & .50 & 4.00 & 30.00 \\
\hline 4 to $5 \mathrm{ft}$. & .65 & 5.50 & 45.0 \\
\hline 5 to 6 ft.. & .75 & 6.00 & 50.00 \\
\hline to $8 \mathrm{ft.}$ & 1.00 & 7.50 & 60.0 \\
\hline
\end{tabular}

pileata. Privet Honeysuckle. $2^{\prime}$

6 to 12 in.-_-_- $\quad .50 \quad 4.00 \quad 35.00$

quinquelocularis. Mistletoe Honeysuckle. 10'

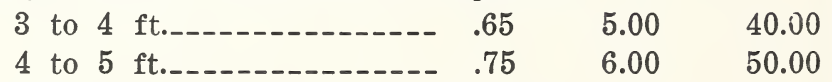

ruprechtiana. Manchurian Honeysuckle. 10'

\begin{tabular}{|c|c|c|}
\hline ft.- & .45 & 3.50 \\
\hline to $4 \mathrm{ft}$. & .50 & 4.00 \\
\hline to $5 \mathrm{ft}$. & .65 & 5.00 \\
\hline to $6 \mathrm{ft}$. & .75 & 6.00 \\
\hline
\end{tabular}

spinosa alberti. Thorn Honeysuckle. 2'

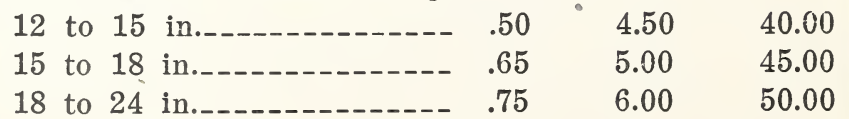

standishi. $5^{\prime}$

3 to 4 ft._-_-_-_-_- $.65 \quad 5.00$

syringantha. Lilac Honeysuckle.

18 to 24 in.-_-_-_- 6.00 


\section{Lonicera}

tatarica. Red Tatarian Honeysuckle. 10'

\begin{tabular}{|c|c|c|c|}
\hline & each & per 10 & per 100 \\
\hline 2 to $3 \mathrm{ft}$. & .45 & 3.00 & 25.00 \\
\hline 3 to $4 \mathrm{ft}$. & .50 & 4.00 & 30.00 \\
\hline 4 to $5 \mathrm{ft}$. & .65 & 5.00 & 45.00 \\
\hline 5 to $6 \mathrm{ft} . .--$ & .75 & 6.00 & 50.00 \\
\hline 6 to $7 \mathrm{ft}$. & 1.25 & 9.00 & 75.0 \\
\hline
\end{tabular}

tatarica alba. White Tatarian Honeysuckle. 10'

\begin{tabular}{|c|c|c|}
\hline 2 to $3 \mathrm{ft}$. & .45 & 3.50 \\
\hline 3 to $4 \mathrm{ft}$. & .50 & 4.00 \\
\hline 4 to $5 \mathrm{ft}$ & .65 & 5.00 \\
\hline 5 to $6 \mathrm{ft}$. & .75 & 6.00 \\
\hline to $8 \mathrm{ft}$. & 1.25 & 9.00 \\
\hline
\end{tabular}

tatarica grandiflora. Pink Tatarian Honeysuckle. 10'

\begin{tabular}{|c|c|c|}
\hline 2 to $3 \mathrm{ft.}$ & .45 & 3.50 \\
\hline 3 to $4 \mathrm{ft.}$ & .50 & 4.00 \\
\hline 4 to $5 \mathrm{ft}$ & .65 & 5.00 \\
\hline 6 ft...-. & .75 & 6.00 \\
\hline to $7 \mathrm{ft.}$. & 1.25 & 9.00 \\
\hline
\end{tabular}

translucens. White-fruited Honeysuckle. 10'

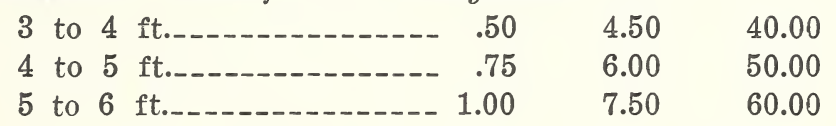

virginalis alba. Maiden Honeysuckle. 10'

\begin{tabular}{|c|c|c|}
\hline to $3 \mathrm{ft.} .-$ & .45 & 3.00 \\
\hline 3 to 4 ft.. & .50 & 4.00 \\
\hline 4 to $5 \mathrm{ft.}$ & .65 & 5.00 \\
\hline
\end{tabular}

xylosteum. Fly Honeysuckle. $8^{\prime}$

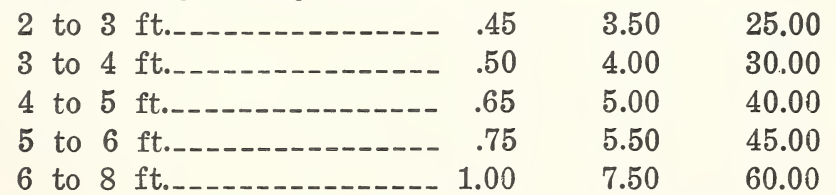

Lycium chinense. Chinese Matrimony Vine. $5^{\prime}$

\begin{tabular}{|c|c|c|}
\hline ft._. & .35 & 2.50 \\
\hline to $4 \mathrm{ft}$. & .45 & 3.00 \\
\hline 4 to $5 \mathrm{ft}$. & .50 & 4.00 \\
\hline
\end{tabular}

halimifolium. Common Matrimony Vine.

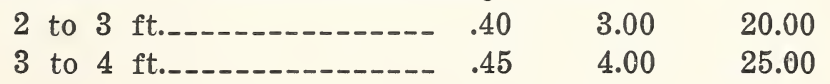


Myrica cerifera. Southern Waxmyrtle. 5'

\begin{tabular}{|c|c|c|c|}
\hline & each & per 10 & per 100 \\
\hline to 24 in. & .75 & 6.00 & 55.00 \\
\hline to 30 in.-.-.- & 1.00 & 7.50 & 60.00 \\
\hline $2 \frac{1}{2}$ to $3 \mathrm{ft}$. & 1.25 & 10.00 & \\
\hline Sweetgale. 4' & & & \\
\hline 18 to 24 in. & .65 & 5.50 & 50.60 \\
\hline 2 to $3 \mathrm{ft}$. & .75 & 7.00 & 60.00 \\
\hline
\end{tabular}

Neillia sinensis. Tube Neillia. 4'

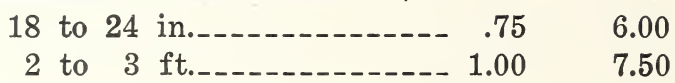

Oxydendrum arboreum. Sourwood. 40'

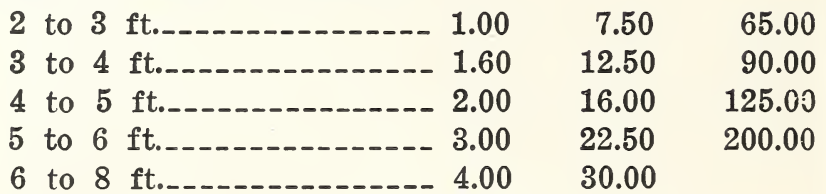

Philadelphus coronarius. Sweet Mockorange. 10'

\begin{tabular}{|c|c|c|}
\hline 2 to $3 \mathrm{ft}$. & .45 & 3.50 \\
\hline 3 to $4 \mathrm{ft}$. & .50 & 4.00 \\
\hline 4 to $5 \mathrm{ft}$. & .65 & 5.00 \\
\hline $6 \mathrm{ft.}$ & .75 & 5.50 \\
\hline 6 to $8 \mathrm{ft}$. & 1.00 & 6.50 \\
\hline
\end{tabular}

coronarius aureus. Golden Mockorange. 4'

18 to 24 in._-_._._. $\quad .75 \quad 6.50 \quad 50.00$

coronarius multiflorus plenus. $6^{\prime}$

2 to $3 \mathrm{ft.} .-[-\ldots$

coronarius speciosissimus. Roundleaf Mockorange. 10'

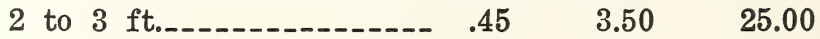

3 to 4 ft._-_-_-_-_-_-_- $.50 \quad 4.00 \quad 30.00$

4 to $5 \mathrm{ft.}$.

dianthiflorus plenus. 4'

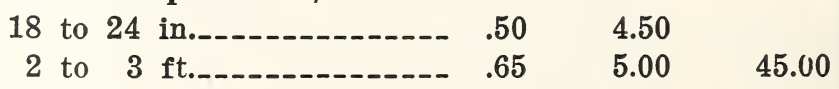

falconeri. Star Mockorange. $8^{\prime}$

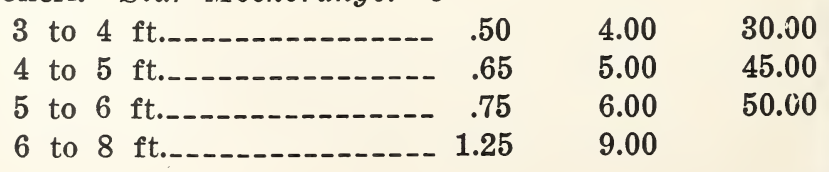




\section{Philadelphus}

gordonianus. Gordon Mockorange. 12'

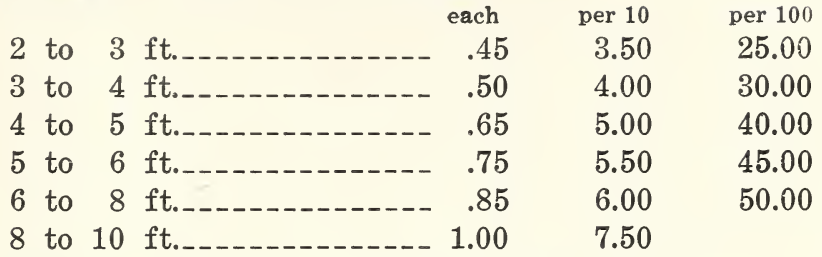

grandiflorus. Big Scentless Mockorange. $8^{\prime}$

2 to $3 \mathrm{ft.}$.

25.00

3 to $4 \mathrm{ft.}$.......... .50

4.00

30.00

4 to $5 \mathrm{ft.}$

5.00

40.00

5 to $6 \mathrm{ft.}$

5.50

45.00

6 to $8 \mathrm{ft.}$

6.00

50.00

8 to $10 \mathrm{ft.}$ t._-_-_-_-_._- 1.00

7.50

lemoinei Avalanche. 5'

2 to $3 \mathrm{ft.}$.

4.50

40.00

3 to 4 ft._._._._._._.

5.50

50.00

lemoinei Bouquet Blanc. $5^{\prime}$

2 to $3 \mathrm{ft.} .---.-05$

5.00

lemoinei erectus. $5^{\prime}$

2 to $3 \mathrm{ft.}$

4.50

40.00

3 to $4 \mathrm{ft.}$

5.50

50.00

lewisi. Lewis Mockorange. 10'

2 to 3 ft._-_-_-_-_._- .45

3.00

22.00

3 to $4 \mathrm{ft.}$

4.00

30.00

4 to $5 \mathrm{ft}$.

5.00

40.00

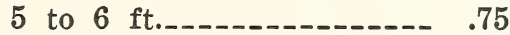

5.50

45.00

6 to $8 \mathrm{ft}$.

6.50

nepalensis. Nepal Mockorange. 10'

3 to $4 \mathrm{ft.}$

4.00

30.00

4 to 5 ft._-_-_-

5.00

40.00

5 to $6 \mathrm{ft}$.

5.50

45.00

6 to $8 \mathrm{ft}$.

1.00

6.50

50.00

nivalis. Snowbank Mockorange. $10^{\prime}$

2 to $3 \mathrm{ft.}$

$3.00 \quad 25.00$

3 to $4 \mathrm{ft}$._-_-_.-.

4 to $5 \mathrm{ft}$.

4.00

30.00

5 to $6 \mathrm{ft.}$.

5.00

40.00

6 to $8 \mathrm{ft.}$

5.50

45.00

6.50

50.00

Pavillon Blanc. $8^{\prime}$

2 to $3 \mathrm{ft}$. 


\section{Philadelphus}

zeyheri. Zeyher Mockorange. 10'

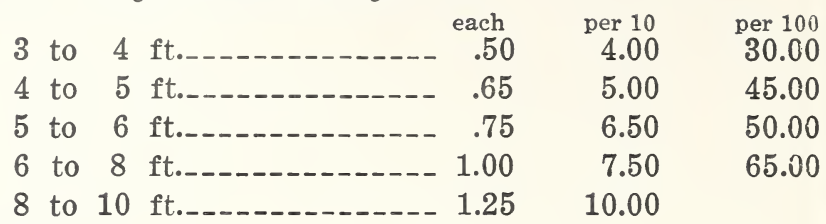
virginal. $8^{\prime}$

$$
\begin{aligned}
& 2 \text { to } 3 \text { ft._-_-_._-_-_- } 1.00 \quad 7.50 \\
& 3 \text { to } 4 \mathrm{ft} .
\end{aligned}
$$

Photinia villosa. $8^{\prime}$

$$
\begin{aligned}
& 4 \text { to } 5 \text { ft._._._-_._-_._- } 1.25 \quad 10.00 \\
& 5 \text { to } 6 \mathrm{ft} \text {._-_.- } 1.50 \quad 12.50
\end{aligned}
$$

Physocarpus opulifolius. Ninebark. 10'

2 to 3 ft._................... .45

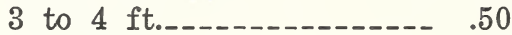

$3.50 \quad 30.00$

4 to 5 ft.................. .60

$5.00 \quad 40.00$

5 to $6 \mathrm{ft.}$

$5.50 \quad 45.00$

6 to 8 ft._._.............

\begin{tabular}{|c|c|c|c|}
\hline 2 to $3 \mathrm{ft}$. & .45 & 3.00 & 22.00 \\
\hline 3 to $4 \mathrm{ft}$. & .50 & 3.50 & 30.00 \\
\hline 4 to $5 \mathrm{ft}$ & .60 & 5.00 & 40.00 \\
\hline to $6 \mathrm{ft}$. & .75 & 5.50 & 45.0 \\
\hline t. & .85 & 6.50 & 55.0 \\
\hline
\end{tabular}

$6.50 \quad 55.00$

6 to $8 \mathrm{ft}$. specimens__-__- 3.50

opulifolius aureus. Goldleaf Ninebark. 10'

\begin{tabular}{|c|c|c|}
\hline 5 ft._-n & .60 & 5.00 \\
\hline $6 \mathrm{ft}$. & .75 & 6.00 \\
\hline $8 \mathrm{ft.}$. & 1.00 & 7.50 \\
\hline to $10 \mathrm{ft.}$ & 1.25 & 10.00 \\
\hline
\end{tabular}

Potentilla fruticosa. Shrubby Cinquefoil. 4'

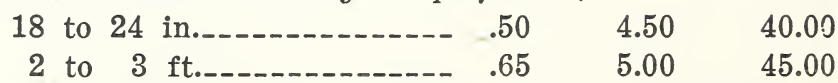

Prunus americana. American Plum. 20'

americana Newport. Purple-leaved American Plum. 20'

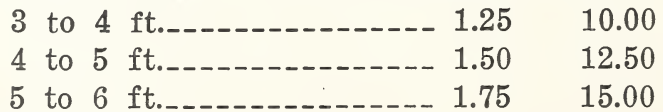

besseyi. Bessey Cherry. $8^{\prime}$

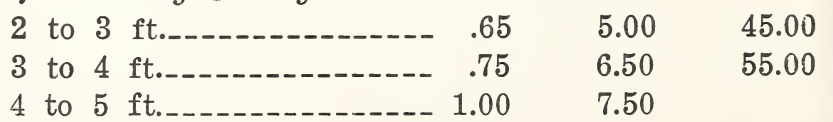




\section{Prunus}

cerasifera pissardi. Purpleleaf Plum. 12'

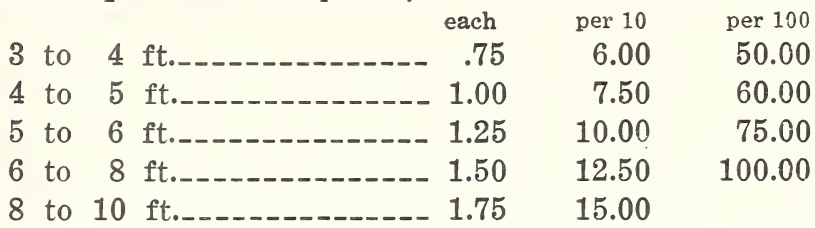

glandulosa. Flowering Almond. 10'

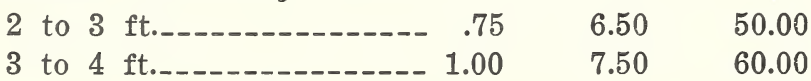
glandulosa sinensis. Double Pinkflowering Almond. $6^{\prime}$

\begin{tabular}{|c|c|c|}
\hline 2 to 3 ft. & .60 & 5.00 \\
\hline 3 to $4 \mathrm{ft}$ & .75 & 6.00 \\
\hline 4 to $5 \mathrm{ft}$ & 1.25 & 10.00 \\
\hline 2 to $3 \mathrm{ft}$ own roots & 1.50 & 12.50 \\
\hline 3 to $4 \mathrm{ft}$. own roots & 2.00 & 15.00 \\
\hline
\end{tabular}
glandulosa albiplena.

Double Whiteflowering Almond. $6^{\prime}$

2 to $3 \mathrm{ft} . \ldots$.

3 to $4 \mathrm{ft}$.

$5.00 \quad 40.60$

4 to 5 ft._._.

$6.00 \quad 50.00$

2 to $3 \mathrm{ft}$. own roots_____- $1.50 \quad 12.50$

maacki. Amur Cherry. 12'

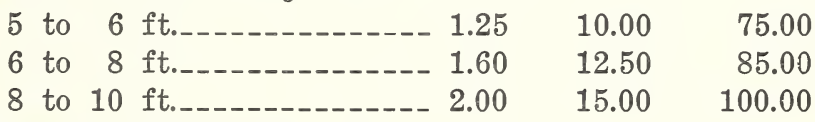

maritima. Beech Plum. 12'

$\begin{array}{llrll}2 \text { to } 3 \mathrm{ft} . & \\ 3 \text { to } 4 \mathrm{ft} . & .65 & 5.50 & 50.00 \\ 4 \text { to } 5 \mathrm{ft.} & .75 & 6.50 & 55.00\end{array}$

pennsylvanica. Pin Cherry. 25'

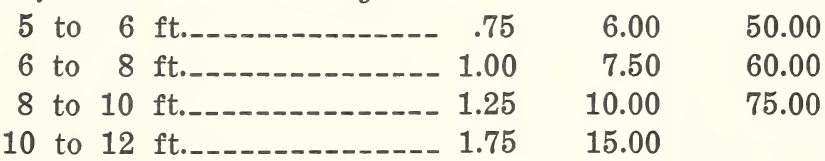

spinosa. Blackthorn. 12'

$\begin{array}{llll}4 \text { to } 5 \mathrm{ft} . & \\ 6 \text { to } 8 \mathrm{ft} . & \end{array}$

tomentosa. Nanking Cherry. $8^{\prime}$

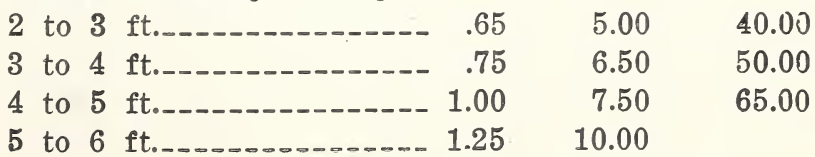




\section{Prunus}

triloba. Doubleflowering Plum. 10'

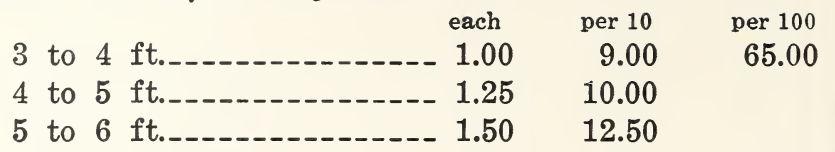

virginiana. Chokecherry. $30^{\prime}$

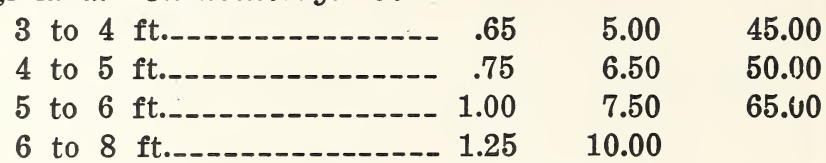

Pyrus arbutifolia. (See Aronia).

Rhamnus caroliniana. Carolina Buckthorn. 25'

2 to $3 \mathrm{ft.}$

$3.00 \quad 25.00$

3 to $4 \mathrm{ft.}$.

$4.00 \quad 30.00$

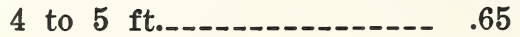

$5.00 \quad 45.00$

cathartica. Buckthorn. 12'

3 to 4 ft.-_-_-_-_-_-_-- .45

$3.00 \quad 25.00$

4 to $5 \mathrm{ft.}$.......

4.50

dahurica. Dahurian Buckthorn. 12'

2 to $3 \mathrm{ft.}$

3 to $4 \mathrm{ft}$.

4 to $5 \mathrm{ft}$.

5 to $6 \mathrm{ft.}$

6 to $8 \mathrm{ft}$.

frangula. Glossy Buckthorn. 12'

3 to $4 \mathrm{ft.}$

4 to $5 \mathrm{ft.}$

5 to $6 \mathrm{ft}$...-.

6 to $8 \mathrm{ft.}$

$2.50 \quad 20.00$

$3.50 \quad 25.00$

$4.50 \quad 30.00$

$5.00 \quad 40.00$

$6.50 \quad 50.00$

purshiana. Cascara Buckthorn. 12'

3 to $4 \mathrm{ft.}$._-_-_._- .45

4 to $5 \mathrm{ft}$.............

5 to $6 \mathrm{ft.}$

6 to $8 \mathrm{ft.}$

$3.50 \quad 25.00$

$4.50 \quad 30.00$

$5.00 \quad 40.00$

$6.50 \quad 50.00$

$3.50 \quad 25.00$

$4.00 \quad 30.00$

$5.00 \quad 40.00$

$6.50 \quad 50.00$

Rhodotypos kerrioides. Jetbead. $6^{\prime}$

2 to $3 \mathrm{ft.}$

$4.50 \quad 35.00$

3 to 4 ft._._._-_._- .75

$5.50 \quad 45.00$

4 to $5 \mathrm{ft.}$

$7.50 \quad 60.00$

Rhus canadensis. Fragrant Sumac. $\sigma^{\prime}$

2 to 3 ft................

3 to $4 \mathrm{ft}$. 


\section{Rhus}

copallina. Shining Sumac. 20'

$\begin{array}{rrrrr}2 & \text { each } & \text { per } 10 & \text { per } 100 \\ 3 \text { to } 3 \text { ft._. } 4 \text { ft._. } & .60 & 5.00 & 40.00 \\ 4 \text { to } 5 \text { ft._. } & .75 & 6.00 & 50.00\end{array}$

cotinus. Purple Fringe or Smoketree. 12'

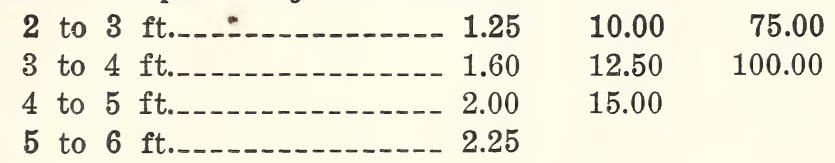

glabra. Smooth Sumac. 12'

2 to 3 ft._.
3 to 4 ft._.

glabra laciniata. Cutleaf Sumac. $5^{\prime}$

2 to 3 ft................ .75

3 to 4 ft._. $1.00 \quad 7.50$

javanica. Java Sumac. 18'

3 to 4 ft._. $1.00 \quad 7.50$

4 to $5 \mathrm{ft.}$....... $1.25 \quad 10.00$

typhina. Staghorn Sumac. 25'

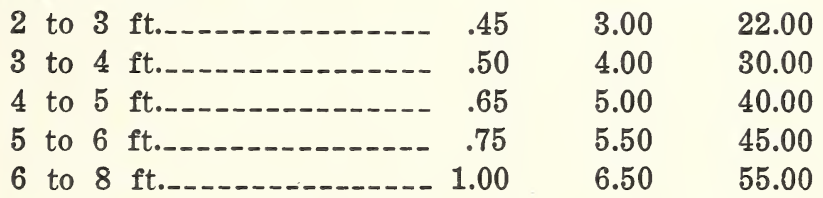

typhina laciniata. Shredded Sumac. 25'

2 to $3 \mathrm{ft.}$
3 to $4 \mathrm{ft.}$
4 to $5 \mathrm{ft.}$
5 to $6 \mathrm{ft.}$

Ribes aureum. Slender Golden Currant. 10'

2 to 3 ft._.
3 to 4 ft._.
4 to 5 ft._.
5 to 6 ft._.

alpinum. Mountain Currant. $4^{\prime}$

$\begin{array}{rrrrr}18 \text { to } 24 \text { in. } & \\ 2 \text { to } 3 \text { ft. } & .65 & 5.50 & 50.00 \\ 3 \text { to } 4 \text { ft._. } & .75 & 7.00 & 65.00\end{array}$

fasciculatum. Winterberry Currant.

18 to 24 in...... $65 \quad 5.00$

2 to 3 ft._. $\quad .75 \quad 6.50 \quad 55.00$ 
Ribes

gordonianum. Gordon Currant. 8'

\begin{tabular}{|c|c|c|c|}
\hline & each & per 10 & per 100 \\
\hline 3 to $4 \mathrm{ft}$. & .60 & 4.50 & 40.00 \\
\hline 4 to $5 \mathrm{ft.}$ & .65 & 6.00 & 50.00 \\
\hline 5 to $6 \mathrm{ft}$. & .85 & 7.00 & 60.00 \\
\hline
\end{tabular}

sanguineum. Ruby Winter Currant.

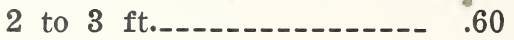

3 to 4 ft._-_-_-_-_-_- $.65 \quad 5.00$

Robinia viscosa. Clammy Locust. 10'

2 to $3 \mathrm{ft.}$

$6.50 \quad 50.00$

3 to 4 ft._-_-_-_-_-_-_-_-- 1.00

$7.50 \quad 65.00$

Rosa acicularis. Prickly Rose. 5'

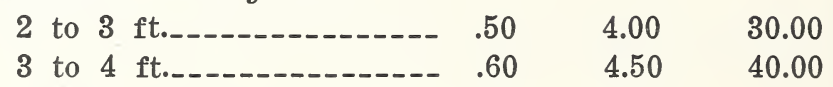

blanda. Meadow Rose. 5'

18 to 24 in..-_-_-_._- .50

2 to 3 ft._-_-_-_-_-_- .60

$4.00 \quad 30.00$

3 to 4 ft._._-_-_-_-_-_-_.- .65

$4.50 \quad 40.00$

$5.00 \quad 45.00$

canina. Dogbrier. $8^{\prime}$

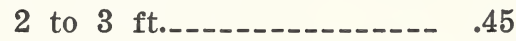

$4.00 \quad 30.00$

3 to $4 \mathrm{ft}$.

$4.50 \quad 40.00$

foetida. Austrian Copper Rose.

2 to $3 \mathrm{ft.}$.

helenae. Helen Rose.

2 year -_-_-_-_- 1.00

hugonis. Hugonis Rose. $6^{\prime}$

2 to $3 \mathrm{ft.}$.-_-_-_-_-_.-1.60 $14.00 \quad 125.00$

humilis. Pasture Rose. 5'

18 to 24 in.-_-

$4.00 \quad 30.00$

2 to 3 ft._-_-_-_-_-_-- $.55 \quad 4.50 \quad 40.00$

3 to 4 ft.-_-_-_-_-_- $.60 \quad 5.00 \quad 45.00$

lucida. Virginia Rose. $6^{\prime}$

18 to 24 in.-_-_-

$4.00 \quad 30.00$

2 to 3 ft._-_-_-_-_-_-_. $.55 \quad 4.50 \quad 40.00$

3 to 4 ft._-_-_-_-_- $.60 \quad 5.00 \quad 45.00$

multiflora. Japanese Rose.

\begin{tabular}{|c|c|c|}
\hline t. & .50 & 3.50 \\
\hline to $4 \mathrm{ft.}$ & .55 & 4.00 \\
\hline 5 ft. & .65 & 5.00 \\
\hline
\end{tabular}




\section{Rosa}

nitida. Bristly Rose. '3' each per 10 per 100

\begin{tabular}{|c|c|c|}
\hline & 24 in. & .50 \\
\hline & 3 ft. & .60 \\
\hline 3 & $4 \mathrm{ft} .--$ & .65 \\
\hline
\end{tabular}

palustris. Swamp Rose. $8^{\prime}$

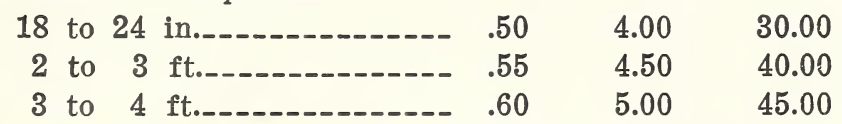

rubiginosa. Sweetbrier. $6^{\prime}$

\begin{tabular}{|c|c|c|}
\hline 2 to $3 \mathrm{ft.} .--$ & .50 & 4.00 \\
\hline to $4 \mathrm{ft}$. & .60 & 4.50 \\
\hline 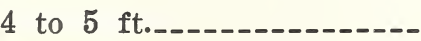 & .65 & 5.00 \\
\hline
\end{tabular}

rubiginosa hybrids. Lady Penzance, Lord Penzance, Green Mantle, Lucy Ashton, Jeannie Deans, and Flora McIvor. $6^{\prime}$

2 to 3 ft.-_-_-_-_-_--- $1.00 \quad 7.50$ rubrifolia. Redleaf Rose. $6^{\prime}$

\begin{tabular}{|c|c|c|}
\hline 2 to $3 \mathrm{ft}$. & .65 & 5.00 \\
\hline 3 to $4 \mathrm{ft}$. & .75 & 6.50 \\
\hline 4 to $5 \mathrm{ft}$ & 1.00 & 7.50 \\
\hline
\end{tabular}

rugosa. Rugosa Rose. $6^{\prime}$

\begin{tabular}{|c|c|c|}
\hline 24 in. & .45 & 3.00 \\
\hline $3 \mathrm{ft} .--$ & .50 & 4.00 \\
\hline 4 ft._------------ & .60 & 4.50 \\
\hline
\end{tabular}

rugosa alba. White Rugosa Rose. $6^{\prime}$

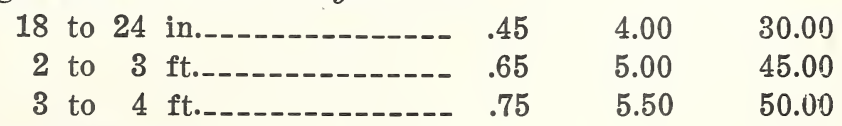
rugosa hybrids.
2 to $3 \mathrm{ft}$.
1.00
7.50
3 to 4 ft.-_-_-_-_-_-_ $1.10 \quad 10.00$

Varieties:-Blanche de Coubert, C. F. Meyer C. F. Worth, Agnes Carmen, New Century, Nova Zembla, Mad. Geo. Bruant, Mrs. Anthony Waterer, Belle Poitevine, Sir Thomas Lipton. sericea. 4'

2 to 3 ft._._._-_._-_._- 1.00

setigera. Prairie Rose. $6^{\prime}$

\begin{tabular}{|c|c|c|}
\hline ft...- & .45 & 3.00 \\
\hline to $4 \mathrm{ft}$. & .50 & 4.00 \\
\hline to $5 \mathrm{ft.}$ & .60 & 4.50 \\
\hline
\end{tabular}


Rosa

spinosissima altaica. Altai Rose. 4'

\begin{tabular}{|c|c|c|c|}
\hline & each & per 10 & per 100 \\
\hline 18 to 24 in. & .60 & 5.00 & 40.00 \\
\hline 2 to $3 \mathrm{ft}_{0}$ & .75 & 6.00 & 50.00 \\
\hline
\end{tabular}

wichuraiana. Wichurian Rose. '2'

2 year -..-_-_._- .50

$4.00 \quad 30.00$

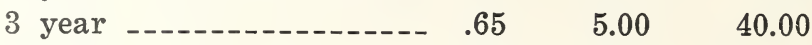

4 year -_-

wichuraiana hybrids.

2 year -

Jersey Beauty, Sweetheart, Universal Favorite, Manda's Triumph, South Orange Perfection.

\section{Roses}

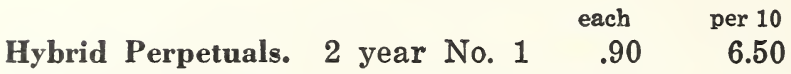

Alfred Colomb

Anne de Diesbach

Baroness Rothschild

Baron de Bonstettin

Clio

Coq. des Alps

Earl of Dufferin

Eugene Furst

Francois Levet

Gen. Jacqueminot

John Hopper
J. B. Clark

Mrs. John Laing

M. P. Wilder

Magna Charta

Marg. de St. Amande

Margaret Dickson

Paul Neyron

Prince Camille de Rohan

Tom Wood

Ulrich Brunner

Hybrid Teas. 2 year No.

British Queen

Chateau de Clos Vougeot

Etoile de France

Harry Kirk

Jonkheer J. L. Mock

Killarney

Lady Hillingdon

Mrs. McKean
1.10

9.00

Mad. Abel Chatenay

Mad. Caroline Testout

Marquise De Sinety

Mrs. A. R. Waddel!

Ophelia

Pharisaer

Sunburst

White Killarney

American Beauty

Frau Karl Druschki

Gloire de Chedane-Guinoisseau

Gruss an Teplitz 
Climbing roses.

each per 10

per 100

American Beauty (climbing) - .75

6.00

American Pillar _._._._._. .75

6.00

Baltimore Belle _._._._. . .65

5.00

Dr. W. Van Fleet__._._. 1.00

7.50

Dorothy Perkins, 2 year_--- .65

5.50

45.00

Dorothy Perkins, 3 year___-- .75

6.00

50.00

Excelsa

6.00

Gardenia _._. 1.00

7.50

Hiawatha _._._-_._._. . . 75

6.00

50.00

Paul's Scarlet Climber__._-_ 1.00

7.50

Prairie Queen _._._._._. .65

5.00

Silver Moon _._-_._-_-_ 1.00

7.50

White Dorothy Perkins _---- .75

6.00

65.00

50.00

\section{Ramblers :}

Blue _... . 75

6.50

Crimson _.

6.50

White _._. 75

6.50

Yellow

Baby Rambler

Erna Teschendorf _._._. $.90 \quad 7.00$

Ellen Poulsen _._._. $.90 \quad 7.00$

Persian Yellow _- $1.00 \quad 7.50$

Rubus deliciosus. Boulder Raspberry. 5'

2 to $3 \mathrm{ft.}$.

odoratus. Flowering Raspberry. $6^{\prime}$

2 to $3 \mathrm{ft.} . \ldots .55$

3 to 4 ft._._. 60

4 to $5 \mathrm{ft.} . \ldots 5$

pheonicolasius. Wineberry. $8^{\prime}$

2 to $3 \mathrm{ft.} . \ldots . . .75$

3 to $4 \mathrm{ft}$.

Salix incana. syn. rosmarinifolia.

Rosemary Willow. 20'

2 to 3 ft. shrub form____ .45

3.00

25.00

3 to $4 \mathrm{ft}$. shrub form__- .55

4.00

30.00

4 to $5 \mathrm{ft}$. shrub form___- .65

5.00

40.00

5 to $6 \mathrm{ft}$. shrub form____ .75

6 to $8 \mathrm{ft}$. shrub form__._ 1.25 
Salix

irrorata. Bluestem Willow. 12'

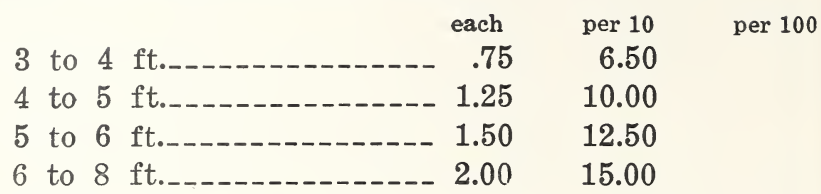

mutabilis. $5^{\prime}$

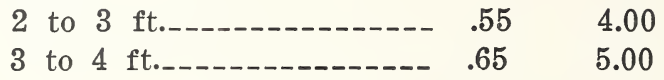

vitellina glauca._-_Blue Russian Willow. 20'

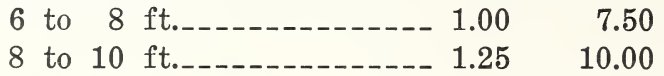

Sambucus canadensis. American Elder. 10'

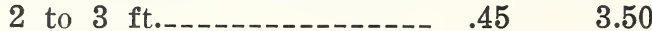

25.00

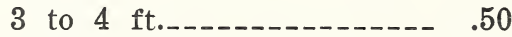

4.00 30.00

4 to 5 .65

5.00 40.00

5 to 6

6.00 50.00

6 to 8

.75

7.50

canadensis acutiloba. Cutleaved Elder. 10'

\begin{tabular}{|c|c|}
\hline to $3 \mathrm{ft}$. & .45 \\
\hline 3 to 4 ft... & .50 \\
\hline 4 to 5 ft. & .65 \\
\hline to $6 \mathrm{ft}$. & .75 \\
\hline opean Elder. 15' & \\
\hline ft.---1-- & .55 \\
\hline 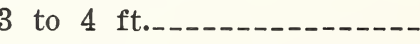 & .65 \\
\hline 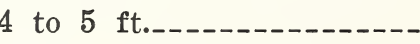 & .75 \\
\hline
\end{tabular}

nigra aurea. Golden European Elder. 15'

\begin{tabular}{|c|c|c|}
\hline 3 ft.-. & .55 & 4.00 \\
\hline to $4 \mathrm{ft.}$ & .65 & 5.00 \\
\hline ft. - & .75 & 6.50 \\
\hline to $6 \mathrm{ft.}$ & 1.00 & 7.50 \\
\hline
\end{tabular}

nigra variegata. Variegated Elder. 10'

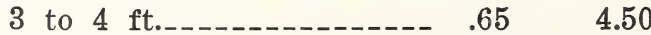

4 to 5 ft._-_-_-_-_- $.75 \quad 5.50$

racemosa. European Red Elder. 8'

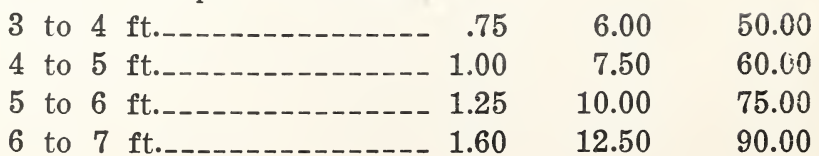


Shepherdia argentea. Silver Buffaloberry. 15'

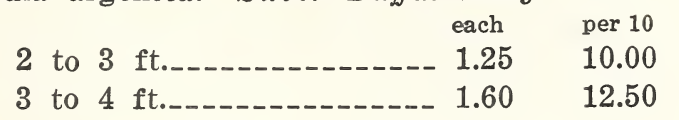

Sophora japonica. Chinese Scholartree. 25'

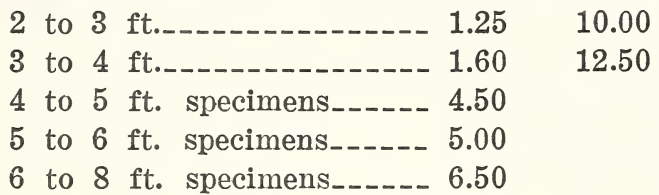

Sorbaria aitchisoni. Kashmir False Spiraea. 8'

\begin{tabular}{|c|}
\hline to $4 \mathrm{ft}$. \\
\hline to $5 \mathrm{ft}$. \\
\hline to $6 \mathrm{ft}$. \\
\hline
\end{tabular}

glabrata. $8^{\prime}$

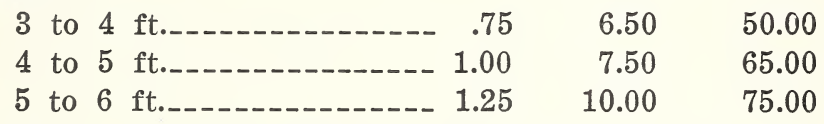

lindleyana. Lindley False Spiraea. $8^{\prime}$

\begin{tabular}{|c|c|c|}
\hline 3 ft... & .55 & 4.00 \\
\hline 3 to 4 ft...... & .65 & 5.00 \\
\hline 4 to $5 \mathrm{ft}$. & .75 & 5.50 \\
\hline
\end{tabular}

sorbifolia. Ural False Spiraea. 4'

2 to 3 ft._._._._._._- .60

3 to 4 ft.-_-_-_- 75

$5.00 \quad 40.00$

4 to $5 \mathrm{ft.}$.

$5.50 \quad 45.00$

$6.50 \quad 55.00$

Spiraea arguta. Garland Spiraea. $6^{\prime}$

\begin{tabular}{|c|c|c|}
\hline 2 to 3 ft.-. & .50 & 4.00 \\
\hline 3 to 4 ft...-- & .65 & 5.00 \\
\hline to $5 \mathrm{ft}$. & .70 & 5.50 \\
\hline to $6 \mathrm{ft.}$ & 1.00 & 7.50 \\
\hline
\end{tabular}

aitchisoni. (See Sorbaria).

billiardi. Billiard Spiraea. $6^{\prime}$

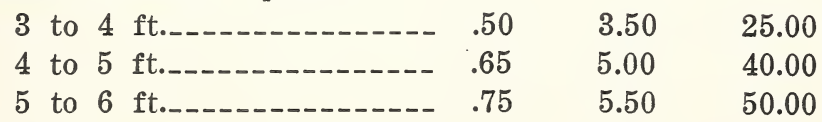

bumalda. Bumalda Spiraea. $3^{\prime}$

\begin{tabular}{|c|c|c|c|c|}
\hline 18 & to 24 & - & .50 & 4.00 \\
\hline 24 & to 3 & in..- & .65 & 5.00 \\
\hline $2 \frac{1}{2}$ & to & ft... & .75 & 6.00 \\
\hline
\end{tabular}




\section{Spiraea}

bumalda Anthony Waterer.

Anthony Waterer Spiraea. $3^{\prime}$ each per 10 per 100

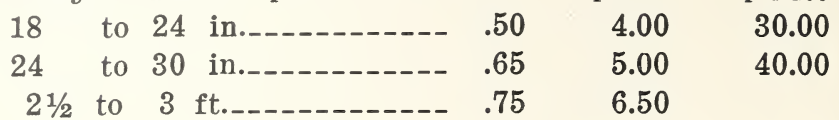

bumalda walluffi. $3^{\prime}$

$\begin{array}{llll}18 \text { to } 24 \text { in. } & 65 & 5.00 & 40.00 \\ 24 \text { to } 30 \text { in. } & .75 & 5.50 & 45.00\end{array}$

callosa alba. (See japonica ovalifolia).

chamaedryfolia ulmifolia. Elmleaf Spiraea. $6^{\prime}$

2 to 3 ft._._. $55 \quad 4.50$

douglasi. Douglas Spiraea. $8^{\prime}$

\begin{tabular}{|c|c|c|}
\hline 2 to $3 \mathrm{ft}$ & .45 & 3.00 \\
\hline 3 to 4 ft...-- & .50 & 3.50 \\
\hline 4 to 5 ft.-- & .60 & 4.50 \\
\hline to $6 \mathrm{ft}$. & .75 & 6.00 \\
\hline
\end{tabular}

fortunei. Fortune Spiraea. 4'

\begin{tabular}{|c|c|c|c|}
\hline 2 to $3 \mathrm{ft}$. & .45 & 3.00 & 25.00 \\
\hline 3 to $4 \mathrm{ft}$. & .50 & 4.50 & 40.00 \\
\hline 4 to $5 \mathrm{ft.}$ & .65 & 5.50 & 50.00 \\
\hline 5 to $6 \mathrm{ft.}$ & .85 & 7.00 & 60.00 \\
\hline
\end{tabular}

froebeli. Froebel Spiraea. 4'

\begin{tabular}{|c|c|c|}
\hline to $3 \mathrm{ft}$. & .50 & 4.00 \\
\hline 3 to $4 \mathrm{ft}$. & .65 & 5.00 \\
\hline
\end{tabular}

japonica ovalifolia. White Japanese Spiraea. 3'

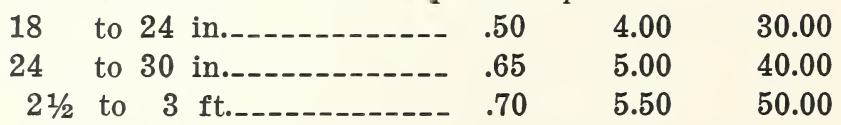

japonica ruberrima. Pink Japanese Spiraea. $5^{\prime}$

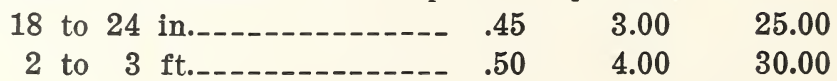

latifolia. Pink Meadow Spirea. $6^{\prime}$

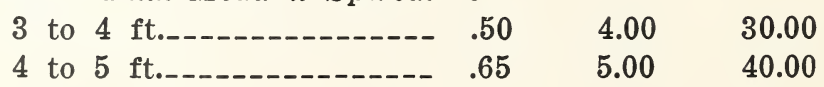

lindleyana. (See Sorbaria).

margaritae. Margarita Spiraea. $5^{\prime}$

2 to $3 \mathrm{ft.}$

$4.00 \quad 30.00$

3 to 4 ft._. $.60 \quad 500 \quad 40.00$ 


\section{Spiraea}

nipponica rotundifolia. Big Nippon Spiraea. 10'

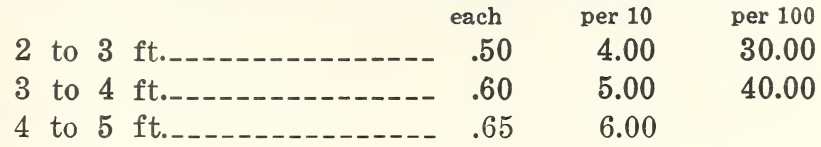

prunifolia. Bridal Wreath. $8^{\prime}$

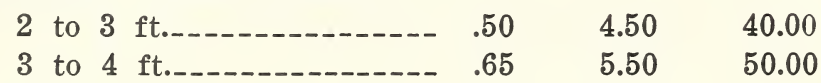

reevesiana. Reeves Spiraea. 8'

\begin{tabular}{|c|c|c|}
\hline to $3 \mathrm{ft.}$ & .50 & 4.00 \\
\hline 3 to $4 \mathrm{ft}$. & .60 & 4.50 \\
\hline 4 to $5 \mathrm{ft}$. & .65 & 5.00 \\
\hline to $6 \mathrm{ft.}$. & .75 & 6.50 \\
\hline
\end{tabular}

reevesiana fl. pl. Double Reeves Spiraea. $8^{\prime}$

\begin{tabular}{|c|c|c|}
\hline to $3 \mathrm{ft}$. & .50 & 4.00 \\
\hline 3 to $4 \mathrm{ft.}$ & .65 & 5.00 \\
\hline 4 to $5 \mathrm{ft}$. & .75 & 6.00 \\
\hline -._-_- & 1.00 & 7.50 \\
\hline
\end{tabular}

salicifolia. Willowleaf Spiraea. $5^{\prime}$

\begin{tabular}{|c|c|c|}
\hline 2 to $3 \mathrm{ft}$. & .45 & 3.00 \\
\hline 3 to $4 \mathrm{ft}$. & .50 & 3.50 \\
\hline 4 to $5 \mathrm{ft}$. & .65 & 5.00 \\
\hline to $6 \mathrm{ft}$. & .75 & 6.00 \\
\hline
\end{tabular}

sorbifolia. (See Sorbaria).

superba. Striped Spiraea. ' "'

24 to 30 in..... $65 \quad 5.00$

syringiflora. Lilac Spiraea. $3^{\prime}$

18 to 24 in..-.-_-_- $.50 \quad 4.00 \quad 35.00$

2 to 3 ft._._._._._.- $.60 \quad 4.50 \quad 40.00$

thunbergi. Thunberg Spiraea. 5'

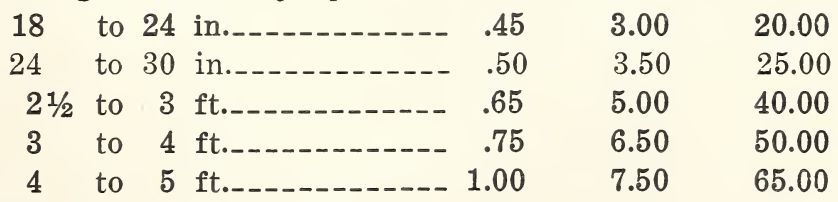

tomentosa. Hardhack. 4'

2 to 3 ft._._-_-_-_-_-_- .50

$4.00 \quad 30.00$

3 to 4 ft.-_-_-_-_-_-_-- $.60 \quad 4.50 \quad 40.00$

4 to 5 ft._-_-_-_-_-_-_- $.75 \quad 5.00$ 


\section{Spiraea}

van houttei. Vanhoutte Spiraea. ${ }^{\text {each }} 10^{\prime}$ per 10 per 100

2 to $3 \mathrm{ft} .45$

$3.00 \quad 20.00$

3 to 4 ft.-_-_-_-_.-. .50

$3.50 \quad 25.00$

4 to 5 ft......-...-..-. .65

$5.00 \quad 40.00$

5 to $6 \mathrm{ft.}$.-_-_-_-_-_-_-_. .75

$6.00 \quad 50.00$

Staphylea bumalda. Bumalda Bladdernut. $8^{\prime}$

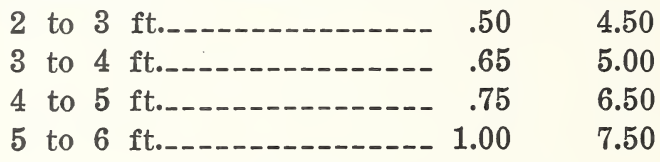

colchica. Colchis Bladdernut. 12'

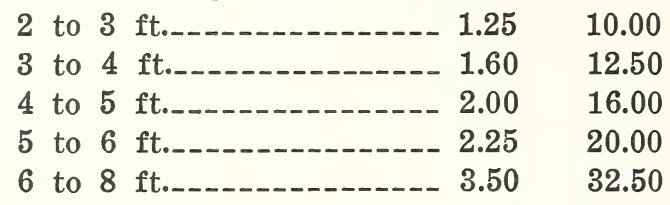

pinnata. European Bladdernut. 12'

3 to 4 ft._._._._._._. $.65 \quad 5.00$

4 to 5 ft.-_-_-_-_- $75 \quad 6.50$

5 to 6 ft._._._._._._._. $1.00 \quad 7.50$

6 to 8 ft._._._._._. $1.25 \quad 10.00$

trifolia. American Bladdernut. 12'

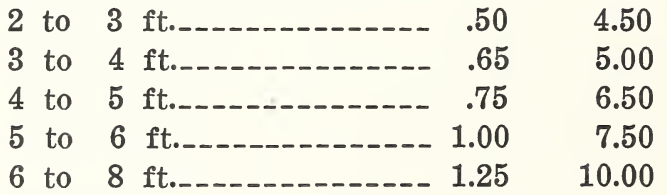

Stephanandra flexuosa. Cutleaf Stephanandra. $6^{\prime}$

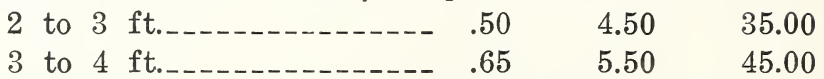

Stewartia pentagyna. Mountain Stewartia. 15'

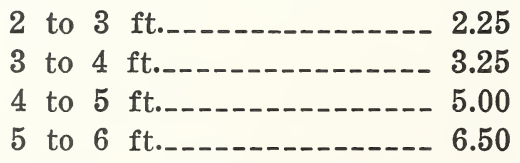

Styrax japonica. Japanese Snowbell. 20'

\begin{tabular}{|c|c|}
\hline 2 to 3 ft......... & 5.00 \\
\hline 3 to $4 \mathrm{ft}$. & 6.50 \\
\hline 4 to $5 \mathrm{ft.}$ & 10.00 \\
\hline 5 to $6 \mathrm{ft.}$ & 12.50 \\
\hline
\end{tabular}




\section{Syringa}

josikaea. Hungarian Lilac. 10'

\begin{tabular}{|c|c|c|c|}
\hline & each & per 10 & per 100 \\
\hline 2 & o 3 ft.-1-15 & 6.00 & 50.00 \\
\hline $3 \mathrm{t}$ & $04 \mathrm{ft} . \mathrm{o}-\mathrm{n}$ & 7.50 & 60.00 \\
\hline 4 & o 5 ft........ & 10.00 & 75.0 \\
\hline & o $6 \mathrm{ft}$. & 20.00 & \\
\hline & $8 \mathrm{ft.}$ & 25.00 & \\
\hline
\end{tabular}

pekinensis. Peking Lilac. 15 $^{\prime}$

\begin{tabular}{|c|c|}
\hline 2 to $3 \mathrm{ft}$ & 5.00 \\
\hline 3 to $4 \mathrm{ft}$. & 6.50 \\
\hline 4 to $5 \mathrm{ft}$. & 7.50 \\
\hline to $6 \mathrm{ft}$. & 10.00 \\
\hline to $8 \mathrm{ft.}$ & 12.50 \\
\hline
\end{tabular}

6 to $8 \mathrm{ft}$. specimens_-_.-- 4.50

persica. Persian Lilac. 10'

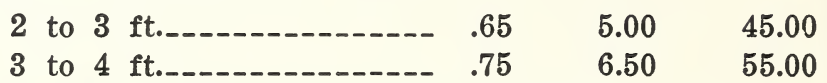

persica alba. White Persian Lilac. 10'

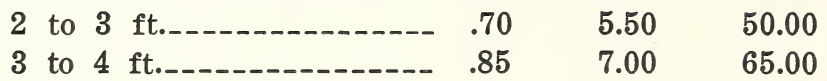

villosa. Late Lilac. $8^{\prime}$

\begin{tabular}{|c|c|c|}
\hline ft. & .60 & 5.00 \\
\hline to $4 \mathrm{ft}$. & 1.00 & 7.00 \\
\hline 5 ft.---n- & 1.25 & 10.00 \\
\hline to $6 \mathrm{ft}$. & 2.50 & 20.00 \\
\hline
\end{tabular}

vulgaris. Common Purple Lilac. 15'

\begin{tabular}{|c|c|c|}
\hline 2 to $3 \mathrm{ft}$. & .50 & 4.00 \\
\hline 3 to $4 \mathrm{ft}$. & .65 & 5.00 \\
\hline 4 to $5 \mathrm{ft}$. & .75 & 6.50 \\
\hline to $6 \mathrm{ft}$. & 1.25 & 10.00 \\
\hline ft. clumps_-_--- & 4.00 & \\
\hline
\end{tabular}

vulgaris alba. Common White Lilac. 15'

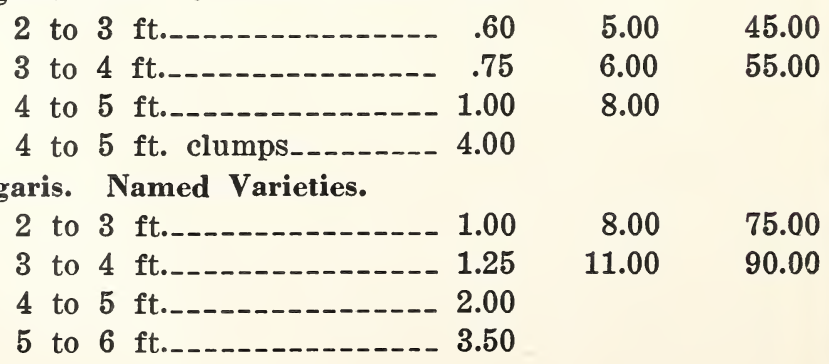


Syringa Belle de Nancy-Double Rose.

$2-3^{\prime} \quad 3-4^{\prime} \quad 4-5^{\prime}$

Chas. Joly-Dark Purplish Red.

$2-3^{\prime} \quad 3-4^{\prime}$

Frau Dammann-Single White.

$2-3^{\prime} \quad 3-4^{\prime}$

La Tour d'Auvergne-Double Purple.

$2-3^{\prime} \quad 3-4^{\prime} \quad 4-5^{\prime}$

Ludwig Spaeth-Single Red.

$2-3^{\prime} \quad 3-4^{\prime}$

Mad. Abel Chatenay-Double White.

$2-3^{\prime} \quad 3-4^{\prime} \quad 4-5^{\prime}$

Mad. Casimer Perier-Double Creamy White.

$2-3^{\prime} \quad 3-4^{\prime} \quad 4-5^{\prime}$

Mad. Lemoine-Large Double White.

$2-3^{\prime} \quad 3-4^{\prime} \quad 4-5^{\prime}$

Marie Le Graye-Single White.

$2-3^{\prime} \quad 3-4^{\prime}$

Pres. Grevy-Double Blue.

$2-3^{\prime} \quad 3-4^{\prime} \quad 4-5^{\prime} \quad 5-6^{\prime}$

Princess Alexandra-Single White.

$2-3^{\prime} \quad 3-4^{\prime} \quad 4-5^{\prime}$

We have a limited quantity of the newer varieties of Lemoine's hybrid named lilacs, which we offer as follows. A list of varieties will be forwarded on request.

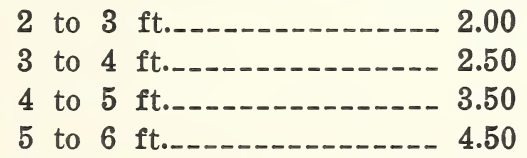

Tamarix africana. African Tamarix. $15^{\prime}$

\begin{tabular}{|c|c|c|c|}
\hline - & $\begin{array}{r}\text { each } \\
.50\end{array}$ & $\begin{array}{r}\text { per } 10 \\
3.50\end{array}$ & $\begin{array}{r}\text { per } 100 \\
30.00\end{array}$ \\
\hline - - - - - - - - - & .65 & 5.00 & 40.00 \\
\hline to $6 \mathrm{ft}$. & .75 & 5.50 & 50.00 \\
\hline to $8 \mathrm{ft} .--$ & 1.00 & 6.50 & \\
\hline
\end{tabular}

gallica. French Tamarix. 10'

3 to $4 \mathrm{ft.}$.

$3.50 \quad 30.00$

4 to $5 \mathrm{ft}$.

$5.00 \quad 40.00$

5 to 6 ft._.

gallica indica. India Tamarix. 10'

3 to $4 \mathrm{ft.}$.

$5.50 \quad 50.00$

4 to $5 \mathrm{ft.}$.

$3.50 \quad 30.00$

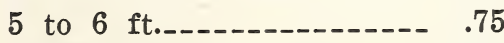

$5.00 \quad 40.00$

6 to $8 \mathrm{ft.}$

$5.50 \quad 50.00$

$6.50 \quad 55.00$


Tamarix.

odessana. Odessa Tamarix. $6^{\prime}$

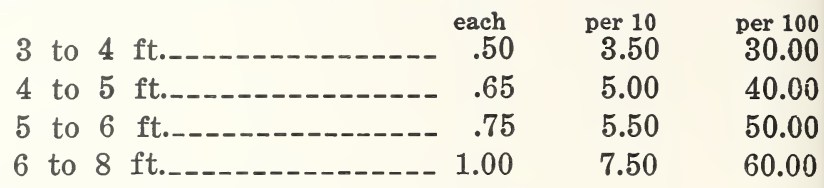

pentandra. Fivestamen Tamarix. 12'

3 to $4 \mathrm{ft.}$

$5.00 \quad 40.00$

4 to 5 1.00

6.50

50.00

5 to $6 \mathrm{ft}$

1.25

7.50

tetandra purpurea. Fourstamen Tamarix. 10'

3 to $4 \mathrm{ft.}$

Vaccinium corymbosum. Highbush Blueberry.

2 to 3 ft._-_-_-_-_B. \& B. $3.00 \quad 25.00$

Viburnum acerfolium. Mapleleaf Viburnum. $5^{\prime}$

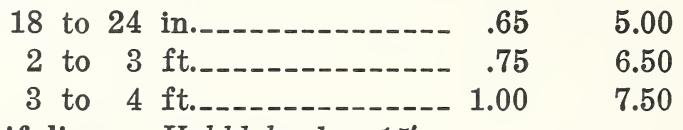

alnifolium. Hobblebush. 15'

2 to 3 ft.-_-_-_- $.55 \quad 4.00$

30.00

3 to $4 \mathrm{ft.}$.

americanum. American Cranberrybush. 10'

2 to $3 \mathrm{ft} . \ldots-\ldots 00$

45.00

3 to 4 ft._-_-_-_-_-_- $.75 \quad 6.50$

55.00

4 to $5 \mathrm{ft.} .-\ldots$

carlesi. Fragrant Viburnum. 4'

18 to 24 in.-_-_-_B. \& B. $3.00 \quad 25.00$

2 to 3 ft.-_-_-_-_B. \& B. $3.50 \quad 30.00$

cassinoides. Withe Rod. $6^{\prime}$

2 to $3 \mathrm{ft.}$.

50.00

3 to $4 \mathrm{ft.--a-c-1.00} \quad 7.50 \quad 65.00$

dentatum. Arrowwood. 12'

\begin{tabular}{|c|c|c|}
\hline 2 to $3 \mathrm{ft} .---$ & .50 & 4.00 \\
\hline 3 to $4 \mathrm{ft}$. & .60 & 5.00 \\
\hline 4 to $5 \mathrm{ft}$ & .75 & 6.00 \\
\hline 5 to $6 \mathrm{ft}$. & 1.00 & 7.50 \\
\hline 6 to $8 \mathrm{ft}$. & 1.25 & 10.00 \\
\hline
\end{tabular}

dilatatum. Linden Viburnum. 10'

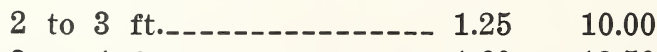

3 to $4 \mathrm{ft.}$.-_-_-_-_-_ $1.60 \quad 12.50$

lantana. Wayfaring Tree. 15'

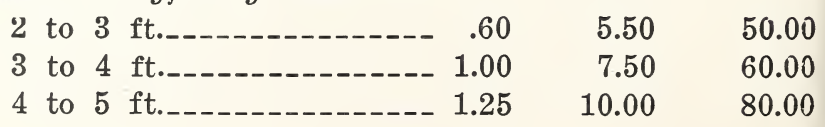




\section{Viburnum}

lentago. Nannyberry. 20'

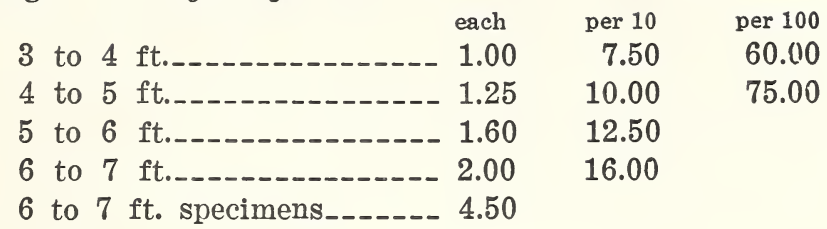

molle. Kentucky Viburnum. 10'

2 to 3 ft.
3 to 4 ft.
4 to 5 ft.
5 to 6 ft.

nudum. Smooth Withe Rod. $8^{\prime}$

2 to 3 ft._.
3 to 4 ft._.
4 to $5 \mathrm{ft} . \ldots \ldots$

opulus. High Bush Cranberry. 10'

2 to $3 \mathrm{ft.}$

3 to 4 ft._._._._._. 85

4 to $5 \mathrm{ft}$.

$6.00 \quad 50.00$

5 to $6 \mathrm{ft.}$

$7.00 \quad 60.00$
9.00

$9.00 \quad 80.00$

6 to $8 \mathrm{ft}$.

6 to $8 \mathrm{ft}$. specimens___._ 6.50

15.00

opulus nanum. Dwarf Cranberry bush. 2'

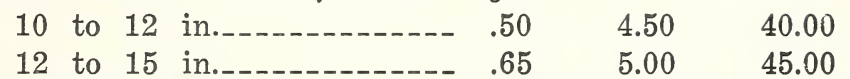

opulus sterile. Common Snowball. 10'

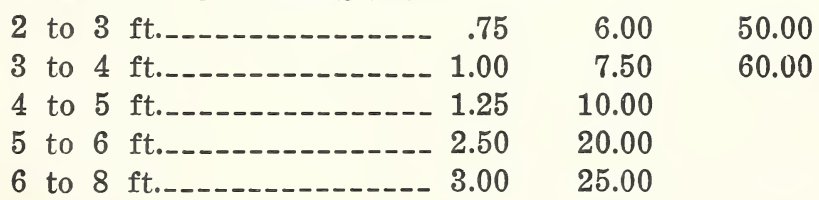

prunifolium. Blackhaw. 12'

3 to 4 ft._. $1.60 \quad 12.50$

4 to $5 \mathrm{ft}$.

pubescens. Downy Viburnum. $6^{\prime}$

2 to 3 ft.

3 to 4 ft._._. $1.25 \quad 10.00$

rhytidophyllum. Leatherleaf Viburnum. 8'

18 to 24 in._.___B. \& B. $3.25 \quad 25.00$

2 to $3 \mathrm{ft.} . \ldots$ B. \& B. $4.00 \quad 32.50$ 


\section{Viburnum}

rufidulum. Southern Blackhaw. 10'

$$
2 \text { to } 3 \text { ft._-_ each } \quad \begin{array}{lll}
\text { per } 10 & \text { per } 100
\end{array}
$$

sargenti. Sargent Cranberrybush. 10'

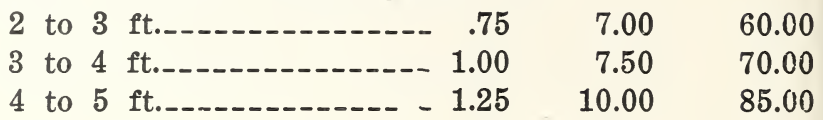

sieboldi. Siebold Viburnum. 10'

\begin{tabular}{|c|c|}
\hline$\ldots 1.25$ & 10.00 \\
\hline to $5 \mathrm{ft}$. & 12.50 \\
\hline ft._-_-_- 2.25 & 20.00 \\
\hline to $8 \mathrm{ft}$. & 25.00 \\
\hline
\end{tabular}

tomentosum. Doublefile Viburnum. $8^{\prime}$

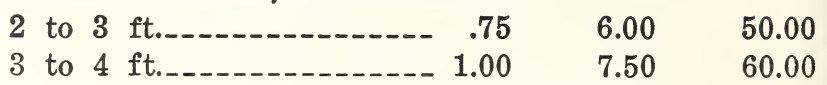

tomentosum plicatum. Japanese Snowball. $8^{\prime}$

\begin{tabular}{|c|c|}
\hline 2 to $3 \mathrm{ft}$. & 7.50 \\
\hline 3 to $4 \mathrm{ft.}$ & 10.00 \\
\hline 4 to $5 \mathrm{ft}$ & 16.00 \\
\hline 5 to $6 \mathrm{ft}$. & 20.00 \\
\hline
\end{tabular}

wrighti. Wright Viburnum. $8^{\prime}$

$$
\begin{aligned}
& 2 \text { to } 3 \text { ft._-_-_-_-_-_-_-_ } 1.25 \quad 10.00 \\
& 3 \text { to } 4 \mathrm{ft} .
\end{aligned}
$$

Vitex" agnus castus. Chaste-tree. 4'

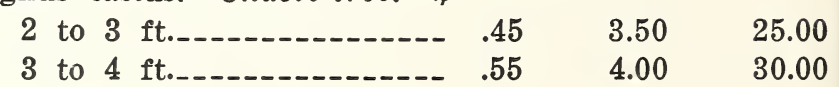

agnus castus alba. White Chaste-tree. 4'

\begin{tabular}{|c|c|c|}
\hline 2 to $3 \mathrm{ft}$ & .45 & 3.50 \\
\hline $4 \mathrm{ft.}$ & .60 & 4.50 \\
\hline $5 \mathrm{ft}$. & .75 & 5.50 \\
\hline 5 to $6 \mathrm{ft}$. & 1.00 & 7.50 \\
\hline
\end{tabular}

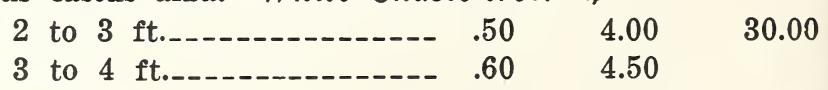

Weigela Abel Carriere. 10'

\begin{tabular}{|c|c|c|}
\hline to $3 \mathrm{ft} . \ldots$ & .45 & 3.50 \\
\hline to $4 \mathrm{ft}$. & .60 & 4.50 \\
\hline to $5 \mathrm{ft.}$ & .75 & 5.50 \\
\hline to $6 \mathrm{ft}$. & 1.00 & 7.50 \\
\hline
\end{tabular}

amabilis. Rose Weigela. $8^{\prime}$ 
Weigela

candida. Snow Weigela. 8' $^{\prime}$

\begin{tabular}{|c|c|c|c|}
\hline & each & per 10 & per 100 \\
\hline 2 to $3 \mathrm{ft}$. & .50 & 4.00 & 30.00 \\
\hline to $4 \mathrm{ft}$. & .65 & 5.00 & 40.00 \\
\hline to $5 \mathrm{ft}$ & .75 & 6.50 & 55.00 \\
\hline to $6 \mathrm{ft.}$. & 1.00 & 7.50 & \\
\hline
\end{tabular}

desboisi. Desbois Weigela. $8^{\prime}$

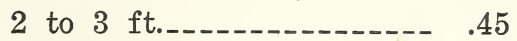

$3.50 \quad 25.00$

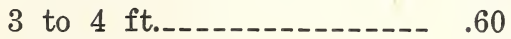

$4.50 \quad 35.00$

4 to $5 \mathrm{ft.} . \ldots$.

$5.50 \quad 45.00$

5 to $6 \mathrm{ft}$.

$7.50 \quad 65.00$

Eva Rathke. $5^{\prime}$

2 to $3 \mathrm{ft.}$
3 to $4 \mathrm{ft.}$

floribunda. Crimson Weigela. $8^{\prime}$

2 to 3 ft._._-_-_-_-_-_-_.-. .60

$4.50 \quad 35.00$

3 to $4 \mathrm{ft.}$._-_-_-_-_-_._- .75

$5.50 \quad 45.00$

groenewegeni. Greenway Weigela. 8'

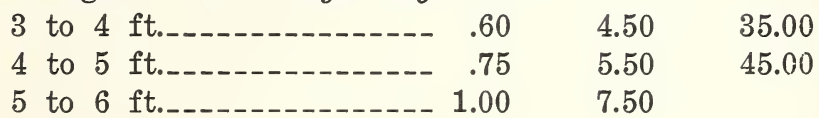

Gustav Mallot. $8^{\prime}$

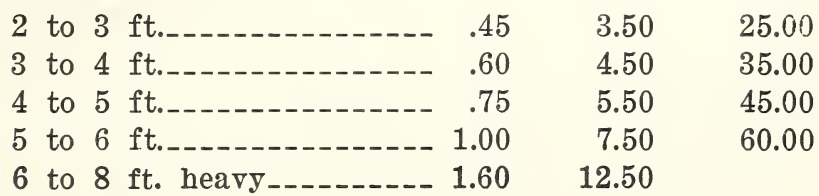

hortensis rubra. $8^{\prime}$

\begin{tabular}{|c|c|c|}
\hline to $3 \mathrm{ft.}$ & .45 & 3.50 \\
\hline 3 to $4 \mathrm{ft}$. & .60 & 4.50 \\
\hline ft. .... & .75 & 5.50 \\
\hline to $6 \mathrm{ft}$. & 1.00 & 7.50 \\
\hline
\end{tabular}

rosea. Pink Weigela. $8^{\prime}$

\begin{tabular}{|c|c|c|}
\hline 3 ft. & .45 & 3.50 \\
\hline $4 \mathrm{ft}$. & .60 & 4.50 \\
\hline------- & .75 & 5.50 \\
\hline - & 1.00 & 7.50 \\
\hline
\end{tabular}

rosea nana variegata. Dwarf Variegated Weigela. $5^{\prime}$
2 to $3 \mathrm{ft}$.
.45
3.50
25.00
3 to $4 \mathrm{ft}$.
$4.50 \quad 35.00$
4 to $5 \mathrm{ft}$
5.50
45.00 
Weigela

sieboldi argenteomarginata.

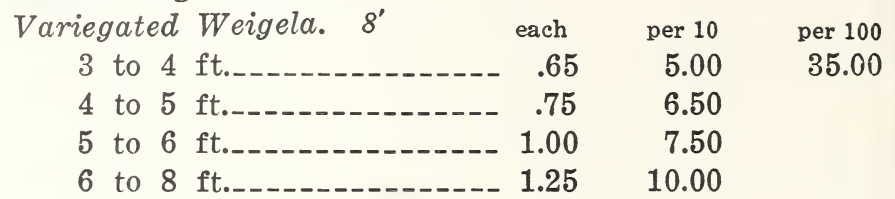

Vanhoutte. Van Houtte Weigela. $8^{\prime}$

\begin{tabular}{|c|c|c|}
\hline to $3 \mathrm{ft.}$ & .45 & 3.50 \\
\hline 4 ft._. & .60 & 4.50 \\
\hline to $5 \mathrm{ft.}$ & .75 & 5.50 \\
\hline
\end{tabular}

Xanthoceras sorbifolia. $10^{\prime}$

4 to 5 ft.-_ 5 to 6 ft.-_-

Zanthorhiza apiifolia. Yellowroot. $\Xi^{\prime}$

\begin{tabular}{|c|c|c|}
\hline 12 to 15 & .45 & 3.50 \\
\hline 5 to 18 in. clumps & .50 & 4.00 \\
\hline to 24 in. clumps.- & .65 & 5.00 \\
\hline
\end{tabular}

Zanthoxylum americanum. Prickly Ash. 15'

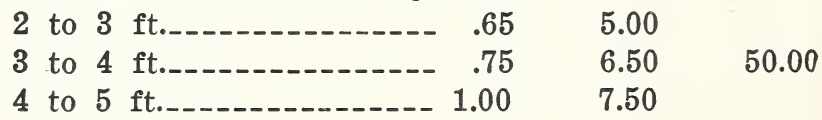

\section{Vines}

Actinidia arguta. Bower Actinidia.

2 year --_-_-_-_-_-_-_. .75

$6.00 \quad 50.00$

polygama. Silver Vine.

2 year --_-_-_-_-_-_-- $1.00 \quad 7.50$

Akebia quinata. Fiveleaf Akebia.

$\begin{array}{lllll}2 & \text { year } \\ 3 & \text { year } \\ \end{array}$

Ampelopsis aconitifolia. Monkshood Vine.

2 year --_-_-_-_-_-_-_. .45

$3.50 \quad 25.00$

3 year -.-_-_-_-_-_-_. $.50 \quad 4.00$ 30.00

heterophylla. Porcelain Ampelopsis.

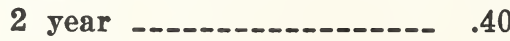

3.00

20.00

3 year --_-_-_-_-_-_-_- .50

3.50

25.00

4 year -_-_-_-_-_-_-_- .65

5.00

40.00

heterophylla variegata, syn. sieboldi.

2 year _-_-_-_-_._-_._._. .50

$4.00 \quad 30.00$

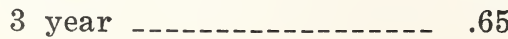

5.00

40.00 
Ampelopsis

quinquefolia. Virginia Creeper.

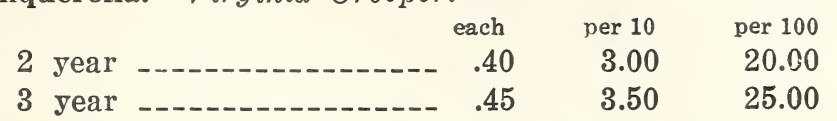

quinquefolia engelmanni. Englemann Creeper.

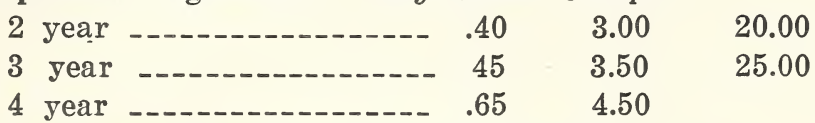

quinquefolia saintpauli. St. Paul Creeper.

2 year -_-_-_-_-_ $1.00 \quad 6.50 \quad 50.00$

tricuspidata syn. veitchi. Boston Ivy.

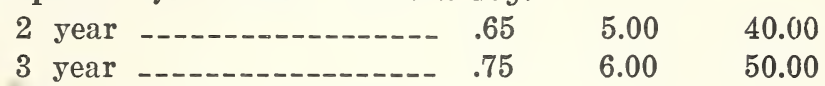

tricuspidata lowi. Geranium Ivy.

2 year, from pots _...-_- $1.10 \quad 10.00 \quad 80.00$

Aristolochia sipho. Dutchman's Pipe.

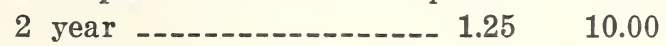

Bignonia grandiflora. Chinese Trumpetcreeper.

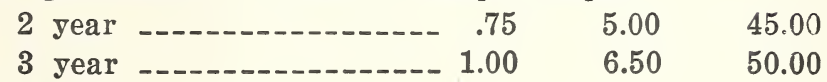

radicans. Trumpetcreeper.

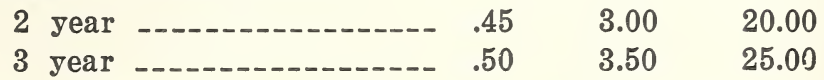

speciosa rubra. Painted Trumpetcreeper.

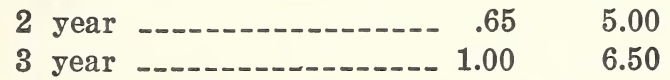

Celastrus articulatus. Japanese Bittersweet.

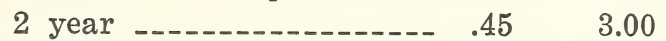

25.00

3 year - -

4 year -

scandens. Native Bittersweet.

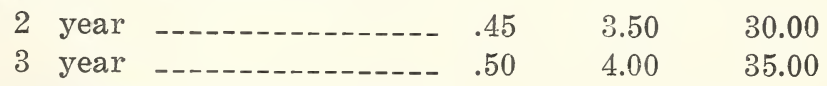

Clematis apiifolia. October Clematis.

2 year -

coccinea. (See texensis).

hybrids. Large Flowering Clematis.

2 year -

Jackmanni, Mad. Ed. Andre, Henryi,

Duchess of Edinburg. orientalis. Oriental Clematis.

2 year - 


\section{Clematis}

paniculata. Sweet Autumn Clematis.

\begin{tabular}{|c|c|c|c|}
\hline & each & per 10 & per 100 \\
\hline year & .40 & 3.00 & 20.00 \\
\hline 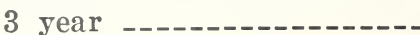 & .50 & 3.50 & 25.0 \\
\hline
\end{tabular}

tangutica. Golden Clematis.

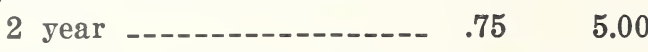

45.00

texensis syn. coccinea. Scarlet Clematis.

2 year -_-_-_-_-_._- $.65 \quad 5.00$

virginiana. Virgins-bower.

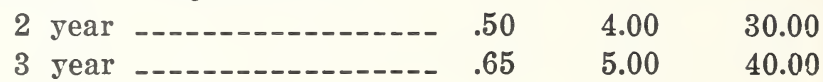

Hedera helix. English Ivy.

2 year, 4 in. pots___-_-_- $\quad .60 \quad 5.00 \quad 40.00$

3 year, 4 in. pots__-_-_-_ $1.00 \quad 7.50 \quad 50.00$

helix gracilis. Small-leaved English Ivy.

2 year, 3 in. pots_-_-_-_- $.60 \quad 5.00 \quad 40.00$

3 year, 3 in. pots_-_-_-_-_ $1.00 \quad 7.50 \quad 50.00$

Lonicera caprifolium. Sweet Honeysuckle.

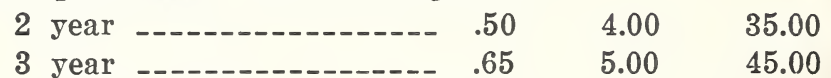

browni plantieriensis. Orange Honeysuckle.

2 year -

45.00

heckrotti. Everblooming Honeysuckle.

2 year -..--

35.00

henryi. Honeysuckle.

2 year -

50.00

hirsuta. Hoary Honeysuckle.

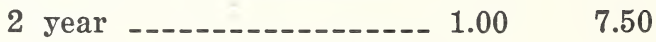

japonica. Japanese Honeysuckle.

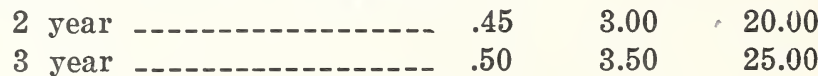

japonica halleana. Hall Japanese Honeysuckle.

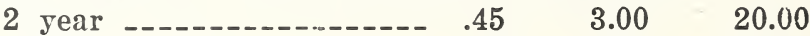

3 year --_-_-_-_-_-_- $\quad .50 \quad 3.50 \quad 25.00$

japonica reticulata aurea.

Yellow Japanese Honeysuckle.

2 year _-_._-_._-_-_. $.45 \quad 3.50 \quad 25.00$

periclymenum belgica. Dutch Woodbine.

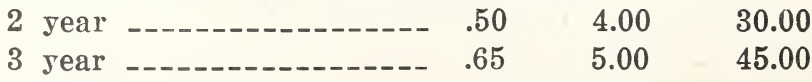




\section{Lonicera}

prolifera syn. sullivanti. Grape Honeysuckle. each per 10

3 year --_-

sempervirens. Trumpet Honeysuckle.

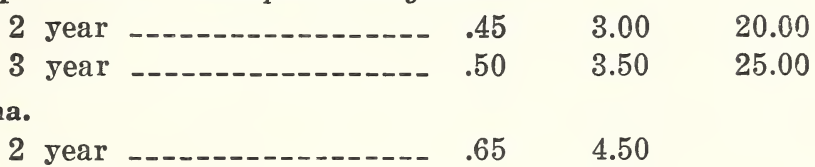

Lycium. (See Shrubs).

Periploca graeca. Silk Vine.

\begin{tabular}{|c|c|}
\hline 2 year & 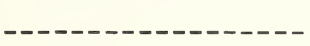 \\
\hline 3 year & 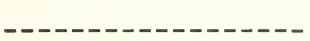 \\
\hline 4 year & 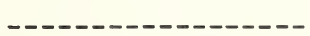 \\
\hline
\end{tabular}

Polygonum auberti. China Fleecevine.

2 year

baldschuanicum. Silver Fleecevine.

2 year _. 7.50

Pueraria thunbergiana. Kudzu-bean.

2 year

Schizophragma hydrangeoides.

Japanese Hydrangea-vine.

from pots

Solanum dulcamara. True Bittersweet.

2 year -

$3.00 \quad 20.00$

Tecoma. (See Bignonia).

Vinca minor. Periwinkle.

8 to 12 in. 10.0 Q

minor alba. White Periwinkle.

2 year -

minor rubra plena. Dbl. Red Periwinkle.

2 year _-_-_- $50 \quad 4.00 \quad 35.00$

Vitis aestivalis. Summer Grape.

$\begin{array}{lllll}2 \text { year } & & & \\ 3 & \text { year } & & & \\ \end{array}$

coignetiae. Gloryvine.

2 year

cordifolia. Frost or Winter Grape.

2 year _.......... 45

$3.50 \quad 25.00$

3 year

$4.00 \quad 30.00$


Vitis

$\begin{array}{rrrr}\text { labrusca. Fox Grape. } & \text { each } & \text { per } 10 & \text { per } 100 \\ 2 \text { year } & .45 & 3.50 & 25.00 \\ 3 \text { year } & .50 & 4.00 & 35.00\end{array}$

vulpina. Riverbank Grape.

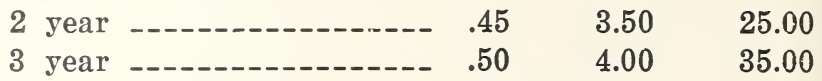

Wistaria frutescens. American Wistaria.

2 year _.

3 year _.. $65 \quad 5.00 \quad 40.00$

frutescens magnifica. Yelloweye Wistaria.

2 jear _._.

3 year _-_- $65 \quad 5.00 \quad 40.00$

multijuga. Japanese Wistaria.

2 year

sinensis. Chinese Purple Wistaria.

2 year

$5.50 \quad 50.110$

3 year _.

3. to $4 \mathrm{ft}$. standard____.- $1.60 \quad 12.50$

4 to $5 \mathrm{ft}$. standard__._._ $2.50 \quad 20.00$

sinensis alba. Chinese White Wistaria.

\begin{tabular}{|c|c|}
\hline 2 year & - \\
\hline year & $-----n-$ \\
\hline
\end{tabular}

\section{Hardy Perennials}

Young transplanted, field grown stock

Acanthus mollis. Purple Rose, July, 4'_.. $\$ 2.50$ mollis latifolius. Rose, July, 2-3'_--- 2.50

Achillea ageratum. Yellow, July, 1'_... 1.50

filipendulina. Yellow, June, July, 3'_- $1.50 \quad 12.00$ millefolium Cerise Queen. Rose, July, 2' _... $1.50 \quad 12.00$

ptarmica fl. pl. White, July, 2'__-- $1.50 \quad 12.00$ ptarmica Boule de Neige. White, June, July, 2' _.... $1.50 \quad 12.00$

ptarmica Perry White. June, July, 2'_-- $1.50 \quad 12.00$ tomentosa. Yellow, June, 1'_._._. $1.50 \quad 12.00$ 
per 10

Aconitum autumnale. Blue, July, August, 4' 3.00 japonicum. Violet, summer, $2^{\prime}$

Aegopodium podagraria variegatum.

Variegated foliage, 1'_._. 1.50

12.00

Agrostemma. (See Lychnis).

Ajuga genevensis. Bright blue, May, 6" 1.50

12.00 reptans. Blue, May, 6" 6 ... 1.50

Althea rosea. Hollyhock.

Double. Separate colors, July, Aug., 5'

Double. Chater's strain, separate colors

Fringed Allegheny. July, August, 5'

Single. Mixed colors, July, Aug., 5'_--

Amsonia tabernaemontana. Blue,

$$
\text { May, June, 3' _._. } 1.50
$$

Anchusa capensis. Blue, all summer, 11/2'-japonica Geante des Blanches.

White, Fall, 3' japonica Lady Ardilaun.

White, Fall, 4' 4.50 japonica Prince Heinrich.

Deep pink, Fall, 3' japonica Queen Charlotte. 
Anemone

japonica Rose d'Autumn.

per 10

Pink, Fall, 3'

per 100

japonica rubra. Red, Fall, 2'

2.50

22.00

japonica Whirlwind. Pure white, Fall, $3{ }^{\prime} \quad 2.50$

22.00

penrsylvanica. White, July, 11/2'_-_-_. 1.50

pulsatilla. Blue, April, 15" _._._._._ 1.80

22.00

pulsatilla rubra. Dark red, April, 12" 1.80

15.00

15.00

Anthemis tinctoria. Yellow, July, Aug., 3'_- 1.50

12.00

tinctoria E. C. Buxton.

Lemon yellow, July, Aug., 3'_-..- 2.50

20.00

tinctoria kelwayi. Yellow, July, Aug., 3' 1.50

12.00

Aquilegia alpina. Blue, May, June, 1'_-_- 1.50

12.00

caerulea. Blue, May, June, 11/2' _..- 2.20

18.00

caerulea helenae. Blue, May, June, 2'-- 1.80

15.00

caerulea hybrida. Various, June, 2'-- 1.50

canadensis. Scarlet, May, June, 2'_-.- 1.50

12.00

californica. (See formosa truncata.)

chrysantha. Yellow, June, July, 3'_-_- 1.80

chrysantha alba. White, June, July, 3' 1.80

formosa truncata. Various, June, 2'-- 1.50

12.00

glandulosa. Lilac blue, June, 11/2' -.-- 1.50

hybrida. Mrs. Scott Elliott.

Various, June, 2'

2.20

monstrosa ff. pl. Pink, June, 2'_-_-- 2.50

rosea. Long spurred pink, June, 2'_-.- 1.80

rosea fl. pl. Dbl. Pink, June, 18" -.-- 2.20

skinneri. Red and yellow, May 2'-.-- 1.50

vulgaris. Purple, May, June, 2'_...- 1.50

vulgaris nivea. White, May, 2'_...-- 1.50

vulgaris olympica. Purple, May, June, 2' 1.50

Arabis alpina. White, April, May, 6"-_-- 1.80

Arenaria balearica. White, July, Aug., 3" 2.50

montana. White, May, 4" _._-_._-_- 2.50

15.00

15.00

12.00

12.00

18.00

20.00

15.00

12.00

12.00

12.00

12.00

15.00

22.00

20.00

Arisaema dracontium. Purple, May, 1'_..- 1.50

12.00

Armeria cephalotes rubra.

Bright pink, May, June, 6"

18.00

12.00

laucheana. Crimson, May, June, 8"-- 1.50

martima. Pink, May, June, 6"_._._- 1.50

12.00

maritima alba. White, May, June, 6" 1.50

12.00

mauritanica. Pink, July, August, 8"-- 1.50

12.00

robusta. Crimson, May, June, 6"-_._- 1.50

12.00

Less than five at double the rate per hundred. 
Artemisia abrotanum. Fragrant foliage, 5' argentea. Silver foliage, 2' _.....-.amellus Rud. Goethe.

Lavender blue, Fall, 2'

Anita Ballard. Soft lavender, Fall, 4' Beauty of Colwall. Fine blue, Sept., 3'

Beauty of Orleans. Bright mauve, Fall, 4' Blanchette. Mauve blush, Fall, $4^{\prime} \ldots$ Climax. Blue, Sept., Oct., 3'_..... diplostephioides. Blue, July, 2' Feltham Blue. Blue, Sept., Oct., 3'_..grandiflorus. Dark violet, Sept., 3'_-.Heather Glow. Rose, Fall, 4' _..... ibericus ultramarin. Dark blue, Sept., 3' Joan Vaughan. Dbl. Mauve-blue, Sept., 3' laevis. Lavender, Sept., 4' Mad. Emil Thoury. Violet, Sept., 5' Mad. Soyneuse. Light blue, Sept., Oct., 3' Mauve Cushion. Mauve, Oct. 12" Mrs. Raynor. Crimson, Sept., $3^{\prime} \ldots$ novae-angliae. Purple, Sept., Oct., 4' novae-angliae roseus. Rose, Sept., 4' Robt. Parker. Lavender, Sept., Oct., 5' Rue des Hatives. Rose mauve, Fall, 3' Snow Queen. White, Sept., Oct., 4'_--St. Egwyn. Soft pink, Sept., Oct., 3'_tataricus. Purple, Oct. and Nov., 6'_-

White Climax. White, Fall, 4'_._._. 1.50
2.50

2.50

20.30

20.00

12.00

2.50

2.50

1.50

1.80

1.50

3.50

3.00

2.50

2.50

1.50

3.00

1.50

2.50

1.80

1.50

20.00

12.00

15.00

12.00

25.00

20.00

12.00

25.00

12.00

1.80

1.50

3.00

1.50

1.50

1.50

\subsection{0}

15.00

12.00

25.00

12.00

12.00

12.00

12.00

Less than five at double the rate per hundred. 
Astilbe arendsi Ceres. Rosy Lilac, July, 2' 3.50 arendsi Juno. Purplish pink, July $3^{\prime}--$ arendsi Kreimhilde. Rose, June, July, 2' arendsi Moerheimi. White, July, 3' arendsi Rose Pearl. Shell pink, July, 3' rosea Queen Alexandra.

Deep pink, July, 3'

3.50

30.00

30.00

rosea Queen of Holland

Rose pink, July, 3'

3.50

30.00

rubella Solferino. Violet pink, July, 3'

3.50

30.00

rubella Vesta. Lilac rose, July, $3^{\prime} \ldots-$ - 3.50

30.00

30.00

Astrantia major. Silvery pink, May, 2'_- 2.20

18.00

Aubrietia deltoidea bougainvillei.

Dark blue, Apr., 5" _._._._. 2.50

22.00

deltoidea leichtlini. Pink, April, 5"_-- 2.50

22.00

deltoidea purpurea. Purple, April, 5"

22.00

Baptisia australis. Indigo, June, $4^{\prime} \ldots \ldots . .-1.80$

15.00

tinctoria. Yellow, June, 3'

15.00

Belamcanda chinensis. Orange, June, 11/2' 1.50

12.00

Bellis perennis alba. White, April, May, 3" 1.50

12.00

perennis rosea. Pink, April, May, 3" 1.50

12.00

Betonica. (See Stachys.)

Bocconia cordata. Creamy white, Aug., 6'_ 1.50

12.00

Boltonia asteroides. White, Sept., 5'

12.00

latisquama. Lavender, August, 5'

12.00

Buphthalmum speciosum. Yellow, June, 3' 1.50

12.00

Callirhoe involucrata. Red, all summer, 6" 1.50

12.00

Camassia Quamash. Blue, May, 2' _...-- 1.50

12.00

Campanula alliariaef olia.

White, June, July, 2'_.......... 1.80

15.00

carpatica. Blue, July, August, 9" _..- 1.80

15.00

carpatica alba. White, July, Aug., 9" -- 1.80

15.00

carpatica Raineri. Dark blue, July, 6" 2.50

grosseki. Blue, all summer, 2'_-_._-- 1.50

12.00

lactifiora. Light blue, August, 4'

12.00

latifolia. Purplish blue, July, 3' _.... 1.50

12.00

latifolia alba. White, July, 3'_-_._._- 1.50

12.00

latifolia macrantha.

Purplish blue, July, 3' _-_._-_._- 1.50

medium. Mixed, June, July, 3'_....- 1.50 
Campanula

medium. Separate colors, June, July, $3^{\prime} \quad \begin{array}{r}\text { per } 10 \\ 1.80\end{array}$

per 100 medium calycanthema. Mixed, July, 3' 1.50 15.00 medium calycanthema. Separate colors,

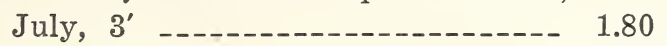
persicifolia. Blue, June, July, 2'-_- 1.80 persicifolia moerheimi. White, June, 2' 2.20 pyramidalis. Blue, July, 4-5' -..-_-- 1.80 pyramidalis alba. White, July, 4-5' rotundifolia. Blue, June, July, 12" _..- 2.50 trachelium. Blue, July, 2-3'

12.00

15.00 15.00 18.00 15.00 15.00 18.00 12.00

Carex morrowi. White-edged foliage, $1^{\prime}--2.50$ 18.00 Cassia marilandica. Yellow, July, 3-4'_--- 1.50 12.00 Catananche caerulea. Blue, June, July, 3' 1.50 bicolor. Blue, July, 2' _._._._._. 1.80 12.00 15.00 Caulophyllum thalictroides. --_--_-_----- 1.50 12.00

Centaurea babylonica. Yellow, July, 5'---- 1.50 dealbata. Red, July, 11/2'-_-_-_._- 1.80 gymnocarpa. Purple, July, 11/2'--.--macrocephala. Yellow, July, 3-4' -..- 1.50 montana. Blue, June, July, 2' ruthenica. Straw color, July, 4'

Centranthus ruber. Red, all summer, 3'-- 1.50 ruber albus. White, all summer, 3'-- 1.50 15.00 12.00 12.00 12.00 12.00 Cephalaria alpina. Yellow, July, 5' $5^{\prime}-{ }_{---} 1.50$ 12.00 Cerastium arvense compactum.

White, July, 8" -._-_-_-_- 1.50

biebersteini. White, June, 6" _-_._- 1.80 15.00 tomentosum. White, June, 6" 6 ..._._-_ 1.50 12.00

Ceratostigma plumbaginoides. Blue, Fall, 6" 1.80 15.00 Cheiranthus allioni. Yellow, July 2'_-_..- 1.50 12.00 Chelone glabra. White, or rose tinged,

$\begin{array}{cc}\text { July, 2' } & -1.50 \\ & \end{array}$

lyoni. Deep rose, August, 2' -.----- 1.50

Chrysanthemum anemone-flowered -..--- 1.80

Snow Queen-White.

arcticum. White, Fall, 2'
12.00

12.00

15.00

12.00

Less than five at double the rate per hundred. 


\section{Chrysanthemum}

$\begin{array}{llrr} & & \text { per } 10 & \text { per } 100 \\ \text { hardy button varieties } & 1.50 & 11.00\end{array}$

Baby Marguerite-pure white.

Bronze Button-bronze.

Brown Betty-maroon red.

Diana-yellow.

Golden Climax-yellow.

Irene-Pure white.

Kitty Barno-bronze.

Klondike-bright yellow.

Lillian Doty-pink.

Niza-delicate pink.

Rose Button-rose.

White Doty-white.

hardy large flowering, double, Fall, 4' 1.50

Border Beauty - orange, tipped with gold.

Boston-orange. .

Canariense-yellow.

Etna-red.

Favorite-buff.

Golden Queen-yellow.

L'Argentuillais-deep chestnut.

La Danube-pure pink.

Marie Antoinette-pink.

Old Homestead-buff.

Pacific Supreme-white, fading to rose.

Rosea-red.

Ruby King-brown red.

Ruth Cumming-reddish bronze.

Snowclad-white.

Glory of Seven Oaks, Yellow, Sept., 2' 1.80

Normandie. Pink, early Fall, 2'

Yellow Normandie. Yellow, early

Fall, 2' --_- 1.80

hardy large flowering, single. Fall, 4' 1.50

Astarte-amber.

Excelsior-golden yellow.

Lady Smith-bright pink.

Louise-salmon.

Mrs. W. E. Buckingham-salmon pink.

Less than five at double the rate per hundred. 
Chrysanthemum

maximum. White, all summer, 2'_--- 1.50

per 100

12.00

maximum Alaska. White, July-Aug., 2' 1.50

12.00

maximum King Edward. White,

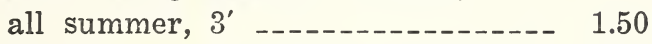

12.00

maximum Shasta. White, July-Aug., 2' 1.50

12.00

nipponicum. White, Fall, 2'_._._._- 2.20

Cimicifuga racemosa. White, July, 5'

12.00

simplex. White, Fall, 2' _._-_-_ 6.00

50.00

Clematis davidiana. Blue, August, $3^{\prime} \ldots-\ldots \quad 2.50$

20.00

recta. White, July, 3' $3^{\prime}$

25.00

Codonopsis clematidea. White, June, 2'

Convallaria majalis. Clumps, White, May, 6" 1.80

Coreopsis grandiflora. Yellow, all summer, $3^{\prime} \quad 1.50$

lanceolata. Yellow all summer, 2'_--- 1.50

1. Etoile d'Or. Dbl. yellow, summer, 2' 4.00

rosea. Rose, August, Sept., 1'____- 1.50

verticillata. Yellow, July, Aug., 2'_--- 1.50

15.00

11.00

11.00

35.00

12.00

12.00

Corydalis cheilanthifolia. Creamy white, July, 2' _._._. 3.50

30.00

Crucianella stylosa. Crimson pink, July, 8" 1.80

15.00

Delphinium belladonna. Sky blue, all summer, 4' _._._. 1.50

12.00

bellamosum. Dark blue, all summer, $4^{\prime}$

cashmerianum. Dark blue, July, $1^{\prime}$-- 2.20

18.00

chinense. Blue July, 2'_._._._._._-_ 1.50

12.00

chinense album. White, July 2' _...- 1.50

12.00

elatum. Blue July, 4'__________._ 1.50

formosum. Indigo, July, $4^{\prime}$ _........- 1.80

12.00

15.00

formosum coelestinum. Light blue,

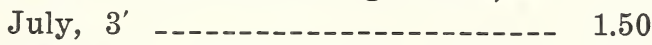

12.00

grandiflorum. Shades of blue, July, $3^{\prime} 1.50$ 12.00

grandiflorum Indigo. Dark blue, July, 4'

hybridum Blackmore and Langdon. Various, July, 4' -..--..-.--.

hybridum Gold Medal. Shades of blue, July, 4'

sibirica hybrida. Shades of blue,

July, $3^{\prime}$

Tess than five at double the rate per hundred. 
Dianthus allwoodi. Pink, July, 1'_-_r-- $\begin{array}{r}\text { per } 10 \\ 1.80\end{array}$

arenarius. White, July, $10^{\prime \prime} \ldots \ldots \ldots$

15.00

barbatus. (Single Sweet William).

mixed colors, June, July, 1'___.- 1.50

15.00

barbatus alba. White, June, July, 1'_- 1.50

barbatus atrococcineus. Crimson,

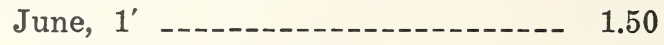

12.00

barbatus fl. pl. (Double Sweet William). mixed colors, June, July, 1'__._._ 1.50

barbatus Holborn Glory. Mixed, June, 1' 1.50

barbatus Newport Pink. Fine pink,

June, 1' -.--_-_-_-_-_-_-_-_-_- 1.50

12.00

barbatus nigricans. Dark velvety rea, June, $1^{\prime}$ _-_._. 1.50

barbatus rosea. Pink, June, $1^{\prime}$ _...-. 1.50

barbatus Salamoni. Salmon, June, 1' 1.50

barbatus Sutton's Scarlet. Crimson,

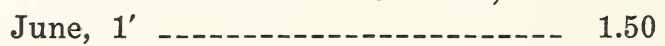

caesius. Rose pink, June, July, 9"-_-- 1.50

caryophyllus. Double, mixed, all summer, 9"

1.50

12.00

Chabaud. Pink, June, July, 12" _...-- 1.80

15.00

chinensis heddewigi. Mixed, June, July, $9^{\prime \prime}$

deltoides. Pink, June, 9"

1.50

12.00

1.50

12.00

diadematus. Pink, June, 10"

1.80

15.00

graniticus. Purple, July, 6"

1.80

hardy pinks. Single, mixed, all summer, $9^{\prime \prime}$

1.50

15.00

latifolius atrococcineus. Crimson, summer, 1'

1.50

12.00

plumarius. (Scotch Pink) mixed, summer, 8"

plumarius fl. pl. (Double Scotch Pink) mixed, all summer, 9"

plumarius semperflorens. Pink, June, 9"

1.80

15.00

1.50

12.00

Abbotsford. Crimson, all summer, 9"

1.80

15.00

Cyclops. Dark rose, June, July, 9"

1.50

12.00

Delicata. Rose, June, July, 9" -.--

2.20

18.00

Elizabeth Peters. Pink, June, July, 9"

1.80

15.00

Less than five at double the rate per hundred. 
Dianthus plumarius

Elsie. Bright rose, June, July, 9" $\begin{array}{r}\text { per } 10 \\ 2.20\end{array}$

per 100

Etoile de Lyon. Crimson, June, 1'-- 3.00

18.00

Homer. Rosy red, June, July, 9"-- 2.20

25.00

Her Majesty. Dbl. White, June, July, 9" 1.80

18.00

Souv. de. Sales. Dbl. Pink, June, 9" 1.80

15.00

Variegated Reserve.

White, mottled red, June, July 9" 2.20

15.00

White Reserve. White, June, July, 9" 1.80 speciosa. Pink, July, 10" superbus. Lilac, June, July, 12" -_-_ 1.80

18.00

15.00

15.00

15.00

Dicentra eximea. Rose, all summer, $1^{\prime}$-_-_ 2.50

18.00

Dictamnus albus. White, June, 2'

25.00

albus ruber. Red, June, 2' _-__-_-_ 3.00

Digitalis ambigua. Yellow, June, July, 3'-- 1.50

12.00

ferruginea. Yellow, July, 4-6' -_.-- 1.50

12.00

gloxinaeflora. Mixed, June, July, 3'-- 1.50

12.00

lanata. Creamy yellow, June, 3'-..-- 1.50

12.00

purpurea. Mixed, June, July, $3^{\prime}$-_-_-- 1.50

12.00

purpurea maculata. Spotted, June,

July, 18"

1.50

purpurea monstrosa. Various, June, July, $3^{\prime}$

purpurea, rose. June, July, $3^{\prime}$ _...-. 1.50

purpurea, white. June, July, 3'_-_.-- 1.50

12.00

12.00

12.00

12.00

Doronicum clusi. Yellow, Apr., May, 18" 4.00

30.00

plantagineum excelsum.

Yellow, Apr., May, 3'

30.00

Echinacea purpurea, Cone Flower. Reddish purple, July, August, 3' _...-.- 1.50

12.00

12.00

Echinops ritro. Deep steel blue, July, 3' 1.50

12.00

sphaerocephalus. Pale blue, July, 5'--

1.50

25.00

Elymus giganteus. Wild-rye, 3-4' --.---- 3.00

Epilobium angustifolium. Rose, August, 4' 2.20

Erianthus ravennae. Ravenna Grass, 6'--- 2.50

Erigeron coulteri. White, July, 15" --.-- 1.50

12.00

glabellus. Violet, June, July, 1'_-_-_ 1.50

12.00

glaucus. Mixed, June, July, 1' _-..-- 1.50

12.00

speciosus. Rich purple, June, July, 2' 1.50

12.00

Eryngium planum. Steel Blue, July, Aug., 3’ 1.50

12.00

Less than five at double the rate per hundred. 
per 10

per 100

Erysimum pulchellum. Lemon, May, June, 6" 1.50

12.00

Eulalia gracillima. Japan Rush, 4-6'_--- 1.50

12.00

japonica variegata. 4-6' _..-_-_-_ 1.80

15.00

zebrina. Zebra Grass, 4-6' _-_-_-_-- 1.80

15.00

Eupatorium ageratoides. White, August, 3' 1.50

12.00

coelestinum. Blue, Sept., Oct., 18"

1.50

fraseri. White, Aug., Sept., 18" _-_-_ 1.50

12.00

purpureum. Purple, Aug., Sept., 5'_-

1.50

Euphorbia corollata. White, July, Aug., 2' 1.80

12.00

12.00

cyparissias. Yellow, May, 2"

2.20

Festuca glauca. Fescue Grass, June, 10" 1.50

15.00

18.00

Fragaria indica. White, May, 6"_..... 1.80

12.00

Funkia. (See Hosta).

Gaillardia grandiflora. Yellow and Crimson, all summer, 2' _-_________-_ 1.50

15.00

grandiflora Bosseleari.

Yellow and crimson, all summer, 2' 1.80

11.00

Galega officinalis. Blue, June, July, $3^{\prime}$

1.50

15.00

officinalis hartlandi. Bluish White, July, $3^{\prime}$

Galium boreale. White, July, 11/2'

Gentiana alba. White, August, 2'_...- 1.80 andrewsi. Blue, August, 2' _.-.- 1.80

12.00

12.00

15.00

15.00

15.00

Geranium ibericum. Mauve blue, May, June, 2' _-...... 1.80

lancastriense. Mauve, May, June, 1'_-

pratense album. White, July, Aug., 2'

sanguineum. Red, June, July, 2'_... 1.50

Geum atrosanguineum. Dark red, all summer, $1 \frac{1}{2} 2^{\prime} \ldots \ldots 0$

Lady Strathedon. Orange,

all summer, 15"

Mrs. Bradshaw. Double red, all'summer, $1^{\prime} \quad 2.20$

22.00

18.00

12.00

Gypsophila acutifolia. Pink, July, 2-3'_-.- 1.50

12.00

paniculata. White, July, Aug., 2-3'_-- 1.50

paniculata fl. pl. Dbl. white, July,

$$
\text { Aug. 3' }
$$

repens. Bluish white, all summer, 4'_- 1.50

repens rosea. Pink, July, Aug., 2-3'_- 1.80

Helenium autumnale superbum. Yellow,

Sept., 5-6' _._._. 2.20

hoopesi. Orange, June, July, $3^{\prime} \ldots \ldots 1.50$

Less than five at double the rate per hundred, 


\section{Helenium}

pumilum. Yellow, August, 15"

Riverton Gem. Old Gold, Sept., Oct., 4'

Helianthella quinquenervis. Yellow,

$$
\text { Sept., 31/2' }
$$

uniflora. Yellow, Sept., 3'

Helianthemum croceum. Saffron, June,

$$
\text { July, 9" }
$$

Fire Ball. Red, July, Aug., 12"

Helianthus atrorubens. Yellow, Fall, 6'_-- 1.50

mollis grandiflorus. Yellow, Aug.,

Sept., $4^{\prime}$

orgyalis. Bright yellow, Oct., 6-8'_--- 1.50

Heliopsis excelsa. Deep yellow, Aug., 3'-- 2.50

Hemerocallis Apricot. Apricot color,

$$
\text { June, 2' }
$$

aurantiaca. Orange, June, July, $2 \frac{1}{2} \ldots$

dumortieri. Orange, June, 2' _-..--_-

florham. Golden yellow, June, $3^{\prime}$

Gold Dust. Indian yellow, June, 21/2'

luteola. Orange, June, 2' 
Hepatica acutiloba. Light blue, March, 4" $\begin{array}{r}\text { per } 10 \\ 1.50\end{array}$ per 100 triloba. Light blue, March, April, 4" --

Heuchera brizoides. Red, June, July, 2' --

Hibiscus Mallow Marvels. Mixed, July and

Mallow Marvels. Separate colors, Aug., 5'

Mallow Marvels. Giant Red, Aug., 5'_

15.00

moscheutos. Rose, June, July, 5'__._. 1.50

18.00

moscheutos crimson eye. White, red eye,

$$
\text { Aug., 5' }
$$

Hieracium aurantiacum. Orange, summer, $6^{\prime \prime}$

Hosta caerulea. Blue, July, 11/2 -..-- 1.50

lancifolia. Blue, July, 2'

12.00

marginata. White bordered, Aug., 2' --

1.80

ovata. Lavender, June, July, 1-2'_---

1.80

12.00

sieboldiana. Silvery foliage --_---_

1.80

sub-cordata grandifiora. White, Aug. 18"

2.20

undulata variegata. White foliage, $2^{\prime}$..

Hyacinthus candicans. White, Aug., 3'_..-

Hypericum calycinum. Yellow, July, Aug.,1'

moserianum. (See Shrubs).

Hyssopus officinalis. Purple, Aug. 18" _.- 1.80

15.00

15.00

15.00

18.00

15.00

15.00

18.00

Iberis gibraltarica. Delicate lilac, May, 11/2'

2.20

sempervirens. White, May, June, 8"

sempervirens Climax. White, May, 6" 2.00

15.00

18.00

15.00

18.00

sempervirens Little Gem.

White, April,

2.00

18.00

tenoreana. Purplish white, April, 6" 2.50

Incarvillea delavayi. Rosy purple, June,

$$
\text { July, 2' _...-. } 2.20
$$

Inula ensifolia. Yellow, July, Aug., 8" _- 1.50

helenium. Yellow, June, 11/2' _....-

royleana. Yellow, June, July, 2' _.- 1.50

Iris cristata. Light blue, May, June, 6" ${ }_{--} 1.50$ germanica. May, June, 11/2-2'.

Alcazar. Violet, purple falls___-_- 2.50

Aurea. Yellow _._._. 1.80

Blue Bird. Indigo blue _...-.-- 1.50 
Iris germanica.

\begin{tabular}{|c|c|c|}
\hline Celeste. Delicate blue & $\begin{array}{r}\text { per } 10 \\
1.50\end{array}$ & $\begin{array}{r}\text { per } 100 \\
12.00\end{array}$ \\
\hline Florentina. Pale blue -- & 1.50 & 12.00 \\
\hline Florentina alba. White & 1.50 & 12.00 \\
\hline Gracchus. Yellow and purple & 1.50 & 12.00 \\
\hline Her Majesty. Lilac pink & 1.50 & 12.00 \\
\hline Honorabilis. Yellow, brown falls -- & 1.50 & 12.00 \\
\hline King of Iris. Yellow, brown falls _- & 2.50 & 20.00 \\
\hline King Edward. Red violet & 1.50 & 12.00 \\
\hline Lavender Queen. Lavender -.--- & 1.50 。 & 12.00 \\
\hline Lohengrin. Lilac rose & 1.50 & 12.00 \\
\hline Loreley. Light yellow, blue falls -- & 1.50 & 12.00 \\
\hline Mad. Chereau. White, tinged blue & 1.50 & 12.00 \\
\hline Mad. Paquitte. Bright rose claret_- & 1.50 & .00 \\
\hline Midnight. Dark blue _-_- & 2.20 & 18.00 \\
\hline Mithras. Yellow, wine red falls --- & 1.80 & 15.00 \\
\hline Mrs. Allen Gray. Pale rose-mauve - & 1.50 & 12.00 \\
\hline Mrs. H. Darwin. Pure white & 1.50 & 12.00 \\
\hline Niebelungen. Fawn yellow --.--- & 1.80 & 15.00 \\
\hline Pallida Dalmatica. Lavender & 2.20 & 18 \\
\hline Pallida speciosa. Light blue & 1.50 & 12.00 \\
\hline Parisensis. Dark blue _-_- & 1.50 & 12.00 \\
\hline Princess Victoria Louise. Sulphur yel- & & \\
\hline $\mathrm{v}$, rich violet falls & 2.20 & 1800 \\
\hline Princess of Wales. Pearly white -- & 1.80 & 15.00 \\
\hline $\begin{array}{l}\text { Queen of Gypsies. Yellow standards, } \\
\text { maroon falls }\end{array}$ & 1.50 & .00 \\
\hline Rhein Nixe. White, violet falls & 2.20 & 18.00 \\
\hline Silver King. Silvery white & 1.50 & 12.00 \\
\hline Spectabilis. & 1.50 & 12.00 \\
\hline Trautlieb. Delicate pink & 1.80 & 15.00 \\
\hline Victorine. White, mottled blue -.-- & 1.80 & 15.00 \\
\hline
\end{tabular}

Gerda. Creamy yellow, darker falls.

Halfdan. Creamy white.

Ingeborg. Ivory white.

Helge. Light citron.

Walhalla. Light blue, purple falls.

kaempferi. Japanese Iris. July, 2-3' $2.50 \quad 18.00$ Antelope. Light lavender.

Less than five at double the rate per hundred. 
Iris kaempferi.

Aoigata. Light purple, with darker halo.

Chadai. Clear white, creamy standards.

Exquisite. Blue in light and dark shadings.

Furomon. White, purple shadings.

Gold Bound. White, yellow shadings.

Hannaoi. Gray, yellow blotches and blue veins.

Hinodeuzuru. White, blue shadings.

Idzumigawa. Gray, yellow blotches and blue veins

Komochiguma. Dark bluish purple.

Kumonoobi. Clear purple, white halo.

Kurokumo. Purple overlaid with dark blue, yellow blotches.

Manadzuru. White, yellow blotches.

Norma. Deep purple.

Onigashima. Brief violet purple.

Purple and Gold.

Royal. Mahogany red.

Shigano-uranami. Red lavender, white halo.

Uchiu. Crimson purple with few white veins.

Warai botei. Lavender blue, light blue halo.

new hybrids.

\begin{tabular}{|c|c|c|}
\hline & per 10 & 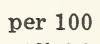 \\
\hline Mauve, violet falls & 1.80 & 15.00 \\
\hline Dorothea. Mauve, soft blue falls _- & 1.80 & 15.00 \\
\hline Isolene. Lilac pink, old rose falls_- & 2.50 & 18.00 \\
\hline Jeanne d'Arc. White & 1.80 & 15.00 \\
\hline $\begin{array}{l}\text { Tuee d'Orange. Slate gray with } \\
\text { bronze and purple falls }\end{array}$ & 1.80 & 15.00 \\
\hline Tamerlane. Light blue, darker falls & 2.50 & 18.00 \\
\hline pseudacorus. Yellow, June, $3^{\prime} \ldots$ & 1.50 & 12.00 \\
\hline pumila alba. Dwarf, White, April, 9" & 1.50 & 12.00 \\
\hline pumila caerulea. Dwf., Blue, April, 9" & 1.50 & 12.00 \\
\hline pumila violacea. Dwf., violet, April 9" & 1.50 & 12.00 \\
\hline siberica. Purplish blue, June, 3'_... & 1.20 & 10.00 \\
\hline iberica alba. White, & 1.20 & 10.00 \\
\hline tewart. Dwarf Yellov & 1.80 & 15.00 \\
\hline verna. Blue, May, Ju & 1.50 & 12.00 \\
\hline rsicolor. Blue, Ju & 1.50 & 12.00 \\
\hline
\end{tabular}

Kniphofia pfitzeri. Coral, Aug., Sept., 4' $2.20 \quad 20.00$

uvaria. Crimson to Yellow, Aug., Sept., 4' $2.20 \quad 18.00$ 
Lamium maculatum. Lavender, July, Aug., 8" 2.50

Lathyrus latifolius. Pink to Red, July, 6'_- 1.50

Lavandula officinalis. (Sweet Lavender). July, 2'

Lavatera cashmeriana. Pink, July, $3^{\prime} \ldots \ldots$ splendens. Rose, all summer, 11/2'-2.50 18.00

Liatris pycnostachya. Purple, Aug., Sept. 4' 1.50 scariosa. Deep purple, September, 2'_- 1.50 12.00 spicata. Purple, September, $3^{\prime} \ldots \ldots-\ldots$

Lilium auratum. (Gold Band Lily). White. with gold band, July, Aug., 3'_batemanniae. Salmon red, July $3^{\prime}$-- 3.00 canadense. Yellow to Red, June, July, 3' 1.50 25.00 candidum. White, June, $3^{\prime}$ elegans. Shades Yellow and Red, July, $2^{\prime}$ henryi. Yellow, July, 2' longiflorum giganteum. Waxy White, 2' pardalinum. Scarlet and Yellow, 2' -- 3.00 12.00 40.00 18.00 45.00 30.00 philadelphicum. Orange red, June, July, $3^{\prime}$

regale. White, Aug., 4' -.-_-_-_-_-speciosum album. White, Aug., $3^{\prime} \ldots--$ speciosum longiflorum. White, Aug. 3' speciosum melpomene. White, Aug., 3' speciosum rubrum. Pinkish red, Aug., 3' superbum. Orange, July, Aug., 5' -.-tigrinum. Orange spotted, Aug., 4' -umbellatum. Scarlet red, July, 2' -sinuatum roseum. Pink, Aug., 1' 12.00 tataricum. Purplish red, July, 1' 12.00

Linum narbonnense. Blue, June, July, 2' perenne. Blue, June, July, $1 \frac{1}{2} \mathbf{2}^{\prime}$ siphilitica. Blue, September, $3^{\prime}$ polyphyllus albus. White, June, July, 3' 2.50 chalcedonica. Scarlet, July, $3^{\prime} \ldots-\ldots-1.50$ 
Lychnis

coronata sieboldi. White, July, $1^{\prime}$-_ 1.80

floscuculi. Red, June, 11/2' ........

flosjovis. Pink, June, $1^{\prime}$

1.50

12.00

haageana. Scarlet, June, July, 1' -.--

1.50

12.00

viscaria splendens. Red, May, June, 1'

1.50

12.00

viscaria splendens fl.pl. Red, June, $1^{\prime}$

1.50

12.00

Lysimachia clethroides. White, July, Aug., 3'

1.80

15.00

nummularia. Yellow, June, Aug., 6"

1.50

12.00

Lythrum salicaria roseum. Rose, July, 4' .-

1.50

12.00

virgatum. Deep rose, July, Aug., 11/2'

1.50

12.00

Malva alcea. Rosy purple, July, Aug., 3'_--

1.50

moschata. Rose, July, Aug., 2'

Matricaria parthenoides. White, May, 1'--

12.00

Mentha piperita. Peppermint, Purple, 2'

12.00

Mertensia virginica. Purplish blue, March,

$$
\text { April, 2' }
$$

1.50

1.50

12.00

Miscanthus. (See Eulalia).

Mitchella repens. White shaded pink,

March, 4"

Monardi didyma. Red, July, Aug., 3' ---

didyma Cambridge. Scarlet, July, Aug., 3'

1.50

didyma pink. July, Aug., 3' _-_._-_- 2.20

12.00

12.00

didyma Sunset. Mahogany, July, Aug., 3 '

2.20

didyma splendens. Scarlet, July, Aug., $3^{\prime}$

1.50

18.00

18.00

didyına violacea. Violet, July, Aug., 3'

1.50

Myosotis alpestris. Blue, all summer, 8" --

1.50

12.00

12.00

alpestris alba. White, May, June, 8" --

1.50

palustris. Blue, April, May 6" -....-

1.50

Nepeta hederacea. Blue, May, 2" -..-_-. 1.50

hederacea variegata. Blue, May 2" -- 1.50

mussini. Blue, June, July 1' _-_...-- 1.80

12.00

12.00

12.00

12.00

12.00

15.00

Nierembergia rivularis. Creamy white,

summer, $4^{\prime \prime}$

Oenothera fruticosa youngi. Lemon, June,

$$
\text { July, 2' }
$$

12.00

lamarckiana. Yellow, July, Aug., 4' --

1.50

missouriensis. Yellow, July, Aug., 6" 1.80

speciosa. White, July, Aug., 11/2'

15.00

12.00

Pardanthus. (See Belamcanda).

Pachysandra terminalis. White, May, $3^{\prime \prime}$

2 year from pots_-_-_-_-_-_-_ 1.50 
Paeonia officinalis rosea. Rose pink _-_- $\quad 7.50$

per 100

officinalis rubra. Red _._._._. 7.50

60.00

60.00

sinensis. Strong plants, 3-5 eyes.

Candidissima. White, creamy center 5.00

45.00

Couronne d'Or. White, yellow center 7.50

60.00

Delacheii. Crimson _._. 5.00

45.00

Duchess de Nemours. Creamy white 7.50

60.00

Edulis. Deep rose _-_____-_-_ 5.00

45.00

Felix Crousse. Brilliant red _-.--- 10.00

90.00

Festiva alba. White _-__-_-_- 5.00

45.00

Festiva maxima. Finest early white 10.00

80.00

Gen. McMahon. Deep violet red_--- 10.00

Gigantea. Rose pink _._-_._-_ 12.50

90.00

Humeii. Deep rose

110.00

Jeanne d'Arc. Tender pink, center rosy white

45.00

La Tulip. Flesh pink, shading to white _-_._. 7.50

60.00

L'Eclatante. Dazzling red _..--_- 7.50

L'Esperance. Rose pink _..._... 7.50

L'Indispensible. Shell pink _-_-_-_ 7.50

Louis Van Houtte. Deep crimson -- 5.00

Livingstone. Soft pink _._._._. 12.50

Mad. de Galhau. Dark pink _-_- 7.50

Mad. de Verneville. Sulphur white, with some carmine

Mad. Lebon. Cherry _._._-_ 7.50

Marie Lemoine. Creamy white --_ 7.50

Modeste Guerin. Deep rose _._._- 5.00

Mons. Jules Elie. Pink with darker guard petals _._._._._. 12.50

60.00

60.00

60.00

60.00

45.00

110.00

60.00

60.00

60.00

60.00

45.00

110.00

Souv. de l'Exposition Universelle. Brillant cherry with silver reflex_--- 7.50

60.00

Triumph de Paris. Light pink, yellow center

60.00

single. Named colors, red, white, pink 16.00 tenuifolia fl. pl. Scarlet

Papaver bracteatum. Blood red, June, 2' -- 1.50

Less than five at double the rate per hundred. 
Papaver

Fire King. Red, June, 2' $\begin{array}{r}\text { per } 10 \\ 3.00\end{array}$

Goliath. Fire red, June, 2'__._.- 3.00

Queen Alexandra. Salmon, June, 2' 3.00

Princess Victoria Louise, Salmon, June, 2' 2.00

Pentstemon barbatus. Scarlet, July $3^{\prime}$ _-_ 1.50

12.00

digitalis. White, August, $3^{\prime}$

grandiflorus. Lilac blue, July, 3' -.--

1.80

hirsutus. Rosy purple July, Aug., 2 _- 1.50

15.00

2.50

$1.50 \quad 12.00$

Phalaris arundinacea variegata. Ribbon grass

Phlox amoena. Pink, May, 4" _._._._. 1.50

divaricata. Lavender, May, June, 1' --

maculata. Purplish red, May, June, 4'

1.50

ovata. Red, May, June, $1^{\prime} \ldots \ldots$

12.00 paniculata $2-3^{\prime}$

Aloise Louise. Lilac _._._._._._. 1.50

Antonin Mercie. Lilac, white center_-

Athis. Salmon pink -...-_..--.--

1.50

1.50

B. Compte. Rich French purple_-

Bridesmaid. White, red eye _....-

2.20

15.00

Cameron. Shell pink -...........-

Caran de Ache. Bright carmine rose 1.50

Champs. Elysees. Rich purplish crimson

1.80

Coquelicot. Orange scarlet _..._._. 1.80

Etna. Scarlet _-_-_____-_-_-_ 2.20

1.50

1.80

12.00

12.00

12.00

18.00

12.00

15.00

12.00

Eiffel Tower. A beautiful pink -..-

Elizabeth Campbell. Salmon pink_-

Evelyn. Salmon rose

Fernand Cortez. Coppery red -...--

Frau Anton Buchner. White -..---

Frau Von Lassburg. White -...--

G. A. Strohlein. Orange scarlet, red

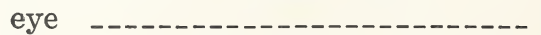

Gefion. Peach blossom pink, rose eye

Grideur. Pink, crimson center -.--

Henri Murgher. White, magenta eye

2.20

2.20

3.00

1.80

1.50

1.80

15.00

15.00

18.00

18.00

18.00

25.00

15.00

12.00

J. H. Slocum. Red

2.20

18.00

1.80

15.00

1.80

15.00

1.80

15.00

1.80

15.00

Johnson's Favorite. Salmon rose _... 1.80

15.00

Less than five at double the rate per hundred. 
Phlox paniculata.

per 10

Mad. Benzanson. Crimson _..._._. 1.80

per 100

Mad. Paul Dutrie. Soft pink _..-.-

1.80

15.00

Malmaison. Salmon, red eye _....-

3.00

15.00

Maid Marian. Soft lavender _......

3.00

25.00

Mrs. Jenkins. Pure white_._._._.

1.50

Mrs. Ingalls. Shell pink _._._. 1.50

25.00

Mrs. Milly van Hoboken. Soft pink

2.20

M. P. Langier. Red _._._._. 1.80

12.00

Miss Lingard. White

1.50

Pantheon. Deep salmon rose _-_--- 1.50

12.00

Peachblossom. Shell pink_._._._.

1.50

Pres. Poincare. White rose eye_--- 1.80

18.00

Rheinlander. Salmon pink, claret eye

1.80

Richard Wallace. White, crimson eye 1.50

15.00

Rynstroom. Bright crimson pink_--- 1.80

12.00

12.00

12.00

15.00

15.00

12.00

R. P. Struthers. Carmine, claret red

eye _-_-_-_-_-_-_-_-_-_-_-_ 1.80

Siebold. Orange scarlet _._-_._-_ 1.80

15.00

Sir Edward Landseer. Bright crimson

Special French. Soft pink _._.---

1.80

Tapis Blanc. Dwarf, white _....-

1.80

1.50

Thor. Deep salmon pink_._...-

Vald Jensen. Salmon red, white eye

2.20

3.00

White Le Mahdi. White _._-_-_-_- 1.80

Widar. Light reddish violet, white eye 1.80

reptans. Lilac, May, 6-12" _._._._. 1.50

stellaria. Creeping, May, 4" _._._.- 1.50

subulata alba. White, April, May, 4" 1.50

15.00

15.00

15.00

15.00

12.00

18.00

25.00

15.00

15.00

12.00

12.00

subulata lilacina. Light blue, April,

$$
\text { May, 4" -_._-_._- } 1.80
$$

12.00

subulata moerheimi. Carmine pink,

$$
\text { April, May, 4" _._-_._-_._. } 1.80
$$

15.00

subulata nelsoni. White, April, May, 4" 1.80

subulata rosea. Pink, April, May, 4" -- 1.50

subulata The Bride. White, red center,

$$
\text { Apr., May, 4" -_-_-_-_-_-_- } 1.80
$$

15.00

12.00

Physalis francheti. Red pods, Oct., 2' ---- 1.50

12.00

12.00

virginiana alba. White, August, 3' -- 1.50

12.00

Platycoden grandiflorum. Blue, summer, 2' 1.50 grandiflorum album. White, summer, 2' 1.50

mariesi. Deep blue, summer, 1' _-.- 1.50

12.00

Less than five at double the rate per hundred. 
Plumbago larpentae. (See Ceratostigma).

per 10

per 100

Polemonium caeruleum. Deep blue, June, July, $1 \frac{1}{2}$

caeruleum album. White, June, July, $11 / 2^{\prime}$

reptans. Blue, May, June, 6"

richardsoni. Sky blue, May, June, 6" 1.50

Polygonum amplexicaule. Red, Sept., 5' -compactum. White, Aug., Sept., 11/2' cuspidatum. White, Aug.s Sept., 11/2'

oxyphyllum. Creamy white, Sept., 3'

Potentilla hybrida fl. pl. Mixed, June,

$$
\text { July, 2' }
$$

hyb. Gibson's Scarlet. Red, July,

$$
\text { Aug., 2' }
$$

hyb. Mons. Rouillard. Crimson, July,

$$
\text { Aug. 2' }
$$

nepalensis. Showy red, May, June, 2'

rupestris alba. White, June, July, 2'--

Primula acaulis. Yellow, May, 9" -..-_-_cashmeriana. White, May, 8" -...-_-. 1.80 japonica. Crimson, May 9" -........pulverulenta. Yellow, May, 8" -...-veris. Yellow, April, May, 9"-.....--

\section{roseum James Kelway.}

$$
\text { Red, May, June, 1' }
$$

uliginosum. White, September, 5'

Ranunculus acris fl. pl. Dbl. Buttercup,

$$
\text { June, } 1^{\prime}
$$

Rosemarinus officinalis. Light blue, April, 4" 1.80

Rudbeckia Autumn Glory. Yellow, Aug.,

Sept., $6^{\prime}$

hirta. Yellow, Aug., Sept., 3'

laciniata. (Golden Glow) Yellow, Aug., 6' subtomentosa. Lemon yellow, August, 
per 10

Ruta graveolens. Yellow, all summer, 21/2' 2.50

22.00

Sagina subulata. White, July, Aug., 3" -- 2.00

15.00

Salvia azurea grandiflora. Blue, Aug., 6' 6 -- 1.50

12.00

argentea. Pinkish White, June, 3' -.--

1.50

farinacea. Blúe, July, 2-3' _......-.- 1.50

12.00

pratensis. Deep blue, Aug., Sept., 3' --

1.50

12.00

turkestanica. White, tinted pink, Aug., 2'

1.80

12.00

uliginosa. Blue, August, 2'

1.50

15.00

Sanguinaria canadensis. White, April, 8" -- 1.50

12.00

Saponaria ocymoides. Pink, summer, 9" .--

1.50

12.00

ocymoides alba

1.80

12.00

Saxifraga cordifolia. Rosy purple, April, May 1' -...-_-_- 3.00

15.00

crassifolia. Rosy pink, April, 1' -..grandiflora. Pink, April, 1' -...-.-lingulata rosea. Pink, April, 1' _..lingulata leichtlini. Rose, Apr., 1' -.-purpurea. Rosy purple, April, 1' -.--

3.00

25.00

25.00

3.00

3.00

3.00

3.00

25.00

25.00

25.00

25.00

Scabiosa caucasica. Lavender, all summer, $1^{\prime}$

2.50 japonica. Lavender, Aug., Sept., 18"

2.20

18.00

Sedum acre. Yellow, June, July, 4" -.....

1.50

album. White, July, $4^{\prime \prime}$-........-.

1.50

ewersi. Pink, Aug., Sept., 6" _.......-

kamtschaticum. Yellow, July, 6" -..-

1.50

1.50

maximowiczi. Yellow, July, Aug., 1'

1.50

sarmentosum. Yellow, July, 3" --.-

1.50

sexangulare. Yellow, June, July, 6" --

1.50

sieboldi. Pink, July, August, 1' ...-

1.80

spectabile. Pink, Aug., Sept., 11/2' --

1.50

spectabile Brilliant. Crimson, Sept., 11/2'

1.50

stoloniferum. Crimson, July, Aug., 6" 1.50

12.00

12.00

12.00

12.00

12.00

12.00

12.00

15.00

12.00

12.00

stoloniferum coccineum. Crimson,

Aug., 6" _..._-_._- 1.50

12.00

12.00

18.00

Sempervivum arachnoideum. Red, June, 4"

2.20

arenarium. Yellow, July, 6"

18.00

tectorum violaceum. Violet red, June, 4"

2.20

18.00

18.00

Senecio clivorum. Yellow, Aug., Sept., 18" 2.20

Sidalcea candida. White, July, Aug., 3' -- 1.50

12.00

Rose Queen. Rose pink, July, Aug., 4' 2.20

18.00

Silene orientalis. Pink, July, 2' _........- 1.50

12.00

schafta. Bright pink, July, 6"

12.00

Less than five at dowhle the rate per hundred. 
per 10

Silphium perfoliatum. Yellow, July, 6' - 1.50

12.00

Smilacina racemosa. White, April, 2-3' _- 1.50

12.00

Solidago canadensis. Yellow, Fall, 4-5' - 1.50

12.00

rigida. Yellow, Fall, 3-4' _-_-_-_-_ 1.50

12.00

shorti. Yellow, Fall, 4' _........ 2.50

22.00

Spirea aruncus. White, June, July, 3-5'_- 1.80

15.00

chinensis. Silvery pink, June, July, 2' 1.80

15.00

eximea. Pink, June, July, 2' _.....- 3.50

30.00

filipendula. Single, White, June,

July, 1'

15.00

filipendula fl. pl. White, June, July, 1' 2.20

18.00

lobata. Pink, July, 4' _._._._._ 2.20

18.00

palmata. Rosy crimson, June, July, 2' 1.80

15.00

ulmaria fl. pl. White, June, 3-4'_._.- 1.80

15.00

venusta magnifica. Deep pink, July $3^{\prime} \quad 3.00$

25.00

Stachys lanata. Purple, June, July, 11/2' - 1.50

12.00

grandiflora superba. Rose, July, 2' _- 1.50

12.00

Statice. (See Limonium).

Stellaria holostea. White, May, June, 11/2' 1.50

12.00

Stenanthium robustum. White, August, 3' 2.50

Stokesia laevis. Lavender, Aug., Sept., 1' 1.50

laevis alba. White, Aug., Sept, $1^{\prime}$-_-_ 1.80

12.00

15.00

Teucrium chamaedrys. Rose, August, 1' -- 1.50

12.00

Thalictrum adiantifolium. Yellow, June, 4' 1.80

aquilegifolium. White, June, 5' ..... 1.80

15.00

aquilegifolium purpureum. Purple,

June, 3'

baicalens. Yellow, June, 4' $4 . .80$

dipterocarpum. Lilac, June, $4^{\prime}$ - --2.50

glaucum. Golden-yellow, June, $4^{\prime} \ldots . .-2.20$

15.00

Thermopsis caroliniana. Yellow, June, 6' 1.50

mollis. Yellow, June, July, 2-3' _-.- 1.50

15.00

22.00

18.00

12.00

12.00

Thymus serpyllum. White, June, 4" $\ldots--1.50$

12.00

serpyllum citriodorus. Purple, June,

July, 3-5" _..-_-_-_.-. 1.50

12.00

serpyllum coccineus. Scarlet, June, 4" 1.50

12.00

serpyllum lanuginosus. Rosy purple,

June, July, 5" _._._._._._. 1.50

vulgaris. Lilac, June, July $2^{\prime} \ldots \ldots 1.50$

Tess than five at double the rate per hundrea. 
Tiarella cordifolia. Creamy white, June, 8" 1.50

Tritoma. (See Kniphofia).

Trollius asiaticus. Rich orange July, Aug., 2' _._. 3.50

30.00 europeus. Citron yellow, July, Aug., 1'

Valeriana officinalis. Rose, June, July, 5' officinalis alba. White, all summer, 5'

Verbascum olympicum. Yellow, July, Aug., 5'

1.80 phoeniceum. Various, May, June, 3' -- 1.80 elegantissima. Blue, July, Aug., 2' -..incana. Pale blue, July, Sept., 11/2' -longifolia subsessilis. Blue, Aug.,

pectinata rosea. Pink, May, June, 6" --

pulchella. Blue, May, $1^{\prime}$

rupestris. Blue, June, 6"

spicata. Blue, July, Aug., 2'

cornuta Admiration. Purple, all

cornuta alba, type. White, all summer, $6^{\prime \prime}$

cornuta Blue Perfection. Blue, all summer, $6^{\prime \prime}$

cornuta G. Wermig. Violet, all summer, $6^{\prime \prime}$

cornuta Lutea Splendens. Yellow, all summer, $6^{\prime \prime}$

cornuta Mauve Queen. Mauve, all summer, 6"

cornuta Papilio. Violet all summer $6^{\prime \prime}$ 
Viola

\begin{tabular}{|c|c|c|}
\hline gracilis. Deep violet, sum & $\begin{array}{r}\text { per } 10 \\
1.80\end{array}$ & $\begin{array}{r}\text { per } 100 \\
15.00\end{array}$ \\
\hline odorata. Blue, April, May, $6^{\prime \prime}$ & 1.50 & 12.00 \\
\hline odorata Gov. Herrick. Blue, May, 6" & 2.20 & 18.00 \\
\hline odorata Princess of Wales. Violet, May, 6" & 2.20 & 18.00 \\
\hline wellsiana. Various, all & 2.20 & 18.00 \\
\hline
\end{tabular}

Yucca filamentosa. White, June, July, $7^{\prime}$

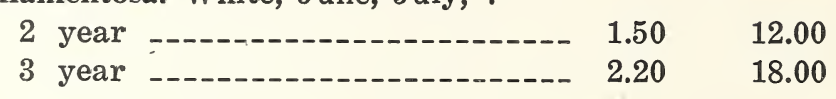

Less than five at double the rate per hundred.

\section{Hardy Ferns}

per 10 per 100

Adiantum pedatum. Maiden Hair Fern $\quad .25 \quad 1.80 \quad 12.00$

Asplenium Felix Faemina. Lady Fern. $\quad .25 .1 .80 \quad 12.00$

Dennstedtia punctilobula. Hay-scented

Fern -

Dryopteris spinulosum. Wood Fern $-\begin{array}{rrr}.25 & 1.80 & 12.00\end{array}$

Dryopteris thelypteris. Shield Fern $\quad$-- $\quad \begin{array}{llll}.25 & 1.80 & 12.00\end{array}$

Onoclea sensibilis. Sensitive Fern ---- $\quad .25 \quad 1.80 \quad 12.00$

$\begin{array}{lllll}\text { Onoclea Struthiopteris. Ostrich Fern } & .25 & 1.80 & 12.00\end{array}$

Osmunda cinnamonea. Cinnamon

Fern -

regalis. Royal Fern__-_-_-_-_-_. $.251 .80 \quad 12.00$

Polystichum acrostichoides. Christmas Ferm 





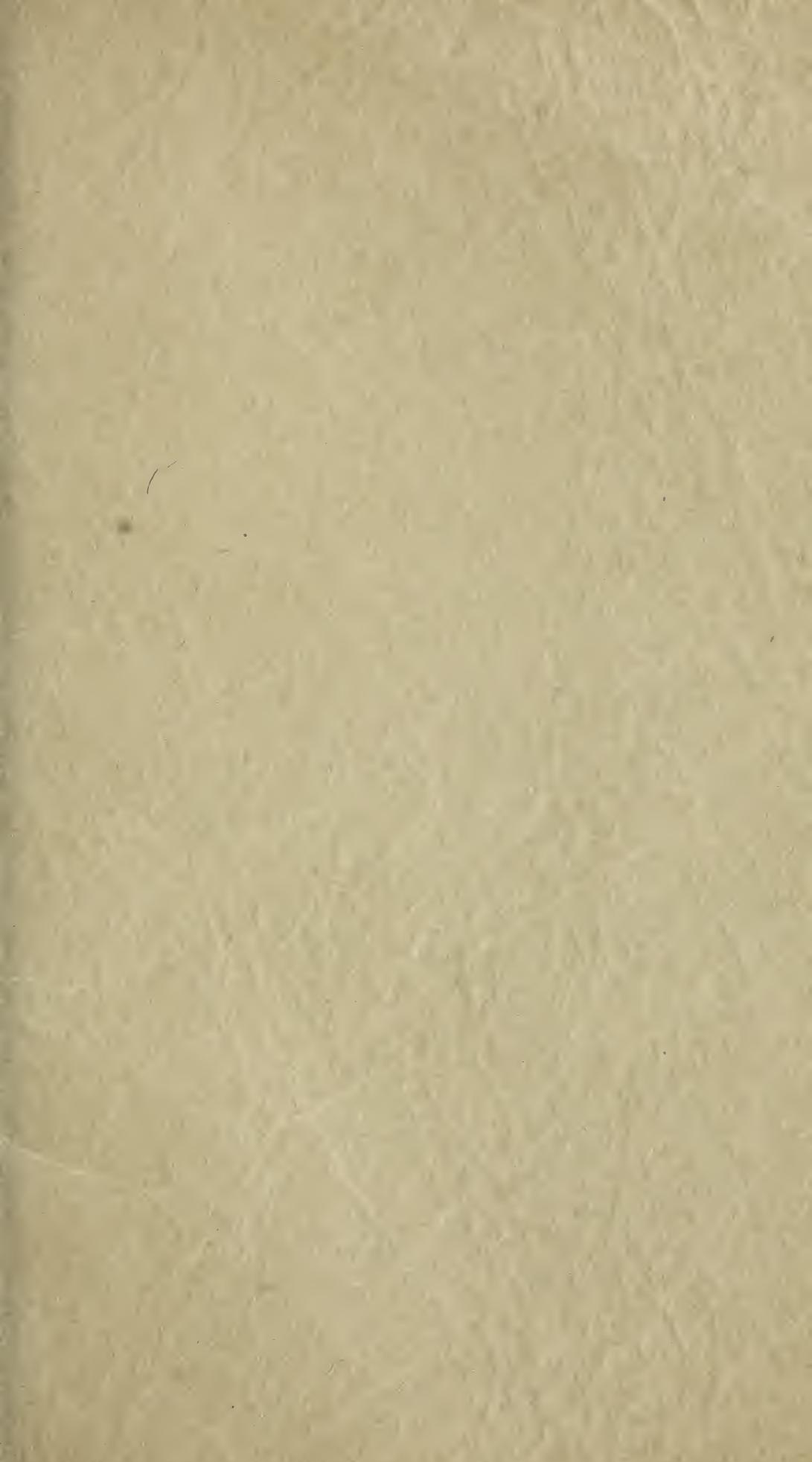


